\title{
Porovnanie digitálnych a klasických archeologických dokumentačných metód na príklade stredovekých šachových figúrok
}

\section{Digital and analogue documentation approaches in archaelogy: Chess pieces as a case study}

\author{
Natália Kosmelová / Vojtěch Nosek
}

\begin{abstract}
Abstrakt
Článok vychádza z bakalárskej práce Natálie Kosmelovej (2018). Prináša štandardnú súčasnú dokumentáciu drobných archeologických predmetov, rovnako tak popisuje dokumentáciu súboru pomocou vybraných 3D záznamových médií a vyhodnocuje možný prínos tohto druhu dokumentácie pre vedecké a prezentačne účely. Zároveň sú v článku komparované bežné aj inovatívne techniky. Záverom článku sú demonštrované možnosti publikácie, vizualizácie a prezentácie kultúrneho dedičstva. Skúmanú problematiku doplňajú vyhotovené 3D modely.

\section{Kl'účové slová}

Šachové figúrky, 3D fotogrametria, obrazovo-orientované modelovanie, 3D skenovanie, vrcholný stredovek, prezentácia archeologických nálezov, vizualizácia reality

Abstract

The article is based on the bachelor thesis of Natália Kosmelová (2018). The article describes the standard documentation of small archaeological finds used nowadays and also describes the documentation of the collections by chosen 3D data recorders. At the same time it evaluates the possible contribution of this type of documentation for scientific and presentational purposes. In the article innovate and routine techniques are simultaneously compared. In conclusion, the possibilities of publications, visualizations and presentation of cultural heritage are demonstrated. The researched topic is supplemented by finished 3D models.
\end{abstract}

\section{Key words}

Chess pieces, 3D photogrammetry, Image-based modelling, 3D scanning, High Middle Ages, presentation of archaeological finds, reality visualization 


\section{1. Úvod}

Pri každom vedeckom výskume zistujeme, overujeme, kontrolujeme a vytvárame nové závery. Výsledkom sú nové poznatky a hlavne nové spôsoby skúmania, ktoré umožňujú vedecký posun. $\mathrm{S}$ určitostou môžeme povedat', že s vyvíjajúcou sa vedou sa vyvíja aj jej metodológia, a teda spôsob skúmania (Kuna 2004, 11). V dôsledku kladenia vyššieho zretela na nedeštruktívne metódy v archeológií, v kombinácií so stále väčšou dostupnostou výpočtovej techniky, rastie popularita trojrozmernej dokumentácie a tiež rozvoj inovatívnych dokumentačných techník (napr. Gilboa - Kolomenkin - Tal - Shimshoni 2013). Tieto by sme v predkladanej štúdií priblížili a následne aj popísali na vlastných skúsenostiach, pretože pre budovanie metodológie sú vždy najdôležitejšie vlastné skúsenosti a hlavne skúsenosti odborníkov, ktorí danú disciplínu opakovane uskutočňujú (Neustupný 2007, 17).

Hlavným cielom článku je snaha zhrnút problematiku využívania vybraných dokumentačných techník (kresba, fotografia a trojrozmerný záznam získaný pomocou 3D fotogrametrie a 3D skenera) v našom odbore $s$ ich možnými prínosmi a úskaliami. Vybrané dokumentačné techniky sú testované a porovnávané na súbore stredovekých šachových figúrok.

Metódy nie sú porovnané len medzi sebou navzájom, ale komparované sú aj výsledky jednotlivých inovatívnych metód s odstupom času za cielom poukázania na rýchlo vyvíjajúce sa technológie s vyzdvihnutím ich prínosu pre náš odbor. ${ }^{1}$ Možný prínos tohto druhu dokumentácie je vyhodnotený ako pre vedecké tak aj reprezentatívne účely.

Výsledné priestorové modely, zhotovené pomocou 3D fotogrametrie, sú uložené vo formáte .obj na online platforme Sketchfab (https:// sketchfab.com/eNKa44), a sú taktiež súčastou bakalárskej diplomovej práce (Kosmelová 2018). Záverom sú na príklade digitalizovaného sú- boru artefaktov a inšpiratívnych projektov demonštrované možnosti publikácie, vizualizácie a prezentácie kultúrneho dedičstva.

\section{Práca $v$ ateliéroch a obecný úvod do problematiky porovnáva- ných dokumentačných metód}

Vel'ká čast̉ výskumu bola realizovaná v ateliéroch Masarykovej univerzity, a to konkrétne v 3D ateliéri Ústavu archeologie a muzeologie na Filozofickej fakulte a v Laboratóriu morfológie a forenznej antropológie na Př́rodovědeckej fakulte MU.

Práca v 3D ateliéri zahŕňala vyhotovenie fotografických snímok figúrok, ich úpravu, kalibráciu, testovanie nastavenia programu Agisoft PhotoScan (spoločnosti Agisoft), a samotnú tvorbu modelov. Práca v Laboratóriu morfológie a forenznej antropológie spočívala vo vyhotovení trojrozmerného záznamu šachových figúrok pomocou 3D skenera NextEngine a programu NextEngine ScanStudio (spoločnosti NextEngine). Finálna tlač figúrok bola uskutočnená na Ústavě výpočetní techniky MU.

Zaoberali sme sa dokumentáciou v zmysle vizuálneho a priestorového zachytenia podoby archeologických artefaktov, a to čo najpresnejším, najdetailnejším a najprehladnejším spôsobom. V súčasnosti existuje v porovnaní s minulým storočím pochopitelne viac spôsobov vizuálneho záznamu a tak vznikajú v priebehu archeologického bádania otázky kedy a ktorú metódu uplatnit, aby bádatel' dosiahol čo najrelevantnejších výsledkov. K dnes už klasickým dokumentačným metódam, ako je kresba a fotografia, sme pre potreby vzájomného porovnávania v tomto článku pridali trojrozmerné záznamy vyhotovené pomocou 3D fotogrametrie a 3D skenera, ako zástupcov novej generácie dokumentačných techník a uchovávania informácií o artefaktoch a archeologických situáciách. 
Kresba predstavuje najstaršiu dokumentačnú techniku vôbec. Do 19. storočia však mala skôr umelecký charakter, kresby boli štylizované, bolo na nich zachytené množstvo nepodstatných informácií ako pozadie, odlesky a podobne (Griffiths - Jenner - Wilson 1990, 6). V dnešnej dobe sa kresebná dokumentácia snaží úplne eliminovat umeleckost̉ a blíži sa technickej kresbe s cielom priniest’ čo najviac relevantných a presných informácií.

Medzi nevýhody kresebnej dokumentácie patrí fakt, že pri jej tvorbe dochádza ku ovplyvňovaniu a skresleniu reality samotným dokumentátorom, ktorý či už chcene alebo nechcene vnáša do kresby svoju interpretáciu, subjektívny názor a kladie dôraz na rôzne aspekty predmetu. V minulosti bolo považované za výhodu možnost’ potlačenia určitých vlastnosti predmetu alebo naopak ich vyzdvihnutie a zvýraznenie. Avšak v momente, kedy je artefakt nenávratne poškodený, alebo stratený a možnost' ho d’alej študovat je len z dochovanej kresebnej dokumentácie, sú možnosti skutočného odborného štúdia, výskumu a nových interpretácií takmer znemožnené.

Výsledná kresba býva do vel'kej miery ovplyvnená schopnostami a zručnostou dokumentátora verne zaznamenat realitu. Nie každý zvláda presné technické kreslenie a vd’aka tomu aj inak schopný dokumentátor nemusí dokázat terénnu situáciu alebo artefakt zdokumentovat natol'ko presne, aby výsledná kresba zodpovedala realite. Takmer vždy tak ide skôr len o schematizovanú vizualizáciu, ktorá je síce pre dokumentáciu predmetu prínosná, no nemala by však hrat’ v jeho zaznamenaní pre d'alšie generácie hlavnú úlohu. Kresebná dokumentácia však nie je ovplyvňovaná len schopnostami a prístupom dokumentátora, ale aj jeho vybavením, podmienkami, časovými možnostami, poveternostnými vplyvmi a d’alším. Ako d’alšie mínus je možné uviest', že jeden človek aj po niekol'kých pokusoch nikdy nenakreslí jednu terénu situá- ciu či artefakt celkom totožne. V tom aspekte sa táto metóda záznamu líši od fotodokumentácie, kedy fotoaparátom môžeme pri dodržaní pravidiel docielit niekol'ko relatívne totožných a minimálne skreslených fotografií (napr. Frouz - Králik 2015).

Fotodokumentácia, ako druhý porovnávaný záznam reality, sa rozvíjala od 19. stor., kedy bola v roku 1839 objavená fotografia, aj ked' prvé experimenty prebehli o niekol'ko rokov skôr (Skopec 1956, 10). Od svojich počiatkov, kedy bolo vyhotovenie fotografie pomerne náročné a tento úkon vyžadoval znalost’ chémie a podobných hlavne technických disciplín, prekonala fotografia výrazný pokrok, a dnes patrí k neodmyslitelným dokumentačným technikám v mnohých vedných odboroch vrátane archeológie.

Dnešné variabilné a prispôsobitelné technické prostriedky fotografie umožňujú významne podporit terminologický popis archeologickej situácie alebo artefaktu prostredníctvom farebného a priestor ponímajúceho obrazového záznamu. Vzhladom k tomu, že náš spôsob poznávania je výrazne spojený so zrakovými vnemami farebnej a priestorovej povahy, obrazová dokumentácia predstavuje vel'mi podstatný prvok v orientácií v dokumentovaných javoch (Frouz - Králik 2015, 5). Oproti kresebnej dokumentácií má tú výhodu, že nám dokáže poskytnút objektívnejší a presnejší obraz daného artefaktu alebo danej nálezovej situácie. Presné zachytenie objektu však dosiahneme len s dodržaním všetkých pravidiel pri nastavení prístroja, svetla, finálnej úpravy a podobne. Rovnako ako pri iných spôsoboch dokumentácie spojených s rozvojom elektronických médií je nutné zavedenie medziodborového dialógu. Aby bola fotografia prínosná, musí rešpektovat potreby archeológie, ktoré sa dajú bez archeologického vzdelania a znalosti zmyslu technickej a štandardizovanej fotografie len odhadovat. Toto pravidlo platí aj obrátene, kedy pri rešpektovaní 
archeológovi často neznámych fotografických pravidiel a postupov, môže fotografia predstavovat omnoho efektívnejší a archeologicky hodnotnejší nástroj, než za aký sa obyčajne považuje (Frouz - Králik 2015, 5).

Mohlo by sa zdat, že na rozdiel od kresebnej dokumentácie nedochádza k žiadnemu skresleniu reality. Povahu fotografie ale tiež ovplyvňuje fotograf, a to svojimi technickými schopnostami a zručnostami, svojim osobným prístupom a odborným pohladom na tému, ktorá je fotograficky spracovaná. Fotografia síce zachytáva povrchovú textúru, farebnost’ a je možné vyhotovit niekol'ko pohladov, no možná nevýhoda fotodokumentácie spočíva $\mathrm{v}$ nemožnosti vyhotovenia rezov predmetov, ktoré vytvárajú lepšiu predstavu o tvare predmetu. Mnoho bádatelov v archeológií stále nepovažuje fotografiu za alternatívu ku kresebnej dokumentácií kvôli rôznym formám deformácie obrazu. K týmto deformáciám patrí hlavne použitie objektívov rôznych ohniskových vzdialeností a iné posuny, ktoré vyplývajú z optických a záznamových vlastností fotografickej techniky (Frouz - Králik $2015,7)$. Správna fotografia by mala byt doplnená tzv. objektivizačnými informačnými prvkami (Frouz - Králik 2015, 8), ktoré umožňujú lepšie pochopenie fotografického záznamu. Sú to informácie, ktoré sú previazané so snímkou, a ktoré nám ju pomáhajú presnejšie definovat, alebo určit. Z vyššie popísaných dôvodov tak môžeme konštatovat', že fotografický záznam je pre archeológiu neodmyslitelným spôsobom dokumentácie a aj nad’alej bude hrat' v archeológií významnú úlohu.

Medzi jednu z najmladších metód využívanú pre záznam archeologických objektov a situácií patrí 3D fotogrametria. Môžeme povedat', že ide o meračskú metódu umožňujúcu modelovanie v 3D priestore s využitím 2D snímok (Kasser - Egels 2002, 1). Virtuálne trojrozmerné modely predstavujú nástroj, ktorým môžeme uchopit priestorové aj formálne vlastnosti archeologic- kých prameňov v ich úplnom celku (Švejnoha 2010, 109).

Popularita a využitia trojrozmerných dát spočíva hlavne v jasnej a jednoduchej prezentácií výsledkov z archeologických výskumov širšej verejnosti, ktorá nemá predstavivost̉ vycvičenú dlhým pôsobením v odbore. Zároveň narastá aj kvalita grafických výstupov pre vnútorne potreby odboru (Malina 2008, 221). Aj napriek možnému širokému využitiu v archeológii, napr. pri dokumentácií malých hnutel'ných predmetov, nehnutel'ných objektov až po celkovú virtuálnu rekonštrukciu historickej krajiny (napr. Karasik - Smilansky 2008; Gruen 2008), nachádzame $\mathrm{v}$ tomto odbore trojrozmerné modely, aj kvôli dôvodom uvedeným d’alej, stále pomerne málo.

Dosiahnutie dostatočne vysokej presnosti a rozlíšenia modelu je vo velkej miere závisle na metóde merania podkladov v ateliéri alebo v teréne a následnom spracovaní na počítači. Tu sa kvalita výstupu odvíja od typu vybraného softvéru a tým aj vo zvolenom spôsobe postprocessingu. V súčasnej dobe existuje stále sa zväčšujúce množstvo softvérov (uvádzame len príklady najpoužívanejších), ktoré môžeme rozlísit na dva základne typy:

1. fungujúce na osobnom počitači (Agisoft PhotoScan, PhotoModeler, Pix4D), ktoré počítajú modely priamo na počítači užívatel’a. Ich vel'kou výhodou je možnost' zasahovat do každého kroku modelovania a ovplyvňovat ho podla potreby a preferencie. Nevýhodou je vel'ká náročnost’ na hardvérovú výbavu počítača, s ktorým sa pracuje,

2. tie, ktoré fungujú na báze Cloud computingu (Recap, Agisoft Metashape). Majú však nevýhodu v nemožnosti ovplyvnit tvorbu modelu. Ich potencionálny problém spočíva tiež $\mathrm{v}$ autorských právach k 3D modelom, ktoré podla License Agreementu získavajú spoločnosti prevádzkujúce Cloud computing službu. ${ }^{2}$ 
Oba uvedené typy programov sa potom ešte delia na platené (Agisoft PhotoScan) a na neplatené (Zephyr). ${ }^{3}$

Špeciálnym typom programov sú tie, ktoré slúžia predovšetkým k editácií zhotovených modelov. Tie sa opät delia na komerčné (3D Studio MAX, Rhinoceros 3D) a na volne stiahnutelné (MeshLab, Blender).

Medzi klady trojrozmernej fotogrametrie patrí virtuálne meranie objektu, kedy môžeme vytvorit rezy, zmerat' objem, plochu a všetky proporcie bez fyzického dotyku a hlavne akejkolvek deštrukcie skúmaného predmetu. Do využitia trojrozmerných modelov spadá tiež prezentácia vývoja objektov, kde pracujeme $\mathrm{s}$ viacerými možnostami interpretácie jedného objektu a ktoré sú vizuálne atraktívne. Rovnako tak je častá potreba prekonat fragmentárnost’ a objekt zobrazit v úplnosti. ${ }^{4}$ Vel'ká výhoda tejto metódy je jej relatívna časová nenáročnost’ v teréne, kde sa namiesto zdĺhavého kreslenia terénnej situácie alebo objektov vyhotovia len fotografie pre následný 3D model.

Medzi potencionálne nevýhody môže patrit zachytenie povrchu alebo hrúbky daného predmetu či situácie. Je preto nutné prispôsobit postup pri vyhotovovaní snímok konkrétnym potrebám.

Je tiež potrebné zmienit, že pri vyhotovovaní trojrozmerných modelov je dôležitý kvalitný hardvér (notebook aj fotoaparát) a tiež softvér, ktorý môže byṫ finančne náročnejší, pokial’ nejde o frivér. Oproti klasickým 3D skenerom je táto čiastka ale zanedbatelná a únosná.

Ako možné negatívum, sa podla nevýhody spojené s povrchom a hrúbkou predmetu.

Posledná metóda, ktorá bola porovnávaná je 3D skenovanie. 3D skenery sú zariadenia, ktoré dokážu preniesţ priestorovú informáciu skutočného predmetu do virtuálneho trojrozmerného modelu. Fungujú na princípe zhromažd'ovania údajov o tvare a vzhlade snímaného predmetu pomocou rôznych technológií (napr. optické skenovanie, CT skenovanie alebo laserové 3D skenovanie).

Technológia 3D skenovania bola pôvodne vyvinutá primárne pre priemyselné využitie a v archeológií je síce relatívne populárna, no pre svoju náročnost́ na financie a na obsluhu nie je masovo rozšírená. Ide o digitálnu technológiu umožňujúcu vytvorit priestorový model trojrozmerného objektu. Existujú rôzne typy 3D skenerov, ktoré fungujú na rôznych princípoch snímacej technológie. Ďalej je možné ich delit na bezkontaktné a dotykové. Ako už z názvu vyplýva, bezkontaktné 3D skenery budú informácie o objekte získavat bez kontaktu s predmetom a teda optickým spôsobom. Optické metódy môžeme d’alej rozdelit podla toho, či na objekt niečo vysielajú alebo nie $(\mathrm{Na}$ vrátil 2016, 31). Tieto metódy sa d’alej delia na aktívne a pasívne, pričom aktívne sa opät delia podla toho, aká fyzikálna vlastnoste je využitá pre výpočet modelu. Je to napríklad metóda triangulácie, ktorá dokáže vypočítat priestorový bod na základe známeho uhlu medzi projektorom a snímačom, známej vzdialenosti projektora od snímača a známej polohy meraného bodu na snímači (Navrátil 2016, 31). Jednou z najpouživanejších metód je Time of Flight, skrátene ToF, a ako už názov vypovedá je založená na meraní času odrazeného vyslaného lúča od objektu a jeho vrátenie spät na snímač. Používa sa tiež laserové skenovanie, avšak v súčasnej dobe sú tieto 3D skenery pri dokumentácií kultúrneho dedičstva na ústupe z dôvodu vysokej ceny a nedostatkov, ktoré sú v porovnaní s inými 3D dokumentačnými metódami príliš obmedzujúce (Nosek 2014, 6).

Vzniknuté 3D modely sú nepochybne vel'kým pokrokom $\mathrm{v}$ archeologickom spôsobe dokumentácie a prezentácie artefaktov. Sú vhodné k využitiu v online múzejných katalógoch, ako učebné pomôcky a $\mathrm{v}$ neposlednom rade sú obrovským prínosom pri modernizácií a popularizácií nielen múzeí. Popularita takéhoto 
druhu dokumentácie rastie hlavne pre svoju nedeštruktívnu povahu a relatívne lahký prístup k zdigitalizovanému artefaktu. Užívatel' je schopný s priestorovým modelom manipulovat', priblížit si rôzne detaily a prehliadnut si artefakt zo všetkých strán bez nutnosti fyzického prístupu ku nemu. Rovnako tak je možné získat priestorové dáta o trojrozmerných modeloch a podrobit' ich d’alším analýzam.

Velkou výhodou 3D modelov je možnost presnej metrickej analýzy, rezov a pri nádobách je možnosṫ získat aj vnútorný objem. Momentálne sa experimentuje s možnostou generovania automatickej kresby z 3D modelov (napr. Wilczek a kol. doposial' nepublikované; Porter Roussel - Soressi 2016).

Limity 3D skenovania $\mathrm{v}$ archeológií zatial spočívajú hlavne v textúre. Niektoré typy 3D skenerov zachytávajú presný geometrický tvar, avšak povrchová textúra je pre nich stále pomerne tažko zaznamenatelná. Najvýraznejšie sa tento nedostatok prejavuje pri tmavých a lesklých predmetoch. Ako problém pri niektorých 3D skeneroch sa tiež javí zachytenie tvaru pri malých alebo tenkých tvaroch, pretože sa na nich svetelné vzory, či už laserové, alebo binárnej štruktúry, rozptylujú alebo sú pohlcované. ${ }^{5}$

\section{Dokumentované artefakty}

V článku je porovnanie dokumentačných metód skúmané na príklade siedmich stredovekých šachových figúrok, pričom všetky boli zapožičané zo zbierok Múzea mesta Brna. Z celkového počtu figúrok spracovaných v našej práci je šest̃ vyrobených z dreva a jedna z kosti. Drevené figúrky boli objavené behom výskumu benediktínskeho prepoštstva „Na Luhu“ v roku 1973, kedy bola bližšie preskúmaná kamenná studňa v Brne - Komárove (Kochan - Sedláčko$v a ́$ - Vachůt 2015). Studňa bola po strate svojej pôvodnej funkcie využívaná ako odpadová jama a s kombináciou zavodneného prostredia bolo možné dochovanie týchto unikátnych drevených nálezov.

Kostená figúrka objavená samostatne, pochádza rovnako ako drevené figúrky z Brna. Bola objavená pri záchrannom archeologickom výskume, ktorý predchádzal výstavbe parkovacieho domu na Panenskej ulici, ktorá ústi do hornej časti Dominikánského náměstí. Bol uskutočnený pod vedením Mgr. Petra Holuba a neskôr pod vedením Mgr. Pavla Staňka zo spoločnosti Archaia z.ú. Torzo kostenej figúrky bolo na základe miesta nálezu predbežne datované do prvej polovice 13 . storočia. ${ }^{6}$

\section{Dokumentácia materiálu a jeho degradácia}

Materiál hrá vel'mi dôležitú úlohu pri výbere tej ktorej dokumentačnej techniky, a preto je dôležité aby o ňom bolo v krátkosti pojednané. Čo sa týka dreva, to je obecne v archeologických nálezov zastúpené len vo vel'mi nízkej miere. Ak sa drevo podarí dochovat, je to dôsledok vhodnej prirodzenej konzervácie, ktorá však má na materiál výrazný vplyv a mení jeho vnútornú štruktúru (Zelinger - Šimunková - Kotlik 1982, 137). Zníženie materiálovej pevnosti a pružnosti sa prejavuje mäkším drevom, ktoré je následne pri neopatrnej manipulácií velmi jednoduché poškodit. V prípade skúmaných figúrok sa deštrukcia materiálu spôsobená nasýtením vodou, prejavila stratou pórovitosti a mäkkostou materiálu. Oproti pôvodnému suchému drevu sú figúrky pravdepodobne zmenšené, čo je zapríčinené stratou celulózy, ktorá podlieha účinkom mikroorganizmov, a to vedie práve ku zmenšeniu povrchu a k zväčšovaniu dutín v dreve (Págo 1985, 55). Aby sa predišlo praskaniu dreva a d’alšej degradácií, je nutná jeho konzervácia. V archeológií sa najčastejšie využíva metóda 


\begin{tabular}{|c|c|c|c|c|c|}
\hline Inv. č. & Materiál & $\begin{array}{c}\text { Hmotnost' } \\
\mathbf{( g )}\end{array}$ & $\begin{array}{c}\text { Výška } \\
\mathbf{( c m})\end{array}$ & $\begin{array}{c}\text { Priemer hlavičky } \\
\mathbf{( c m})\end{array}$ & $\begin{array}{c}\text { Priemer podstavy } \\
\mathbf{( c m})\end{array}$ \\
\hline 304131 & Drevo & 44 & 5,4 & 3,5 & 3,8 \\
\hline 304432 & Drevo & 17 & 5,9 & 3 & 3 \\
\hline 304133 & Drevo & 29 & 4,5 & 3,4 & 3,5 \\
\hline 304134 & Drevo & 15 & 4,8 & 2,4 & 3,2 \\
\hline 304135 & Drevo & 26 & 5,5 & 2,9 & 3 \\
\hline 304136 & Drevo & 18 & 5 & 2,8 & 2,2 \\
\hline 442309 & Kost' & 16 & 4,1 & 1,8 & 2,1 \\
\hline
\end{tabular}

Tab. 1. Tabul'ka s inventárnymi číslami, materiálom, hmotnostou a rozmermi figúrok (Kosmelová 2018, 22).

Tab. 1. Table with inventory numbers, material, weight and dimensions of chess pieces (Kosmelová 2018, 22).

bez predchádzajúcej dehydratácie, ktorá spočíva v impregnácii vodou nasýteného dreva vo vodnom roztoku polyetylénglykole, skrátene v PEG-u, ktorá bola využitá aj pri konzervácií týchto šiestich drevených figúrok.

Od vyzdvihnutia drevených figúrok ubehlo 46 rokov, pričom prvého spracovania sa dočkali v roku 2014, kedy súbor na základe analýzy autora ani po 40. rokoch nevykazoval stopy závažnej degradácie (Kochan 2014, 56). V súčasnej dobe sú však figúrky vel'mi krehké, objavujú sa na nich stopy degradácie povrchu a drevo mäkne. Figúrky sú náchylné k praskaniu a drveniu ich časti. Je potrebná extrémne opatrná manipulácia.

Kost' predstavuje jednu z najpevnejších typov biologického materiálu. Konzervácia kostených predmetov sa odvíja od stavu a tiež od charakteru ich využitia. Iné postupy sa využívajú pre konzerváciu materiálu, ktorý bude v budúcnosti podrobený antropologickým a archeologickým analýzam a iné postupy sa volia pre predmety, ktoré budú slúžit pre múzea ako reprezentačný materiál. Kostrové pozostatky pochádzajúce z archeologických výskumov sú vyzdvihované v rôznom stave zachovania. V niektorých prípadoch sa využíva metóda in situ zaliatím do sadry. Bežne sa nálezy ošetrujú len rýchlym umytím vo vode a dôkladným usušením na vzduchu. V niektorých prípadoch sa následne pristúpi k ošetreniu predmetu prostriedkami na báze organických polymérov, ktoré spevnia štruktúru kosti, sú bezfarebné a stabilné (Johnson 1994, 221). Je nutné brat’ v úvahu, že takýto charakter konzervácie je nenávratný a mohol by skreslit chemické analýzy. Pre predmety, ktoré budú využité k d’alším analýzam, sa využíva očistenie čistou vodou, alebo aplikácia len povrchového náteru (Smith 2003). Analyzovaná figúrka však žiadnu konzerváciu nepodstúpila a na základe informácie od pracovníkov Múzea města Brna, bola len umytá vodou, bez d’alších zásahov.

Bližšie informácie o inventárnom čísle, materiáli, rozmeroch a hmotnosti figúrok sú uvedené v Tab.1. ${ }^{7}$

\section{Metódy a ich analýza}

Nasledujúca kapitola obsahuje detailne popísaný postup, metódy, čas potrebný k vyhotoveniu, spracovanie a výpočtovú náročnost́. Cielom je na základe vlastnej skúseností zhodnotit finančnú a časovú náročnost’ jednotlivých postupov dokumentácie. 


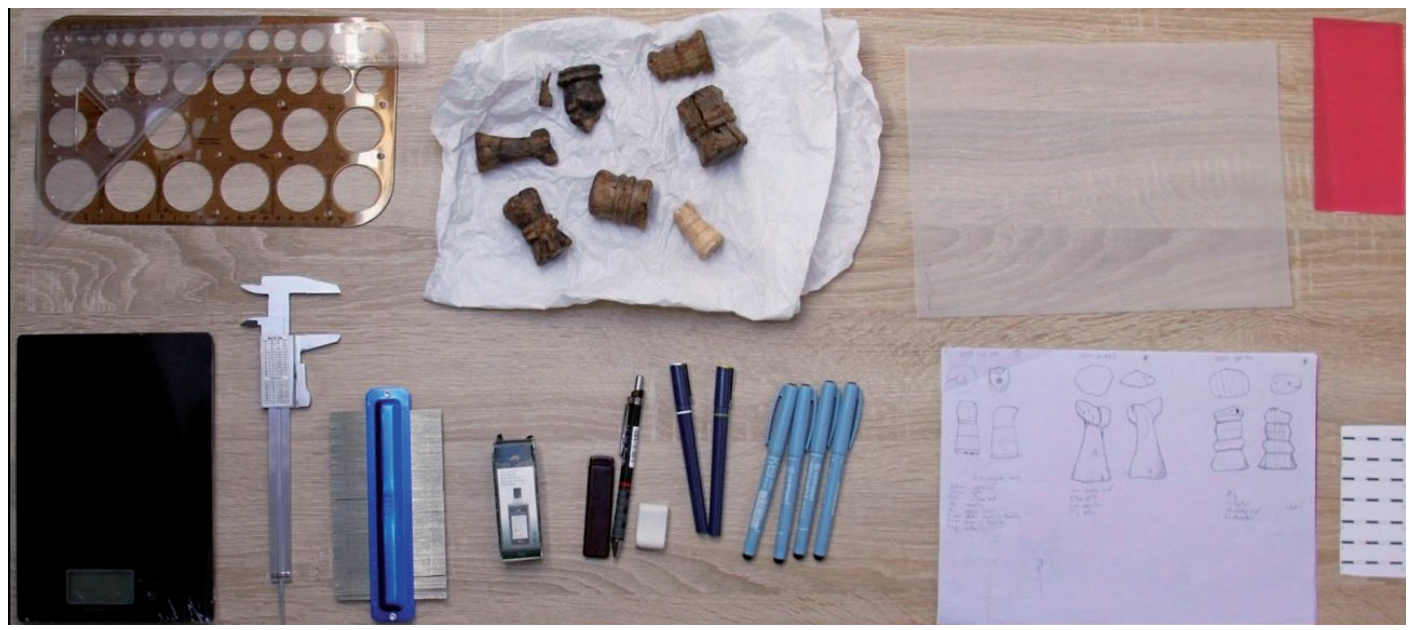

Obr. 1. Pomôcky, ktoré boli využité pri kresebnej dokumentácií. Foto: N. Kosmelová.

Fig. 1. Drawing utensils. Photo: N. Kosmelová.

\section{Kreslenie}

Táto metóda je ako jediná finančne nenáročná na výbavu. Pri kresbe boli využité základné kresliace pomôcky ako: bežný kancelársky papier, pauzovací papier, mikroceruzku $\mathrm{s}$ tuhou $0,5 \mathrm{~mm}$, stredne tvrdú bielu gumu, 2 technické perá značky Faber-Castell a 4 dokumentačné fixky (svetlostále) značky Centropen s hrúbkou $0,1 \mathrm{~mm}, 0,3 \mathrm{~mm}, 0,5 \mathrm{~mm}$ a 0,7 mm. K presnej technickej kresbe boli dalej potrebné: šubléra, pravítka, profilovací hrebeň a dentálny vosk.

Pri vyhotovení kresieb sa postupovalo podla schémy navrhnutej po konzultácií s Mgr. Soňou Plchovou. ${ }^{8}$ Každá figúrka bola najskôr načrtnutá a detailne zmeraná. Následne boli na papier prenesené pomocné čiary pre dodržanie presných rozmerov figúrok. Na zakreslenie profilov bol použitý profilovací hrebeň a dentálny vosk. Výsledné kresby boli prekreslené dokumentačnými perami na pauzovací papier a následne aj zdigitalizované. Pri skenovaní bola ku predmetom priložená mierka. Dôležité bolo manuálne nastavit parametre skenovania v ovládači a v rozšírených nastaveniach. Skenovala sa v čiernobielom režime, aby sme predišli šumu a sivým odtieňom. Dosiahnutie čo najostrejších kresieb bolo docielené výstupným rozlíšením 600 DPI a nastavením výstupnej velkosti na 100\%. Kvôli finálnej úprave v grafickom editori a lepšej manipulácií boli naskenované súbory uložené vo formáte TIF. Ako graficky editor bol zvolený Adobe Photoshop CS6 (spoločnost' Adobe Systems), kde boli zarovnané figúrky podla pomocných čiar a vymazané drobné nečistoty vzniknuté pri skenovaní. Editácia pozostávala tiež z logického usporiadania figúrok, upravenia mierky a pridania popisných čísel.

Náročnost’ na spracovanie je samozrejme individuálna. Autorke štúdie, ako relatívne neskúsenej dokumentátorke, trval celý proces kreslenia (náčrt, pomeranie všetkých rozmerov, kresba na papier, prekreslenie kresby na pauzovací papier) 7 figúrok aj s konzultáciami približne 15 hodín. Editácia v grafickom editore zabrala približne d’alšie 3 hodiny. 

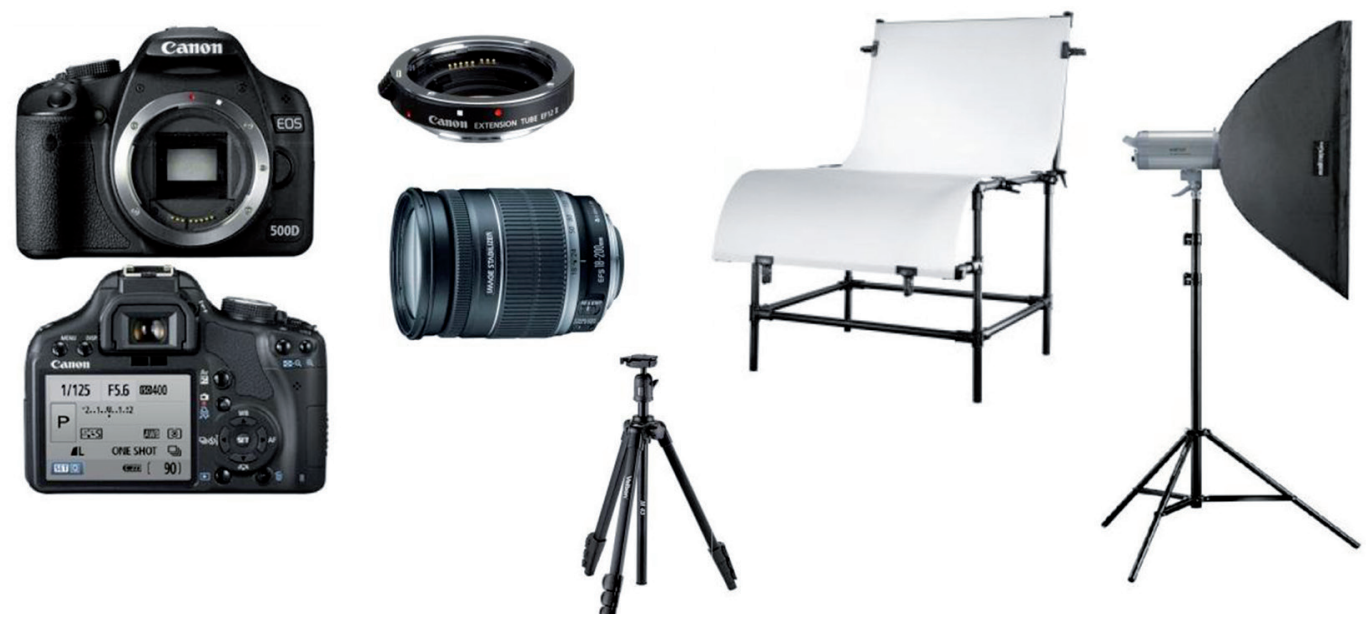

Obr. 2. Potrebné vybavenie využité na fotodokumentáciu. Digitálna zrkadlovka značky Canon Eos 500D, makrokrúžok Canon Extension Tube EF 12 II, objektív Canon EF-S 18-200 mm f/3.5-5.6 IS, fotostolík, statív a svetla (Kosmelová 2018, 43).

Fig. 2. Photographic documentation equipment used. Digital camera Canon Eos 500D, macro ring Canon Extension Tube EF 12 II, lens Canon EF-S 18-200 mm f/3.5-5.6 IS, photo table, tripod and studio lights (Kosmelová 2018, 43).

\section{Fotodokumentácia}

Pri fotodokumentácií sa obyčajne objavuje predstava, že takýto spôsob dokumentovania spočíva v namierení objektívu na snímaný predmet a v stlačení spúšte. Pre získanie kvalitne vyhotoveného záznamu je však potrebné mat̉ hned' na začiatku ujasnený koncept a účel fotografie. Na tomto základe si dokumentátor pripraví potrebné vybavenie, zvolí prostredie a nachystá fotený objekt. V našom prípade sa jednalo o vyhotovenie fotografií šachových figúrok, ktoré mali byt použité na porovnanie so staršími fotografiami a rovnako tak mali slúžit pre demonštráciu a následný popis dokumentácie.

Všetky fotografie figúrok boli vyhotovené digitálnou zrkadlovkou, značky Canon EOS 500D v 3D ateliéri na ÚAM. Vzhl'adom k vel'kosti figúrok, kedy najmenšia merala približne 4 $\mathrm{cm}$ a najväčšia figúrka okolo $6 \mathrm{~cm}$, bol použitý objektív Canon EF-S 18-200 mm f/3.5-5.6 IS, ktorý má 11x rozsiahly zoom. Pri fotografovaní bolo použité vybavenie, ktoré sa nachádza v ateliéri; plastová podložku pre fotografovanie, tzv. fotostolík s hladkým pozadím a bez hrany, statív a podložka na ktorú boli figúrky kvôli lahšej manipulácií umiestnené. Eliminácia tieňov bola dosiahnutá niekolkými svetelnými zdrojmi. Figúrky boli fotografované na neutrálnom bielom pozadí. Bolo vyhotovených viac pohladov a objekty boli fotografované s mierkou.

Pre sedem figúrok bolo vyhotovených celkom 71 snímok. Na prvých 26 snímok bol použitý makro krúžok Canon Extension Tube EF 12 II, pomocou ktorého bolo dosiahnuté relatívne vysokého stupňa špecifických detailov figúrok. ${ }^{9}$ Aj napriek použitiu dvoch svetelných zdrojov, miera ostrosti nebola zvýšená, čo sa prejavilo ostrým popredím a postupným rozostrením vzdialenejších časti snímaného objektu. Snaha o nárast miery ostrosti bola docielená fotografovaním zo statívu, ktorý bol pevne dotiahnutý a tiež s využitím o pár sekúnd oneskorenej spúšte kvôli eliminácií otrasov. Na fotoaparáte bola 


\begin{tabular}{|l|l|}
\hline Typ fotoaparátu & Digitálna jednooká zrkadlovka (DSLR) \\
\hline Rozmery & $128,8 \times 97,5 \times 61,9 \mathrm{~mm}$ \\
\hline Typ senzoru & CMOS APS-C 22,3 × 14,9 mm \\
\hline Maximálne rozlíšenie & 15,1 efektívnych Mpx, $4752 \times 3168$ \\
\hline Citlivost' & ISO 100 až 12800 \\
\hline Výstupný formát & RAW, JPEG \\
\hline Celkový počet megapixelov & 15.5 Mpx \\
\hline Čas uzávierky & Min. $1 / 4000 \mathrm{~s}-\max .30 \mathrm{~s}$ \\
\hline
\end{tabular}

Tab. 2. Technické parametre digitálnej zrkadlovky (Kosmelová 2018, 44).

Tab. 2. Technical parameters of the digital reflex camera used (Kosmelová 2018, 44).

\begin{tabular}{|l|l|}
\hline Vel'kost' obrázku & APS-C \\
\hline 35 mm film ekvivalentnej ohniskovej vzdialenosti & $29-320$ \\
\hline Zorný uhol (horzntl., vertl., diagnl.) & $64^{\circ} 30^{\prime}-6^{\circ} 30^{\prime}, 45^{\circ} 30^{\prime}-4^{\circ} 20^{\prime}, 74^{\circ} 20^{\prime}-7^{\circ} 50^{\prime}$ \\
\hline Konštrukcia objektívu (prvky/skupiny) & 16. XII \\
\hline Počet čepiel'ok membrány & 6 \\
\hline Minimálna clona & $22-38$ (36) \\
\hline Minimálna zaostrovacia vzdialenost' (m) & 0.45 \\
\hline Maximálne približenie (x) & 0,24 (pri 200 mm) \\
\hline Stabilizátor obrazu & $4-k r o k o v y ́$ \\
\hline Aktivátor AF & Mikro Motor \\
\hline Max. priemer x dížka (mm) & $78,6 \times 102$ \\
\hline Hmotnost' (g) & 595 \\
\hline Priblíženie - medzikrúžok EF12 II & $0,39-0,06$ \\
\hline Clona objektívu & EW-78D \\
\hline
\end{tabular}

Tab. 3. Zobrazenie technických parametrov objektívu (Kosmelová 2018, 44-45).

Tab. 3. Technical parameters of the lens used (Kosmelová 2018, 44-45).

vypnutá stabilizácia obrazu, ktorá sa používa hlavne pri fotografovaní z ruky, no pri fotografovaní zo statívu a s dlhším časom má opačný efekt. Ďalej sa ostrost̉ objektu dá docielit nastavením dlhšieho času a pri pokročilejších digitálnych zrkadlovkách aj predsklopením zrkadla.

Ďalším problémom, ktorý vznikol pri fotografovaní, bolo objavenie chromatickej aberácie, ktorá je pravdepodobne zapríčinená nedostačujúcimi povrchovými úpravami skiel v objektíve. Moderné zoomové objektívy obsa- hujú vel'ké množstvo šošoviek a vd’aka tomu je chromatická chyba obzvlášt na kraji snímky výrazným problémom, pretože šošovky lámu svetlo každej farby odlišne. Táto chyba sa prejavuje farebným lemovaním kontrastných hrán (Král 2010, 85). Problém bol však jednoducho odstránený pomocou softvéru Adobe Photoshop Lightroom (spoločnost’ Adobe Systems) v sekcii Chromatic Aberration, kde boli menené hodnoty u jednotlivých farieb pokial' nebolo dosiahnuté čo najvyššie potlačenie aberácie. 


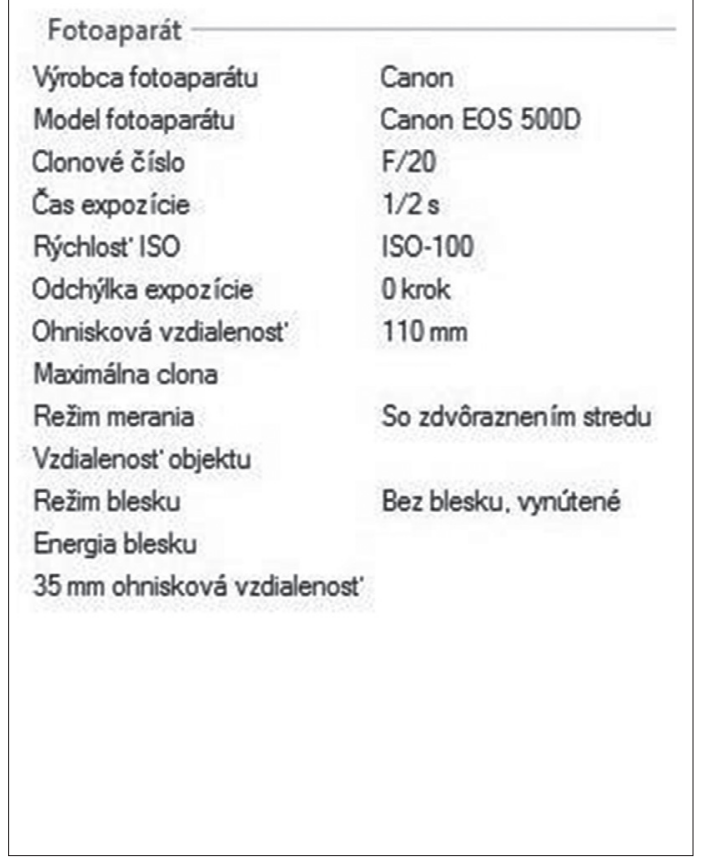

Obr. 3. Nastavenie hodnôt fotoaparátu (Kosmelová 2018, 46).

Fig. 3. Camera settings (Kosmelová 2018, 46).

Nasledujúcich 45 snímok bolo zhotovených (vid’ obrázok 4) bez makrokrúžku s nastavením nasledujúcich hodnôt (vid’ obrázok 3).

Fotografie boli pracovne roztriedené do dvoch kategórií; na doplnkové a hlavné. Do prvej spadali fotografie, ktoré boli vyhotovené s pomocou makro krúžku. Tieto fotografie poskytujú zaujímavé informácie a detaily objektov, nevyjadrujú však ich podstatné črty. Hlavné snímky naopak predstavujú celkovú charakteristiku artefaktu z hladiska požadovaného účelu.

Následný postprocessing bol vykonaný v dvoch grafických programoch; Adobe Photoshop CS6 a Adobe Photoshop Lightroom, kedy boli fotografie $\mathrm{v}$ konečnom dôsledku rozmiestnené na A4, upravené a popísané. ${ }^{10}$ Proces vyhotovenia všetkých fotografií $\mathrm{v}$ ateliéri

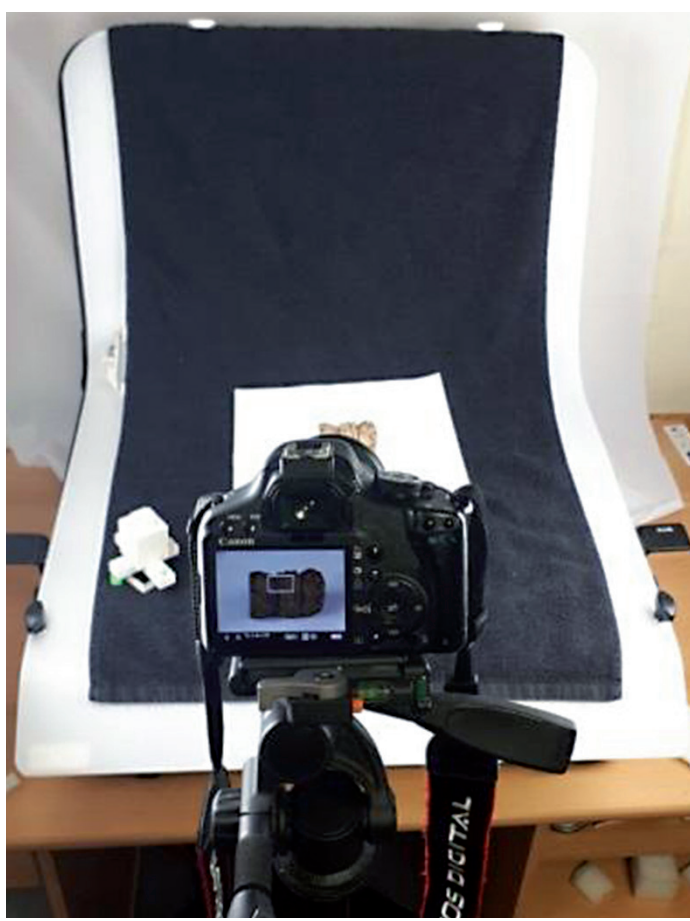

Obr. 4. Proces vzniku fotografií v 3D ateliéri. Foto: N. Kosmelová.

Fig. 4. Photo acquisition process. Photo: N. Kosmelová.

trval hodinu. Následná editácia (zjednotenie mierky a pozadia, pripojenie identifikačných čísel a tvorba výslednej A4) zabrala hodinu práce, vo výsledku tak práca celej fotodokumentácie zabrala 2 hodiny.

\section{D Fotogrametria}

Vybavenie, ktoré je potrebné k vyhotoveniu trojrozmerného modelu pomocou 3D fotogrametrie je totožné s vybavením potrebným $\mathrm{k}$ fotodokumentácií. Na nafotenie dokumentovaných artefaktov bolo opät využité vybavenie 3D ateliéru ÚAM, fotoaparát značky Canon EOS 500D a notebook Lenovo IdeaPad B580.

Postup bol nasledovný; ako prvé bolo potrebné získat fotografie, ktoré boli snímané zo 


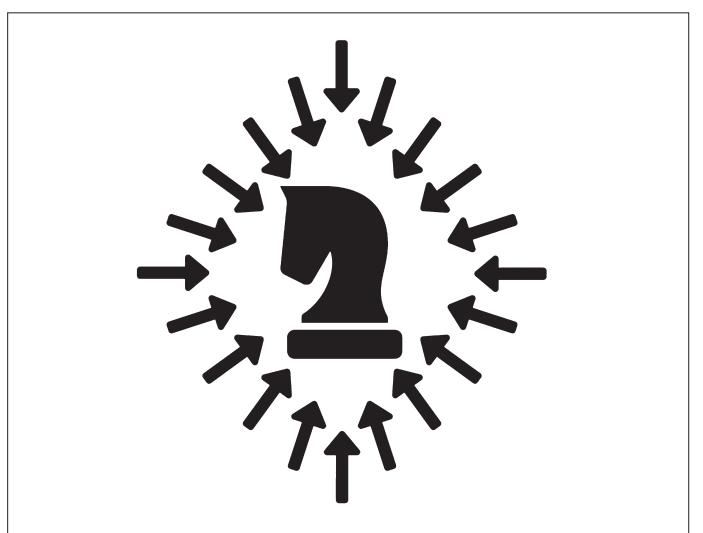

Obr. 5. Zvolený princíp rozvrhnutia jednotlivých pozícií okolo dokumentovaných figúrok (Kosmelová 2018, 48).

Fig. 5. Arrangement of individual stands around the documented chess pieces. (Kosmelová 2018, 48).

statívu s využitím časovača kvôli zamedzeniu drobným otrasom. Kvôli l’ahšej manipulácií bolo zvolené umiestnenie artefaktov na rotujúcu podložku. Pre vytvorenie trojrozmerných modelov šachových figúrok bola zvolená metóda konvergentného snímkovania, ktoré spadá do viacsnímkovej fotogrametrickej metódy, založenej na princípe čo najväčšieho prekryvu fotografií. Ideálne prekrytie fotografií je $60 \%$ a viac (Plzák 2016, 101). Pre docielenie čo najpresnejšieho modelu bolo vyhotovených 60 snímok; 20 snímok z čelného pohladu, 20 snímok spodnej časti a 20 snímok hlavičky figúrky, t.j. figúrky boli rotované na podložke po $18^{\circ}$ (vid' obrázok 5). Ak bolo potrebné pri vyhotovovaní fotografií spodnej a vrchnej časti, niektoré figúrky boli kvôli stabilizácií uložené do polystyrénovej formy.

Aby bola zaistená čo najvyššia kvalita výsledných modelov, vzdialenost fotoaparátu od figúrky sa menila len v rade milimetrov. Clona, čas expozície a ISO ostávali vždy rovnaké. Nastavenie clony bolo 16 , čas expozície $1 / 6 \mathrm{~s}$. a ISO malo hodnotu 100. Niektoré softvéry vyžadujú pevnú ohniskovú vzdialenost', na čo treba brat’ ohlad.

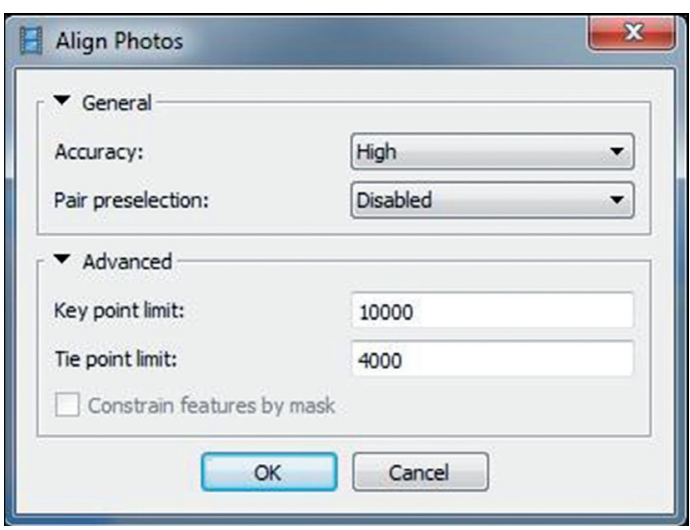

Obr. 6. Nastavenie, ktoré bolo použité k zarovnaniu (Kosmelová 2018, 49).

Fig. 6. Settings used for alignment (Kosmelová 2018, 49).

Ako výpočtový softvér bol využitý program Agisoft PhotoScan (spoločnosti Agisoft), ktorý model počíta priamo na počítači samotného užívatela (parametre notebooku vid' tabul'ka č. 4).

Pred využitím programu Agisoft Photoscan, ale aj iných softvérov je dobré si fotoaparát s objektívom skalibrovat. V prípade Agisoftu bola kalibrácia vykonaná pomocou Agisoft Lens. Pri tomto procese je nafotená čierno biela šachovnica na monitore $\mathrm{z}$ viacerých smerov a po spracovaní programom získame kalibračné hodnoty objektívu, ktoré následne využívame v projekte Photoscanu.

Prvým krokom pri samotnom modelovaní je nahranie fotografií do programu a ich vymaskovanie. Velkkou výhodou pri popisovanom programe je to, že nový nástroj, ktorý ul'ahčuje vymaskovanie dokáže previest' odmaskovanie z jednej fotografie a následne podla nej odmaskuje všetky ostatné snímky.

Druhým krokom je zarovnanie a vypočítanie vonkajšej a vnútornej orientácie snímky, ktoré docielime funkciou Align (vid' obrázok 6). Špeciálny algoritmus, ktorý funguje na báze triangulácie nájde na jednotlivých fotografiách spoločné body a pomocou nich dokáže spočítat 


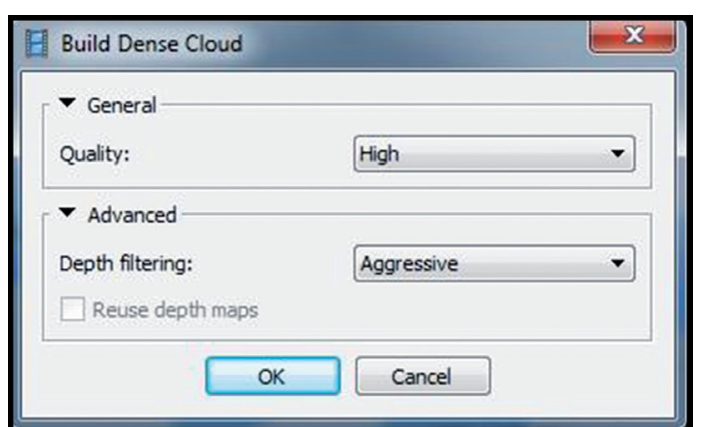

Obr. 7. Nastavenie použité pri výpočte mračna bodov, tzv. Dense cloud (Kosmelová 2018, 49).

Fig. 7. Settings used for dense cloud reconstruction (Kosmelová 2018, 49).

\begin{tabular}{|c|c|}
\hline Build Mesh & 5 \\
\hline \multirow{4}{*}{$\begin{array}{l}\text { General } \\
\text { Surface type: } \\
\text { Source data: } \\
\text { Face count: }\end{array}$} & \\
\hline & Arbitrary \\
\hline & Dense cloud \\
\hline & High $(347,796)$ \\
\hline \multirow{3}{*}{$\begin{array}{l}\text { Advanced } \\
\text { Interpolation: } \\
\text { Point classes: All }\end{array}$} & \\
\hline & Enabled (default) \\
\hline & Select... \\
\hline OK & Cancel \\
\hline
\end{tabular}

Obr. 8. Nastavenie použité pri výpočte polygonovej siete, tzv. Mesh (Kosmelová 2018, 49).

Fig. 8. Settings used for mesh reconstruction (Kosmelová 2018, 49).

pozíciu jednotlivých pohl'adov na dokumentované figúrky. Ak ide o ručné určenie bodov, je vhodné dávat' okolo dokumentovaného objektu dobre viditel'né značky.

$\mathrm{Na}$ základe triangulácie je vypočítaný tzv. Dense cloud (vid' obrázok 7), alebo mračno bodov, kedy má každý bod v priestore svoje $\mathrm{x}, \mathrm{y}$ a z súradnice. Následne je z mračna bodov vypočítaná polygonálna siet’ (vid' obrázok 8), kde sme zvolili nastavenie arbitrary, ktorá vypočíta lubovolné mračno bodov.

Posledným krokom je výpočet textúry modelu. Ide o najvrchnejšiu vrstvu pokrývajúcu celý

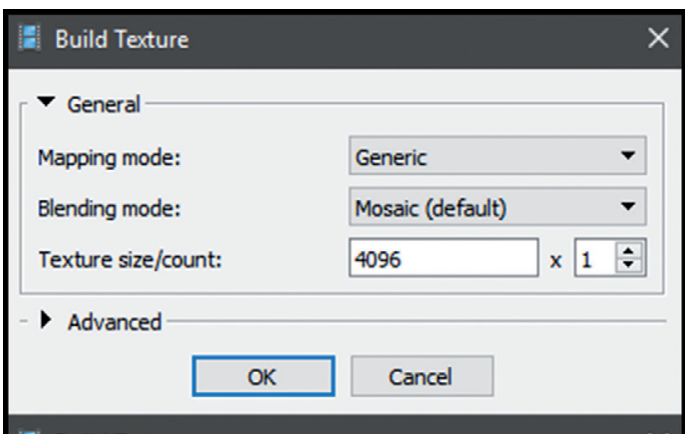

Bif Build Texture

\section{$\checkmark$ General}

Mapping mode:

Blending mode:

Texture size/count:

Advanced

\section{Generic}

Generic

Adaptive or thophoto

Spherical

Single camera

Keep uv

OK

Cancel

Obr. 9. Znázornenie nastavenia použitého pre výpočet textúry a jej možnosti (Kosmelová 2018, 50).

Fig. 9. Settings used for calculation of texture and its other possibilities (Kosmelová 2018, 50).

povrch digitálnej kópie artefaktu. Textúra predstavuje jednu z najdôležitejších aspektov, ktoré nám trojrozmerný model môže priniest'. Je tvorená na základe fotografií, ktoré sú aplikované na model pomocou definovaných bodov (Nosek 2014, 157). V tomto kroku je tiež možné počítat ortofoto plán, pohlad z osy z a pod. (vid' obrázok 9).

Výsledné modely sa dajú exportovat do rôznych formátov, pričom pre potreby práce sme zvolili formáty .obj a .ply, kvôli ich širšiemu využitiu a podpore v rôznych programoch, ktoré sme následne využívali k editácií alebo domodelovaniu.

Problémom, ktorý sa objavil pri vytváraní niektorých trojrozmerných modelov spočíval v tom, že niekedy sa objavil okolo modelov biely prstenec, ktorý bolo možné odstránit pomocou nástroja Blending mod, ktorý v prostredí digitálneho editovania grafiky predstavuje spôsob, 


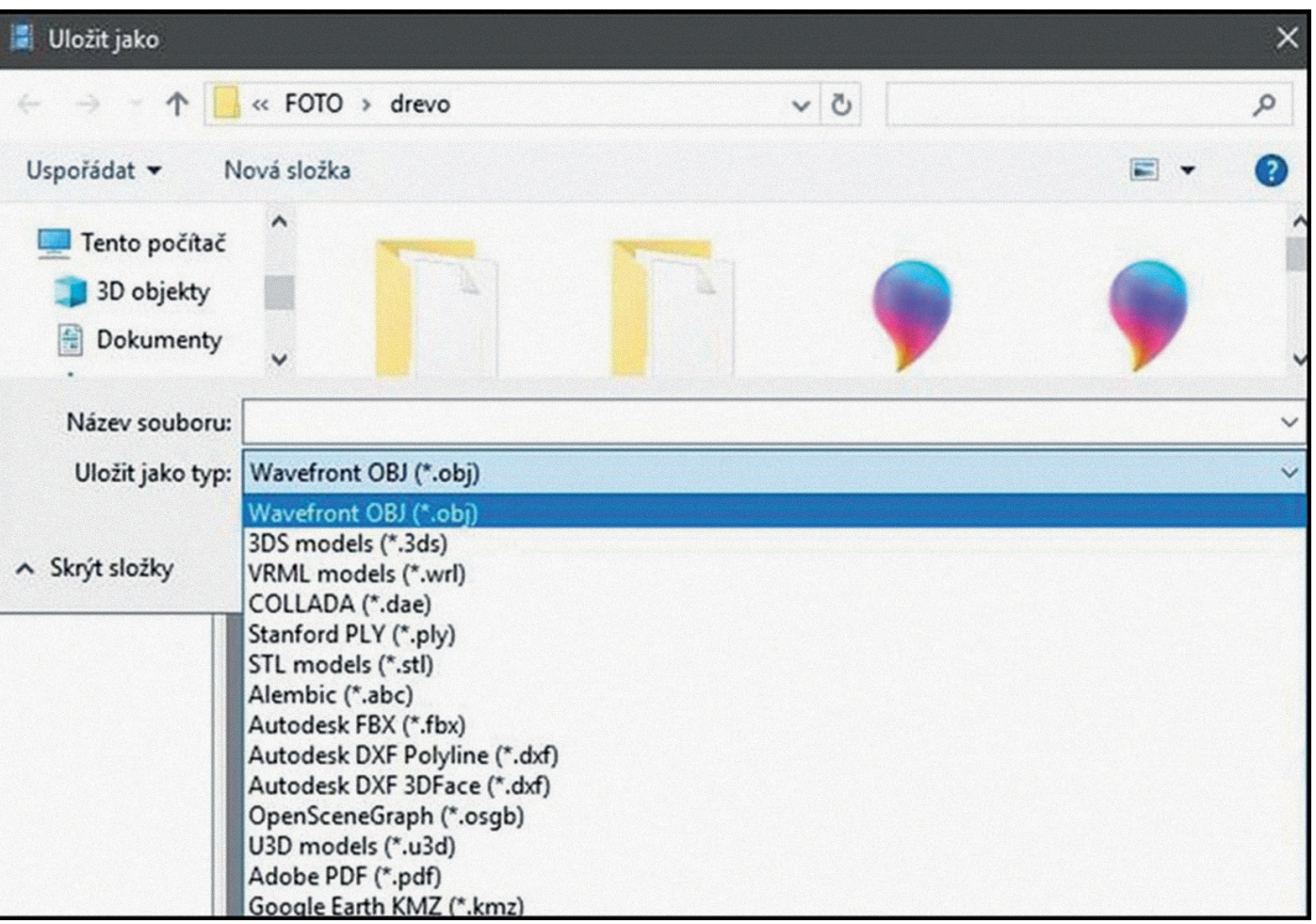

Obr. 10. Ukážka rôznych formátov, v ktorých je možné model uložit' (Kosmelová 2018, 50).

Fig. 10. Various formats, in which the model can be saved (Kosmelová 2018, 50).

akým sú dve vrstvy zmiešané. Pri jeho nastavení na minimálnu intenzitu vznikla ostrejšia textúra a biely prstenec bol eliminovaný. Ked’že tento problém sa zistil hlavne pri figúrkach, ktoré mali menšiu stabilitu a pre ich nafotenie musela byt použitá polystyrénová podložka, pre zmiernenie spomínaného prstenca sa nafotila nová séria fotiek, kedy boli figúrky na podložku umiestnené vodorovne.

Proces nafotenia všetkých fotografií pre modeláciu trojrozmerného modelu zabral celkovo 3 hodiny čistého času. Samotné modelovanie vo vel'mi vel'kej miere závisí na výpočtovej sile použivaného hardvéru. Pre porovnanie uvádzam čas, za ktorý bol model vypočítaný na notebooku Lenovo IdeaPad B580 v kontraste s časom, ked' bol počítaný na notebooku HP Elite Book 8770w (vid' parametre v tabul'ke č. 4.), ktorý bol zvolený pre svoje vhodnejšie technické špecifi- kácie. Celkový čas výpočtu figúrok od nahrania fotografie po vytvorenie textúry predstavoval v prípade notebooku, značky Lenovo IdeaPad B580 5 hodín, pričom na notebooku HP Elite Book 8770 w len 40 minút. Časy sú uvádzané pre výpočet modelu jednej figúrky, ktorá si vyžiadala priemerný počet snímok. Časy sa samozrejme môžu lísit v závislosti na nutnosti zapojenia viacej či menej fotografií do procesu - tak, aby ich hustota pokrývala viac či menej komplexný tvar dokumentovaného artefaktu.

\section{D Skenovanie}

V rámci testovania a porovnávania rôznych dokumentačných metód bolo vyskúšaných aj niekol'ko 3D skenerov. Jedným z nich bol aj laserový 3D skener NextEngine, ktorý bol zvolený pre 


\begin{tabular}{|l|l|l|l|}
\hline Notebook & HP EliteBook 8770w & Lenovo IdeaPad B580 & Lenovo IdeaPad Z560 \\
\hline Procesor & $2,7 \mathrm{GHz}$ & $2,2 \mathrm{GHz}$ & $2,4 \mathrm{GHz}$ \\
\hline RAM & $16 \mathrm{~GB}$ & $4 \mathrm{~GB}$ & $4 \mathrm{~GB}$ \\
\hline Grafická karta & AMD Radeon HD 7700M 1024 MB & Intel HD Graphics 3000 & Nvidia GeForce 310M \\
\hline
\end{tabular}

Tab. 4. Porovnanie parametrov jednotlivých notebookov, použitých pri výpočte (Kosmelová 2018, 51).

Tab. 4. Comparison of parameters of individual notebooks used for calculations (Kosmelová 2018, 51).
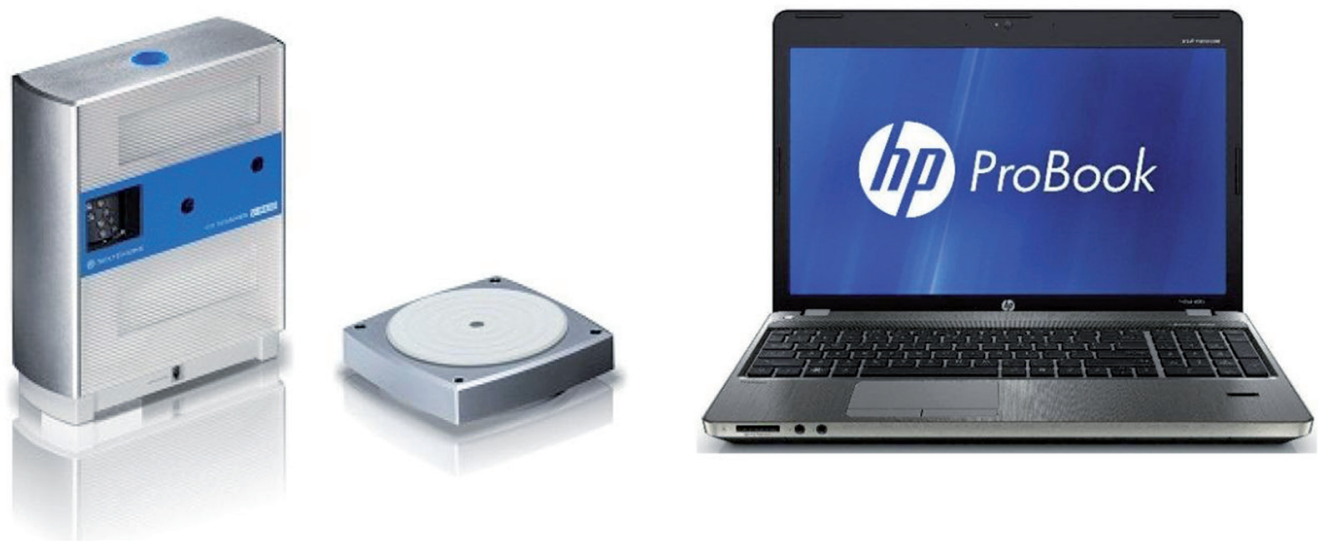

Obr. 11. Pre účely 3D skenovania bol použitý 3D skener NextEngine s rotačnou podložkou a HP ProBook 4740s (Kosmelová 2018, 52).

Fig. 11. For 3D scanning was used 3D scanner NextEngine with rotary table and HP ProBook 4740s (Kosmelová 2018, 52).

vyhotovenie 3D modelov vd’aka svojmu intuitívnemu a jednoduchému ovládaniu, doplnenému relatívnou kvalitou záznamu a dostupnostou. Medzi jeho hlavné výhody patrí zaznamenávanie povrchových farebných vlastností objektov, ktoré bolo jedným z hlavných kritérií výberu.

Súčastou prístroja je otočný stolček, ktorý podla potreby 3D skenovania sám objekt rotuje. Samotný 3D skener má v sebe zabudovanú kameru, ktorá zaznamenáva pohyb laserového lúča po povrchu daného objektu. 3D Skener je ovládaný pomocou jednoduchého programu NextEngine ScanStudio, ktorý po otvorení v notebooku automaticky aktivuje 3D skener.

Program je po užívatel'skej stránke velmi príjemný. Po zadaní príkazu skenovat sa objaví tabul'ka s nastaveniami a s náhladom na daný objekt, ktorý sa mení podla nastavenia v tabulke (vid' obrázok 12). Aby bol obraz čo najostrejší 3D skenovaný predmet je žiaduce umiestnit na stred a skontrolovat jeho vzdialenost’ od 3D skenera.

V prvej kolónke Positioning je nastavenie systému snímania. Na výber je snímanie $360^{\circ}$, ktoré sníma objekt po celom jeho obvode. Túto možnost̉ sme používali najčastejšie. Pri 3D skenovaní niektorých figúrok sa stalo, že strany boli občas zle zachytené, alebo program prestal pracovat. V týchto prípadoch bola vybraná druhá možnosté, kedy bol doskenovaný len určitý pohlad. Posledná možnost’ predstavuje naskenovanie jednotlivého pohladu, ktorú 


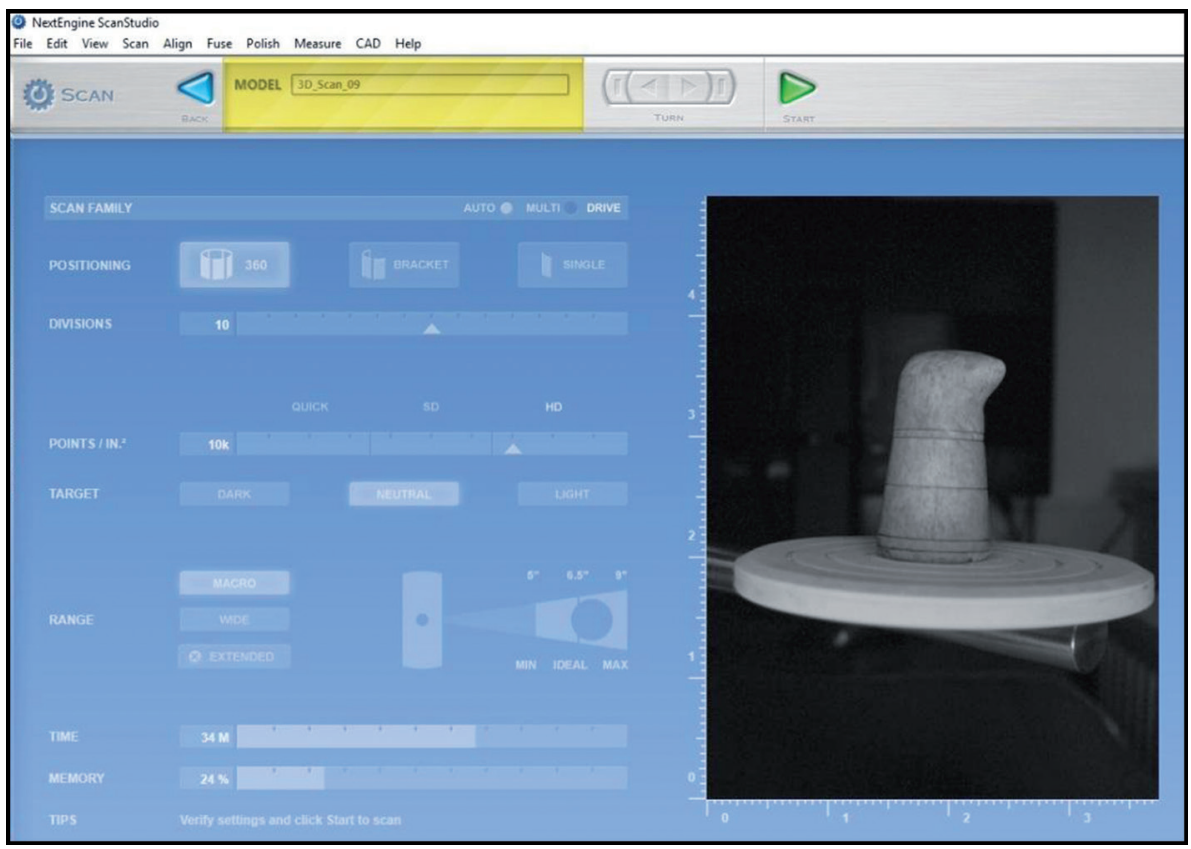

Obr. 12. Užívatel'ské rozhranie programu NextEngine so vstupnými možnostáami 3D skenovania (Kosmelová 2018, 53). Fig. 12. User interface of the NextEngine software with used values (Kosmelová 2018, 53).

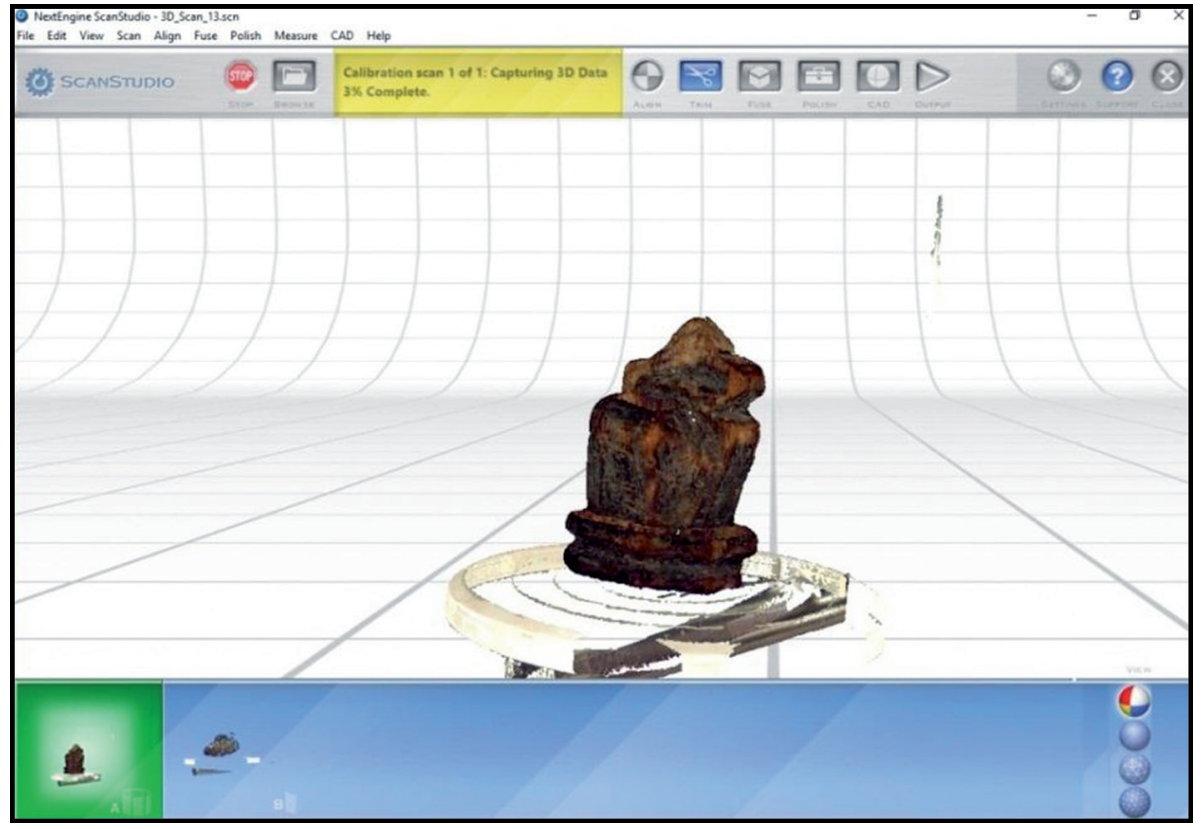

Obr. 13. Proces skenovania. Figúrka zobrazená pred čistením od pozadia a drobných nečistôt (Kosmelová 2018, 54).

Fig. 13. Scanning process. 3D model is viewed with undesirable surrounding noise (Kosmelová 2018, 54). 
sme ale nevyužívali. Divisions nám udáva kol'ko skenov má byt’ vyhotovených. Všeobecne platí, čím viac, tým je model viac detailnejší, no opät s vyšším počtom rastie aj náročnost̉ celého procesu. Points predstavuje počet použitých bodov na palec. Ideálne by bolo, ak by ich bolo 40 000, ale medzi nastavením Standard a Hard je dost' skok čo sa týka náročnosti na počítač. Po testovaní rôzneho nastavenia boli všetky figúrky naskenované v režime najslabšieho HD, ktorý bol úplne dostačujúci.

Target bol pri prvom 3D skenovaní nastavený na Dark, kvôli povrchu figúrok, no 3D skenovanie muselo byt pozastavené kvôli príliš tmavej textúre a režim bol zmenený na Neutral.

Range je nastavenie vel'kosti 3D skenovaného objektu. Pre naše účely bolo použité nastavenie makro, kedy boli objekty najviac ostré.

Vedla trojrozmerného skenovania povrchu pomocou niekolkých laserových lúčov zaznamenáva zabudovaná kamera aj povrchové informácie. Informácie sú zaznamenané pomocou farebnej fotografie, z ktorej je po dokončení 3D skenovania vytvorená textúra objektov. Po vyhotovení fotografií začína samotný 3D sken. Kamery zabudované v 3D skeneri zaznamenávajú deformáciu povrchu, ktorá je vo výsledku spojená do trojrozmernej súradnicovej siete. Pri zaznamenávaní figúrok boli vyhotovené vždy dva skeny; jeden kedy bola os figúrky horizontálne a druhý, kedy bola os figúrky vertikálne. Oba pohlady trvalo naskenovat’ približne 40 minút.

$\mathrm{V}$ momente, kedy boli doskenované oba pohlady, bolo treba pripravit figúrky k zlúčeniu. Táto príprava pozostáva z orezania podložky a možných nečistôt, ktoré pri 3D skenovaní vznikli. Použitý bol jednoduchý a rýchly polygonálny nástroj a jeho pomocou boli odstránené všetky nečistoty okolo modelu a podložka, na ktorej boli figúrky skenované. Prípadne na drobné a malé nečistoty bol používaný nástroj kolečko, ktorý funguje podobne ako guma v kreslení. Program NextEngine ScanStudio (spoločnosti NextEngine) bohužial' neumožňuje odmaskovanie jedného objektu, ktorý by bol následne aplikovaný na ostatné.

Po orezaní, začistení a pripravení skenov na d’alšiu manipuláciu nasledoval proces spojenia dvoch vyhotovených skenov. V základnej verzií programu nedokážu byt 3D skeny, ktoré nie sú v jednej polohe, voči sebe zarovnané. Pre tento úkon bola využívaná funkcia Three point alighment, kde sa prenášajú 3 farebné markery do konkrétnych miest, ktoré si na dvoch 3D skenoch odpovedajú a program si na základe určenia týchto miest sám presne vie dopočítat výsledný tvar. Zarovnávanie voči sebe trvá relatívne krátku dobu, ktorá predstavovala približne pät minút. Program s každým z 3D skenov pohybuje a snaží sa ich čo najviac priblížit, aby boli čo najpresnejšie. Po spojení dvoch skenov vznikol požadovaný trojrozmerný model.

Na doplnenie dier v modeloch bola použitá funkcia Fuse, pomocou ktorej boli postupne doplnené vzniknuté medzery. Proces funguje na princípe umelého doplnenia vytvorenej blanky do miesta, ktoré bolo zle naskenované. Hlavne kvôli tlači je dobré, aby vznikla ucelená siet. Do nastavenia je nutné zadat požadovanú toleranciu odchylky pre decimáciu. Takéto zjednodušenie modelu zmenší jeho vel'kost'. Napríklad 2000600 bodov v našom prípade bolo zredukovaných na 1000300 bodov. Program vykoná inteligentnú simplifikáciu, ktorá pridá viac bodov v detailnejších oblastiach a uberie body vo väčších rovinách. Hlboké medzery však funkcia nevyplnila, skôr ich bolo potrebné prepojit s iným, detailnejším 3D skenom. Všeobecne boli pri všetkých modeloch ale diery pekne doplnené, zakryté a výsledný model bol jednotný.

Výsledné modely je možné uložit v rôznych formátoch, my sme ich exportovali vo formáte .obj, kvôli zjednoteniu všetkých modelov. Všetky modely boli ukladané do samostatného priečinka, kde bolo uložených okolo 40 súborov. Vždy sa v priečinku nachádzal jeden hlavný 


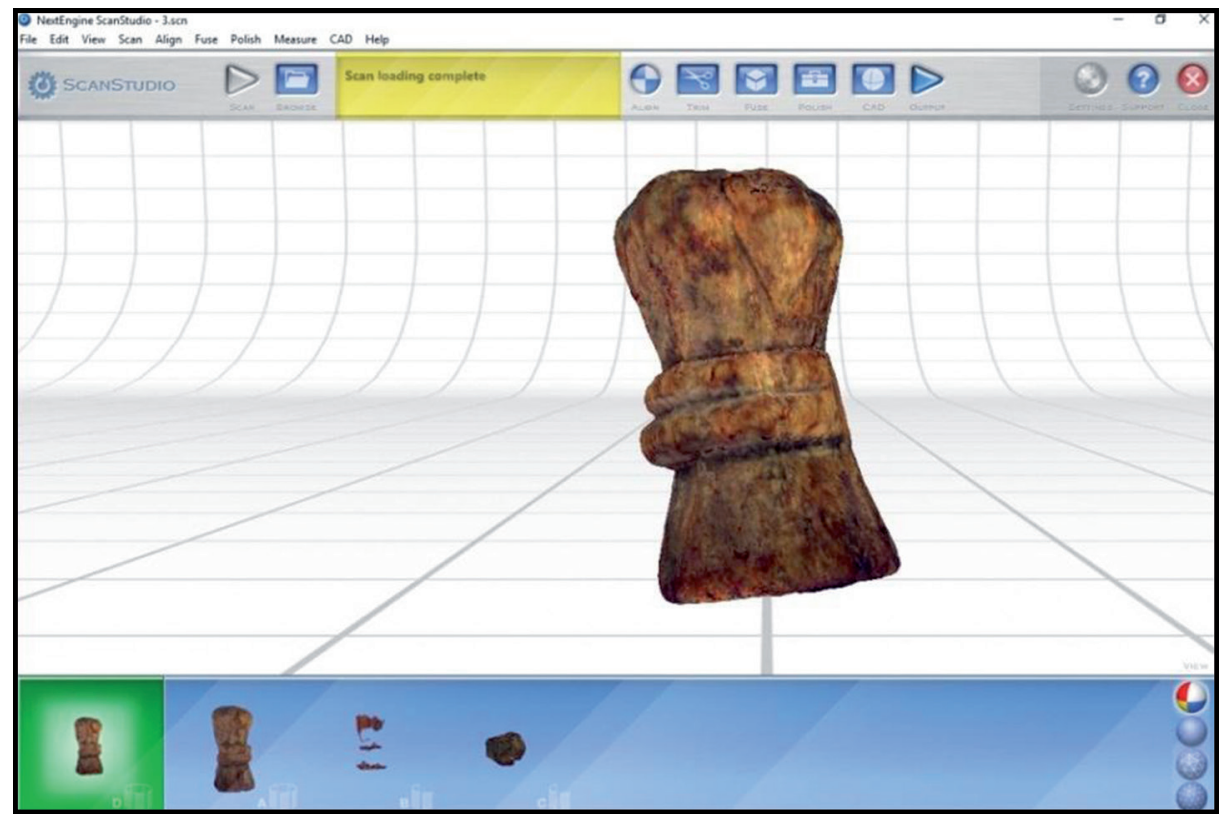

Obr. 14. Model po spojení všetkých naskenovaných častí A, B a C (Kosmelová 2018, 55).

Fig. 14. The final model created by merging all partial scans A, B and C (Kosmelová 2018, 55).

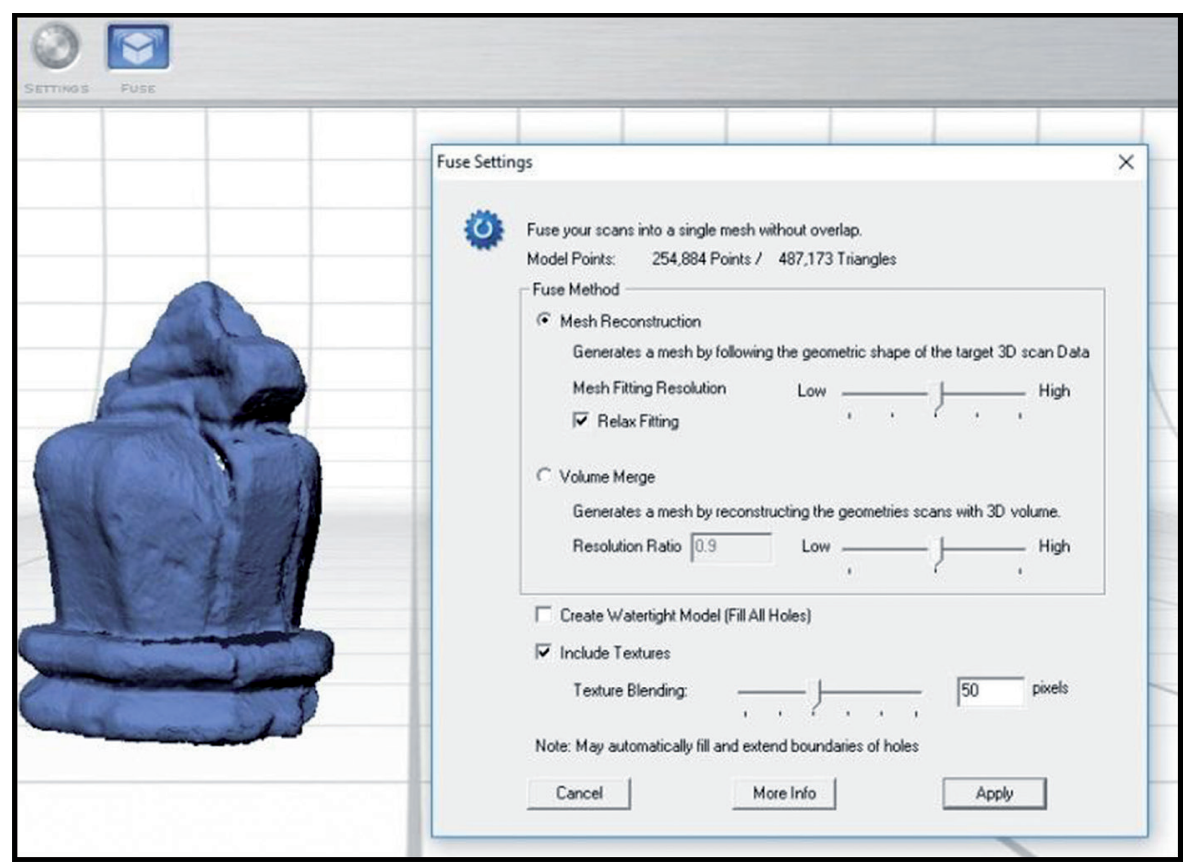

Obr. 15. Znázornenie dier v modeli a použitého nastavenia pri funkcií Fuse, na ich dopočítanie (Kosmelová 2018, 56).

Fig. 15. Holes and the Fuse algorithm settings used to fill them (Kosmelová 2018, 56). 


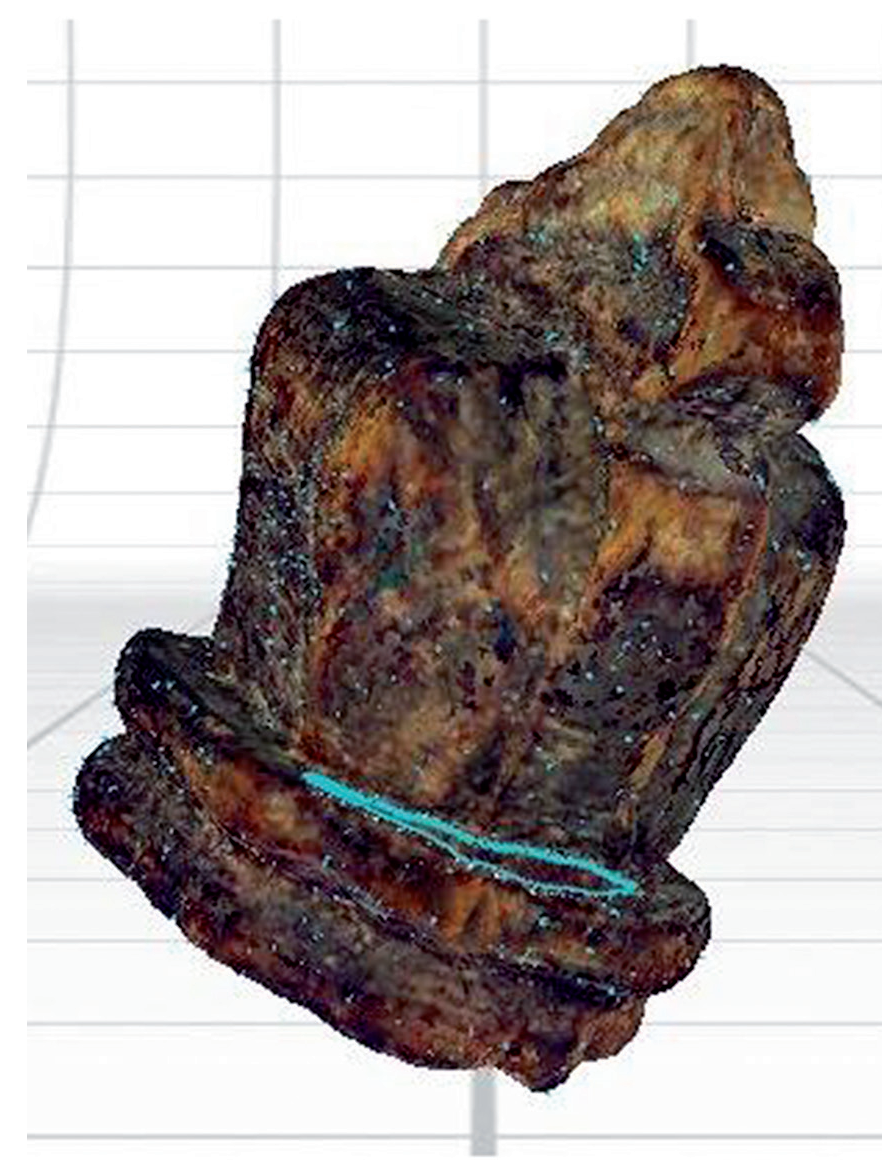

Obr. 16. Modrou farbou vyznačené diery v modeli, ktoré sa budú dopočítavat' (Kosmelová 2018, 56).

Fig. 16. Holes in mesh to be filled are marked in blue (Kosmelová 2018, 56).

súbor a jeho textúry. Pridružené súbory, z ktorých vznikol výsledný model je možné vymazat'. Čo sa týka vel'kosti modelov, prvý mal 212 MB no pri 3D skenovaní d’alších figúrok sme vel'kost̉ znížili na polovicu.

Proces vyhotovenia jednej naskenovanej figúrky trval približne 4 hodiny. Skenovanie 7 figúrok a ich editácia zabrala približne 35 hodín práce.

\section{Analýza vhodnosti použitých metód}

Pri dokumentácií artefaktov boli celkovo využité 4 metódy, ktoré budú následne zhodnotené s vyzdvihnutím ich pozitívnych a negatívnych aspektov. Dovolíme si upozornit, že táto komparácia je platná pre zvolené vybavenie, či už softvérové alebo hardvérové.

Výhody kresby spočívali vo finančnej nenáročnosti potrebného vybavenia a v uskladnení vyhotoveného záznamu. Ako výhodu môžeme vyzdvihnút prepracovaný systém značiek a schém využívaných pre úpravu povrchu 
4.

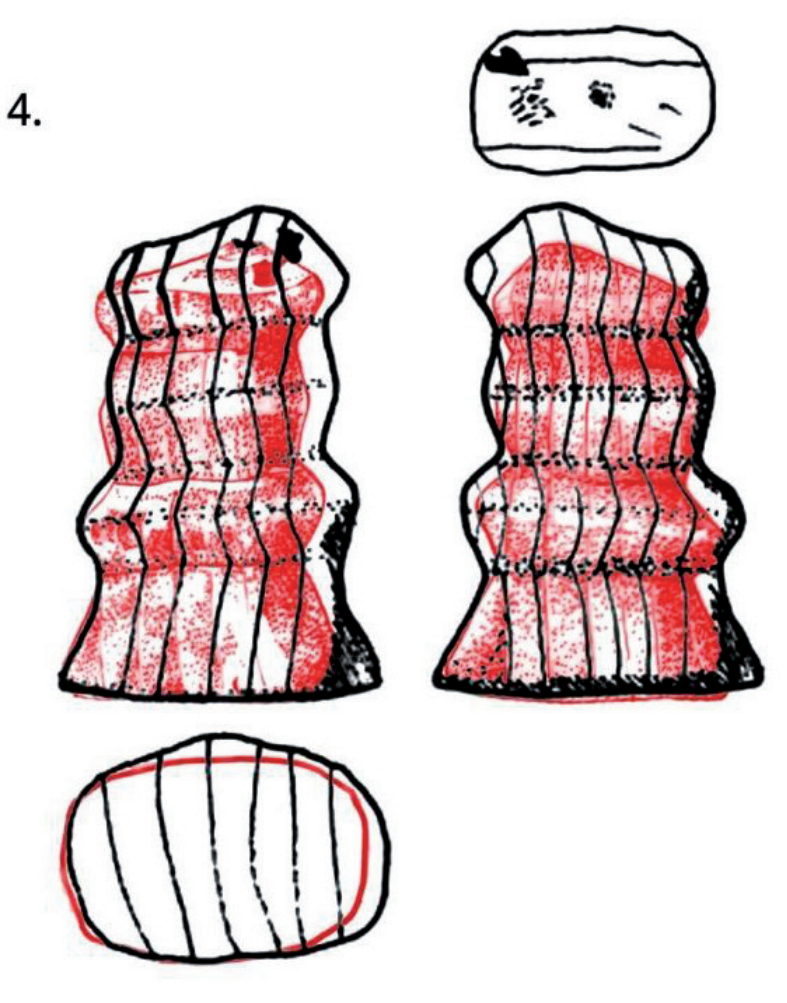

0

$5 \mathrm{~cm}$

Obr. 17. Znázornenie subjektívnych nepresnosti pri kresbe a chýb v meraní artefaktov. Na figúrke je tiež viditel'ný rozdiel v skúsenosti s technikou kresby, ktorá sa prejavuje hlavne na tieňovaní (Kosmelová 2018, 58).

Fig. 17. Inaccuracies and errors in artefact drawings caused by creator's subjectivity. There is visible difference in drawing technique which is noticeable at shading part (Kosmelová 2018, 58).

a tieňovanie, ktoré sú dohodnuté a platia prakticky skoro všade. Vel'kou výhodou je rozvinutie kresby do plochy, ktoré sa používa väčšinou pri keramike. ${ }^{11} \mathrm{~V}$ našom prípade sa jednalo o možnosṫ detailného prekreslenia a zväčšenia pekných detailov na figúrkach. Pozitívom je možnosṫ pripojit’ rezy predmetom, ktoré však nemusia byt $100 \%$ presné. Pri kresebnej dokumentácií je tiež možnost’ rekonštrukcie, ktorá je vyznačená odlišne od zbytku kresby. Väčšinou ide o odlíšenie prerušovanou čiarou.
Naopak vel'kou nevýhodou kresby je už spomínaná subjektivita, nepresnost̉ a prílišná schematizácia, ktoré súvisia hlavne so skúsenostami dokumentátora a so zložitostou kresleného tvaru. Ani skúsení kresliči sa mnohokrát nevyhnú subjektivizácií, pretože aj ked' sa snažia zachytit’ objekt čo najvernejšie so starostlivým meraním a vytrénovanou pozornostou, každý z nich vkladá do kresby svoj tzv. kresličský rukopis (Orton - Tyers -Vince 1993, 93). Aby sme názorne demonštrovali podiel subjektivity, kedy rovna- 
ká figúrka môže byt nakreslená úplne odlišne dvoma autormi pripájame porovnanie kresieb z roku 2015 a našich kresieb z roku 2018, na ktorých vidiet’ vel'ké odchýlky (vid' obrázok 17). Vo výsledku môžeme povedat', že kresba je vo vel'kej miere ovplyvnená osobou kresliča, aj ked' sa snažíme o čo najväčšiu objektivitu a presnost' v meraní. Vel'ké negatívum je nutná znalosṫ technického kreslenia a určitý talent, ktorý nie všetci archeológovia majú a u neskúsených kresličov je vel'ké riziko skreslenia. Ďalšia nevýhoda sa viaže ku publikácií kresieb, ktoré boli vyhotovené rôznymi autormi. V takomto prípade je len vel'mi tažké zabránit odlišnému štýlu, kvôli už spomínanému kresličskému rukopisu, ktorý má každý dokumentátor iný. Kresby tiež môžu pôsobit nesúrodo hlavne kvôli odlišnostiam v šrafúre, tieňovaní, hrúbke čiar a podobne. Pri meraní rozmerov figúrok bola zistená vel'ká nevýhoda pri kontakte s materiálom, kedy pri figúrkach z mäkkého dreva nemohol byt použitý profilovací hrebeň. Figúrke z kosti profilovací hrebeň ani použitie dentálneho vosku ku získaniu jej profilu nevadilo. Drevené figúrky vyžadovali extrémne opatrnú manipuláciu, pretože by ocelové zúbky hrebeňa mohli v nich zanechat odtlačky, alebo ich úplne zničit. Hrebeň bol teda ručne tvarovaný tak, aby vôbec neprišiel do kontaktu s figúrkou, čo bolo časovo dost' náročné a zdíhavé. Pri kreslení drevených figúrok nebol vôbec použitý vosk, kvôli možnému zanechaniu stôp na dreve. Ako nevýhodu tiež uvádzame celkom pracný spôsob vyhotovenia a čas neskúseného kresebného dokumentátora, ktorý predstavuje 18 hodín čistého času.

Pri fotografií máme možnost’ s dobrým nasvietením objektívne zachytit daný artefakt aj s jeho farebnostou a textúru. Ako nevýhoda sa všeobecne uvádza vysoká cena fotoaparátov a príslušenstva, no z reálneho pohladu je tento argument irelevantný, pretože v dnešnej dobe má už každá inštitúcia, ústav alebo múzeum vlastný kvalitný fotoaparát. Rovnocennost’ zo- brazenia je uvádzaná ako d’alšia nevýhoda fotodokumentácie. Zástancovia tradičnej kresby sa zhodujú väčšinou na tom, že fotografia nerozlišuje to, čo je podstatné a nepodstatné. Ako príklad uvediem rytinu kozorožca na bridlicovej doske, kde je na kresbe zretel'nejšie vidiet' rytinu, pričom na fotografíi je pozorovatelná len nevýrazne (podla Valoch - Lázničková - Galetová 2009, 121). Dovolili by sme si uviest protiargument a to ten, že nie je možné, aby bol kresebný dokumentátor vzdelaný vo všetkých odvetviach archeológie a na základe toho si nemyslíme, že každý kresebný dokumentátor má „cit“ na zvýraznenie onej podstatnej informácie pri všetkých druhoch artefaktov. Ide teda znovu o subjektívne vnímanie dokumentátora, pričom fotografia dokáže zachytit daný predmet vo vysokom rozlíśení relatívne bez skreslenia a pomocou grafických softvérov môžu byt detaily následne zvýraznené.

Metóda 3D fotogrametrie je vhodná ako pre dokumentáciu terénnych situácií a väčších objektov, tak aj pre menšie, ktoré vyžadujú detailnú dokumentáciu. Je tiež vhodná pre zaznamenanie jednoduchých rovín, ako aj pre členité artefakty s množstvom výstupkov. Vel'kou výhodou tejto metódy pri dokumentácií výskumov alebo väčších objektov sú poznatelné časové úspory v teréne. Opät dôležitá výhoda pre nedeštruktívny prieskum spočíva $\mathrm{v}$ získaní rezov, objemu a iných dát bez fyzického dotyku s predmetom. Medzi jej prednosti patrí vysoká presnost.

Do potencionálnych nevýhod patrí cena. Nehovoríme však explicitne o nevýhode, pretože cena sa mení v závislosti od toho, aký softvér je využívaný. Pri využití frivéru môže tak byt rovnaká ako pri fotodokumentácií. Pri využití platených profesionálnych softvérov je cena pochopitelne vysoká.

Medzi nevýhody patrí náročnost’ na výpočtovú silu používaného hardvéru. $\mathrm{V}$ našom prípade výpočty prebiehali celkovo na troch 

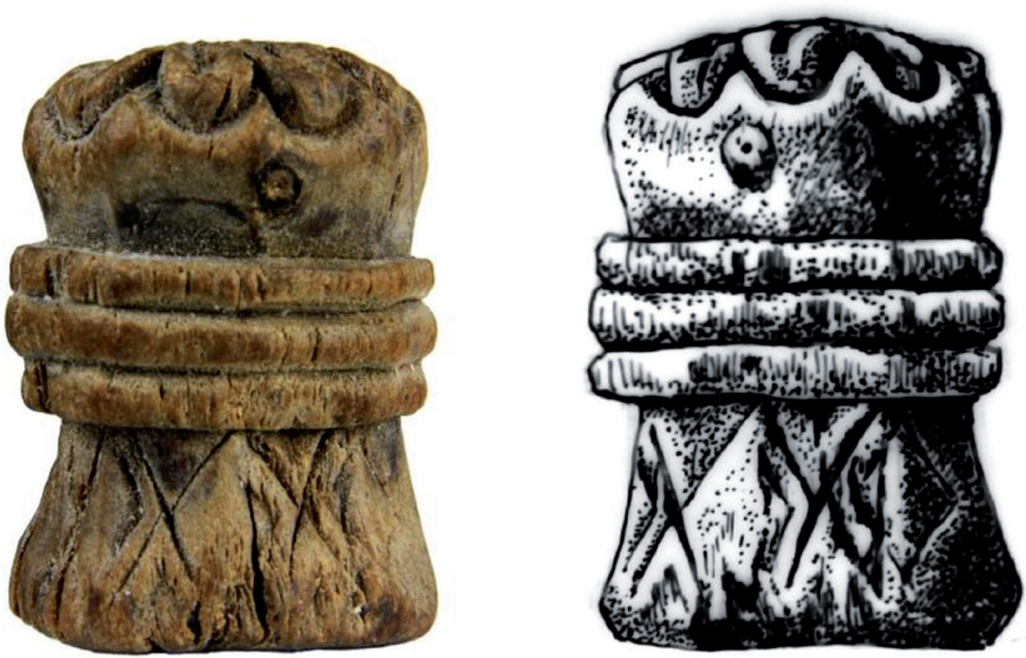

Obr. 18. Znázornenie zahĺbených rýh na figúrkach zretel'ne viditel'ných na fotografií v porovnaní s kresbou. Foto: N. Kosmelová, kresba: L. Chatrná 2015 (Kosmelová 2018, 59).

Fig. 18. Engraving visualisation in comparison of a photograph and a drawing. Photo: N. Kosmelová, drawing: L. Chatrná 2015 (Kosmelová 2018, 59).

\begin{tabular}{|c|c|c|c|c|}
\hline & Kresba & Fotografia & 3D Fotogrametria & 3D Skenovanie \\
\hline Potrebné vybavenie & - & $\bullet$ & $\bullet$ & $\bullet \bullet \bullet$ \\
\hline Potrebné znalosti dokumentátora & $\bullet \bullet \bullet$ & $\bullet \bullet$ & $\bullet \bullet \bullet$ & $\bullet \bullet$ \\
\hline Čas vyhotovenia & $\bullet \bullet \bullet$ & - & $\bullet$ & $\bullet \bullet$ \\
\hline Finančná náročnost' & - & $\bullet$ & $\bullet$ & $\bullet \bullet \bullet$ \\
\hline Objektivita & - & $\bullet$ & $\bullet \bullet \bullet$ & $\bullet \bullet$ \\
\hline Presnost $t^{\prime}$ & - & $\bullet \bullet \bullet$ & $\bullet \bullet \bullet$ & $\bullet \bullet$ \\
\hline Reálna podoba s originálom & $\bullet$ & $\bullet \bullet \bullet$ & $\bullet \bullet \bullet$ & $\bullet \bullet$ \\
\hline Možnost' rekonštrukcie & $\bullet$ & - & $\bullet \bullet \bullet$ & $\bullet \bullet \bullet$ \\
\hline Rezy predmetom & $\bullet \bullet$ & - & $\bullet \bullet$ & $\bullet \bullet \bullet$ \\
\hline
\end{tabular}

Tab. 5. Tabul'ka znázorňuje graficky podkapitolu Analýza použitých metód. Bola vytvorená na základe empírie autorky, ktorá bola do každého odvetvia zaškolená odborníkom. ${ }^{12}$ Tabul'ka je len ilustračná, pracuje s dostupným vybavením Ústavu archeologie a muzeologie, Laboratoře morfologie a forenzní antropologie a nesnaží sa tak postihnút' všetky možnosti daných metód (Kosmelová 2018, 61).

Vysvetlivky: • nízka náročnost'/ presnost', • - stredne vel'ká náročnost'/presnost', • • vel'ká náročnost'/ presnost'.

Tab. 5. Table with graphic representation of the subchapter Analysis of the Methods Used results. This only reviews author's experience with equipment and methods used in 3D laboratory of Department of Archaeology and Museology and Laboratory of morphology and forensics anthropology. sophistication • high sophistication. (Kosmelová 2018, 61). 
notebookoch; Lenovo IdeaPad B580, Lenovo IdeaPad Z560, no pre ich nedostačujúci výkon bol následne zvolený notebook HP EliteBook 8770 w. Proces nafotenia a samotné modelovanie aj s úpravami každej figúrky zabralo na prvých dvoch notebookoch 50 hodín. Celkový čas je opät relatívny, pretože závisí na výpočtovej sile. Pri vyhotovení všetkých výpočtov na notebooku HP EliteBook 8770 w by mohol byt čas výpočtu neporovnatelne nižší, odhadujúc na 8 hodín celkového času aj s nafotením všetkých figúrok a úpravou.

Poslednou použitou metódou je 3D skenovanie. Výsledný trojrozmerný naskenovaný model spracovaný $\mathrm{v}$ programe NextEngine ScanStudio je o niečo viac zahladený ako by bolo potrebné. Program totižto spriemeroval všetky 3D skeny dohromady a vznikol model s menším rozlíšením. Nextengine má tiež tendenciu veci prifukovat’ a modely sú objemovo najväčšie.

3D Skener NextEngine fungoval relatívne dobre na drevené figúrky, tiež na figúrku z kosti a všeobecne na kostrové pozostatky. Špecificky nie je moc dobrý na niektoré tmavšie materiály $\mathrm{s}$ podpovrchovým trieštením. Je to ale prípad od prípadu.

Vzniknuté modely neboli síce naskenované úplne dokonale, ale väčšinou chýbali skôr detaily. Nestalo sa, že by bolo miesto, ktoré by úplne chýbalo. Miestami bola siet̉ modelu dierkovaná, pretože sa na figúrkach vyskytujú jemné štrbinky, kde sa laser nemal ako chytit a tak vznikli drobné medzery. Figúrky sú však dost’ nepravidelné, takže tento problém nevznikal často. Poznatel'ne horšie je to pri 3D skenovaní symetrických objektov.

Nevýhodu vidíme v nie úplne dokonalej textúre, ktorá sa však dá upravit či zosvetlit externe $\mathrm{v}$ Photoshope ako textúrová mapa. Vzniknutá pôvodná textúra sa nedá porovnat s 3D fotogrametriou, pretože je miestami matná a flakatá.
Medzi najvýraznejšiu nevýhodu 3D skenovania je práve cena 3D skenerov, ktorá sa pohybuje v radách od $1000 €$ pre dostatočne kvalitné a presné skenery. Samozrejme platí, čím viac profesionálny skener, tým stúpa aj jeho cena. Proces vyhotovenia všetkých 7 figúrok síce trval 35 hodín, čo je v porovnaní s kresbou o 17 hodín viac, no musíme si uvedomit, že proces skenovania nevyžaduje neustálu prítomnosṫ dokumentátora a reálny čas, ktorý človek strávi nastavovaním 3D skenera je pri 17 hodinách práce kreslenia zanedbatel'ný.

\section{Výsledky a kritika staršej metódy spracovania}

Pre demonštráciu rýchleho pokroku v technológiách sa autori tiež zamerali na porovnanie starších a novších trojrozmerných dát z 3D fotogrametrie a 3D skenovania. Staré modely figúrok boli počítané pomocou 3D Software object Modeller (spoločnosti Creative Dimension Software Limited) v roku 2012 a skenované pomocou 3D skenera Mephisto EOSScan (Innovative Solutions) v roku 2014. ${ }^{13}$ Pre zhotovenie nových dát pre 3D fotogrametriu bol využitý už spomínaný softvér Agisoft Photoscan a na skenovanie 3D skener NextEngine ScanStudio. Aj napriek tomu, že od zhotovenia starších 3D modelov prešiel pomerne krátky čas, môžeme vidiet markantný posun $\mathrm{v}$ technológiách a ich výstupoch.

\section{D Fotogrametria}

Staršie modely sa skladajú z výrazných geometrických obrazcov. Plocha povrchu je členená na jednotlivé rovné geometrické plôšky a nepôsobí plynulým ani akurátnym dojmom. Celkovo však modely pomerne dobre kopírujú celkový tvar figúrok. Nepresnosti sa prejavujú hlavne po 
priblížení a pri pohlade na detail. V celkovom pohlade vyčnievajú hlavne prílišné ostrosti hrán povrchových plôch, ktoré napomáhajú nerealistickému lomu svetla a príliš nápadnej geometrickej hre tieňov. Zanikajú v nich tiež jednotlivé drobné detaily figúrok.

Textúry vykazujú dobrú kresbu detailov dreva. Pri bližšom pohlade sa rapídne znižuje kvalita textúry, kedy vychádza najavo ich neostrost’ a malé rozlíšenie, ktoré tak celkovo nedovoluje príliš detailnú prácu s modelmi figúrok.

Obecne by sa dalo povedat, že nové modely vykazujú vyšší stupeň detailov aj presnosti a nie sú tak geometrické. Jasnost textúr zase hovorí v prospech starších modelov, ale to môže byt dané aj tým, že v dobe vyhotovenia prvej verzie modelov boli figúrky svetlejšie a až neskôr došlo $\mathrm{k}$ ich stmavnutiu a tým strate detailov pri fotodokumentácií. Staršie textúry vykazujú horšiu kvalitu a ostrost', v porovnaní s novo vyhotovenými.

\section{D Skener}

Staršie skenovanie ukazuje tvarovo velmi presné modely figúrok, zobrazenie detailov na vysokej úrovni, vrátane drobných nuáns. Drobné hrany detailov sú však často príliš zagulatené, čo vo výsledku môže pôsobit umelo, a nepripomínat figúrky ručne vyrobené z dreva. Novo vyhotovené modely majú o niečo vyššiu presnost’ hrán, výsledok viac zodpovedá realite a model vecne zachycuje skenovanú skutočnosté.

Staršie textúry vykazujú vysokú kvalitu rozlíšenia a ostrosti, ale strácajú na detaile. Otázku vyvoláva aj odlišné farebné tónovanie figúrok, ktoré sa od starších fotogrametrických textúr nelíši len tmavšími odtieňmi, ale všeobecne inou farbou, čo je dané iným nasvietením artefaktov pri fotografovaní. Nové textúry zo skenera vykazujú povrchové závady, farebné nepresnosti a chyby. Textúra má adekvátne rozlíšenie, ale miera chýb ju činí takmer nepoužitel'nú.

\section{D Fotogrametria vs. 3D Skener}

Textúra pri 3D fotogrametrickej metóde dáva velmi solídny povrch s dobrou kresbou detailov, ostrostou a rozlíšením. Naproti tomu, figúrky z 3D skenera majú vel'ké množstvo chýb, takže textúra sa nedá bez zásahu v externom programe (PhotoShop) použit pre účely skúmania predmetu. Geometria a presnost' modelov sú vel'mi podobné. 3D fotogrametria zachytáva viac povrchových detailov a nerovnosti. Povrch od 3D skenu je hladší. Naproti tomu dokáže metóda skenovania zachytit hlbšie nerovnosti na figúrke vernejšie než metóda fotogrametrická. Model vyhotovený pomocou 3D skenu tak vykazuje hlbšie zárezy a väčšiu hĺbku povrchového reliéfu oproti 3D fotogrametrii.

\section{Porovnanie pomocou CloudCompare}

Pre porovnanie použitých metód dokumentácie archeologického artefaktu bol použitý aj vol'ne šíritelný program CloudCompare, verzia 2.9.1. ${ }^{14}$ Ten je primárne určený pre porovnávanie dvoch referencovaných mračien bodov. Výsledky z programu pomôžu pri všeobecnom zhodnotení jednotlivých metód vyhotovenia modelu archeologického artefaktu. Do prostredia programu boli nahrané dva modely rovnakej figúrky (pre potreby tejto kapitoly budeme demonštrovat’ figúrku č. 1) - jeden fotogrametrický, jeden vytvorený pomocou laserového skenovania. Modelom bola zjednotená mierka (funkcia Match scales), potom boli umiestnené zhruba cez seba (Match bouncing-box centers) a nakoniec boli presne referencované (Fine registration). V niektorých prípadoch bolo nutné kroky opakovat, aby došlo k dostatočne presnému výsledku.

Po detailnom referencovaní modelov bol vykonaný výpočet rozdielového rastra oboch 

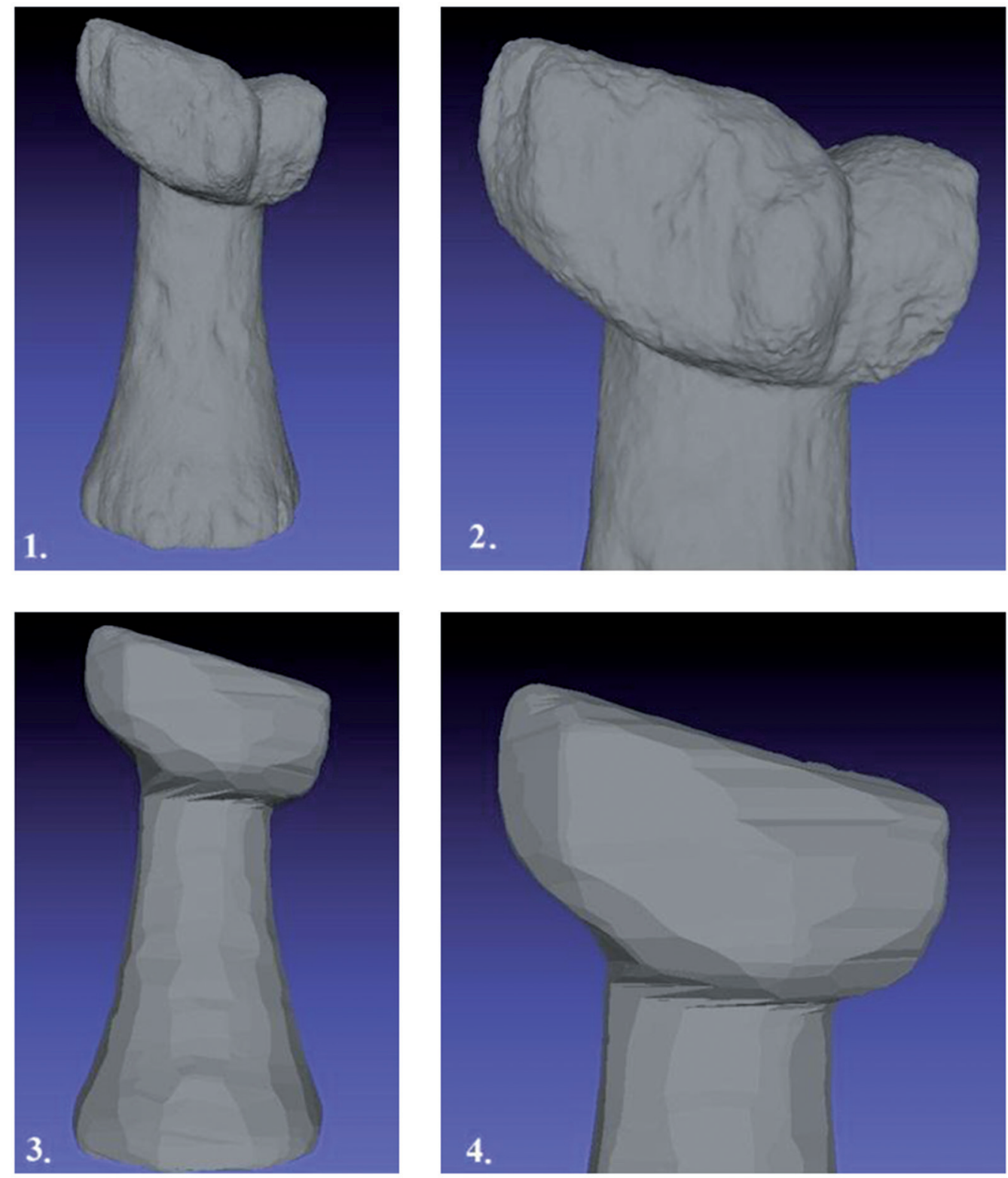

Obr. 19. Porovnanie starých a nových modelov bez textúry na figúrke č. 2 , ktorá bola vybraná ako reprezentatívna. 1. Nový model figúrky, 2. Detail nového modelu figúrky, 3. Starý model figúrky, 4. Detail starého modelu figúrky (Kosmelová 2018, 63).

Fig. 19. Picture comparing old and new models without texture on chess piece No. 2. 1. New mesh 2. New mesh closeup 3. Old mesh 4. Old mesh closeup (Kosmelová 2018, 63). 

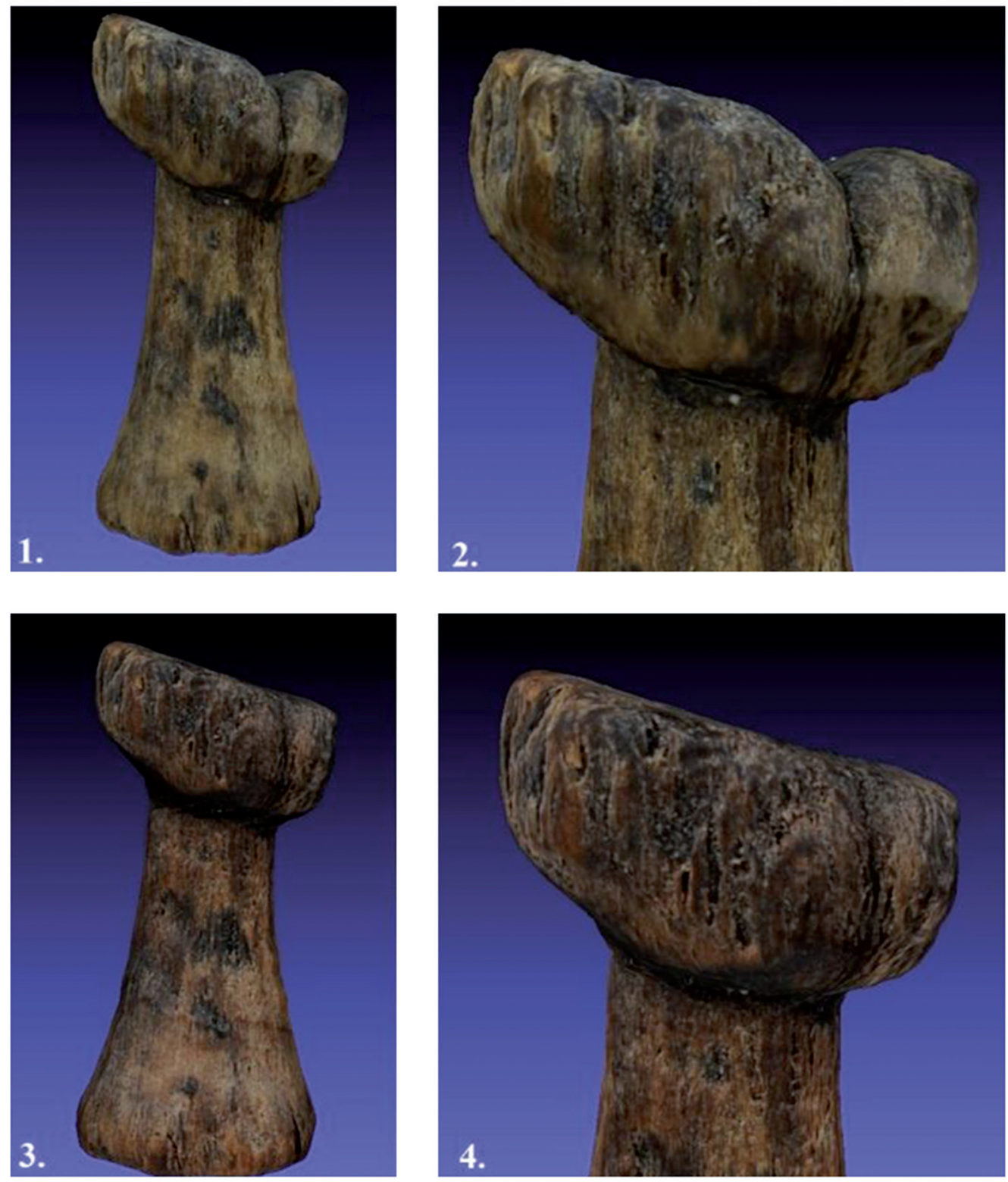

Obr. 20. Porovnanie starých a nových modelov s textúrou na figúrke č. 2, ktorá bola vybraná ako reprezentatívna. 1. Nový model figúrky, 2. Detail nového modelu figúrky, 3. Starý model figúrky, 4. Detail starého modelu figúrky (Kosmelová 2018, 63).

Fig. 20. Picture comparing old and new models with texture on chess piece No. 2. 1. New mesh 2. New mesh closeup 3. Old mesh 4. Old mesh closeup (Kosmelová 2018, 63). 

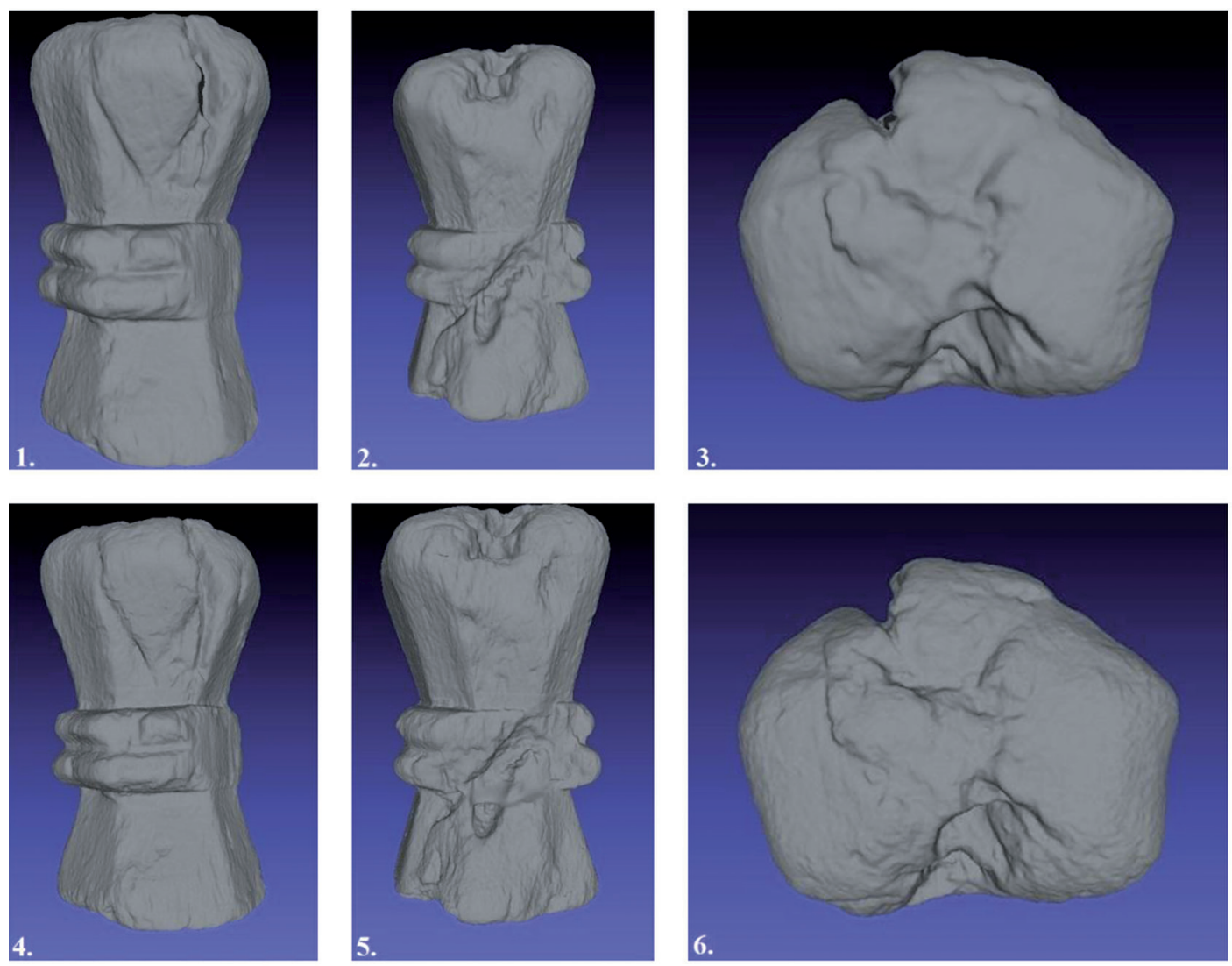

Obr. 21. Porovnanie starých a nových modelov bez textúry na figúrke č. 5 , ktorá bola vybraná ako reprezentatívna. 1. Nový model figúrky - predná strana, 2. Nový model figúrky - zadná strana, 3. Nový model hlavičky figúrky, 4. Starý model figúrky - predná strana, 5. Starý model figúrky - zadná strana, 6. Starý model hlavičky figúrky (Kosmelová 2018, 64).

Fig. 21. Picture comparing old and new models without texture on chess piece No. 5. 1. New mesh - front face 2. New mesh - backface 3. New mesh - chess piece head 4. Old mesh - front face 5. Old mesh - back face 6. Old mesh - chess piece head (Kosmelová 2018, 64). 

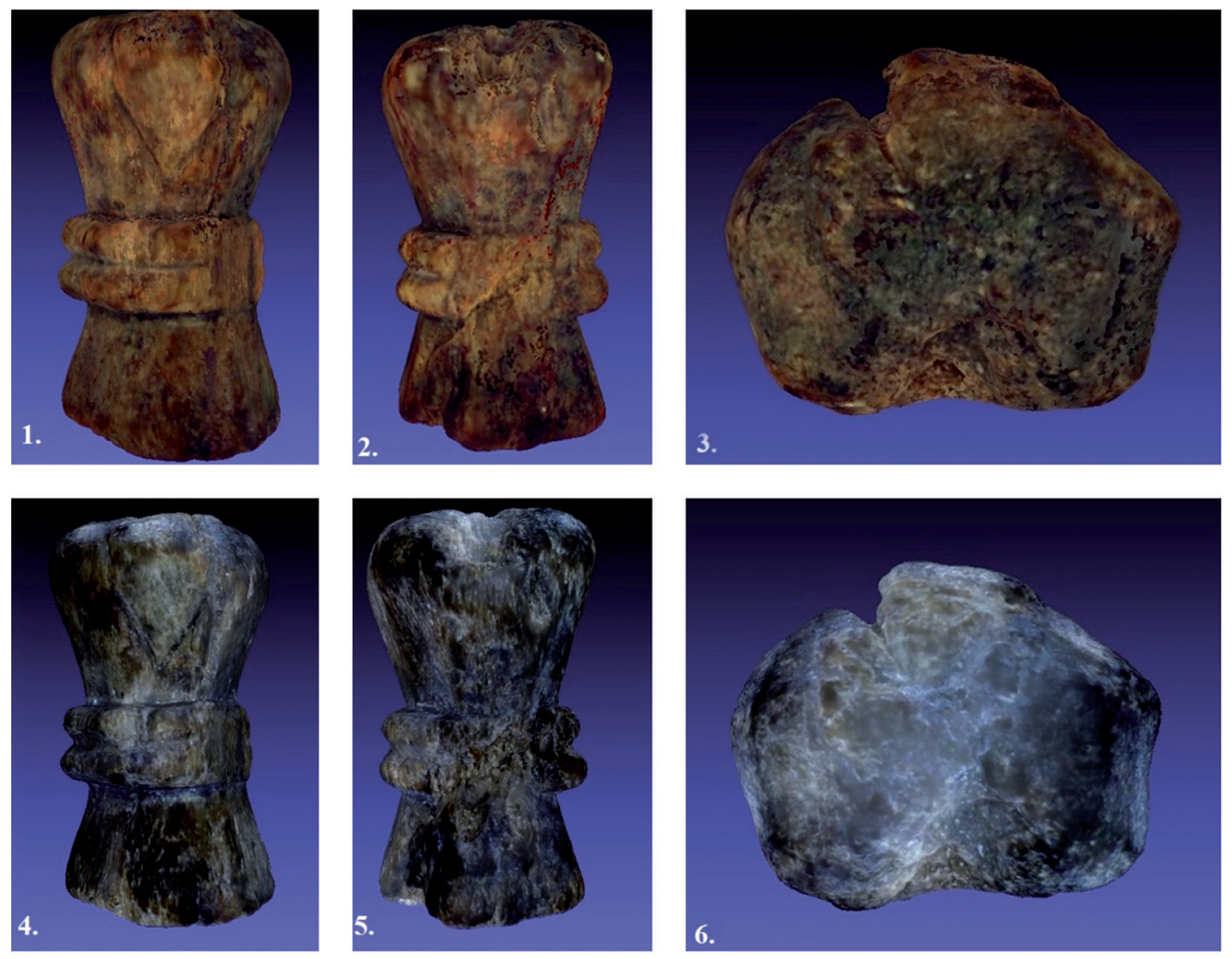

Obr. 22. Porovnanie starých a nových modelov s textúrou na figúrke č. 5, ktorá bola vybraná ako reprezentatívna. 1. Nový model figúrky - predná strana, 2. Nový model figúrky - zadná strana, 3. Nový model hlavičky figúrky, 4. Starý model figúrky - predná strana, 5. Starý model figúrky - zadná strana, 6. Starý model hlavičky figúrky (Kosmelová 2018, 65).

Fig. 22. Picture comparing old and new models with texture on chess piece No. 5. 1. New mesh - front face 2. New mesh - backface 3. New mesh - chess piece head 4. Old mesh - front face 5. Old mesh - back face 6. Old mesh - chess piece head (Kosmelová 2018, 65). 

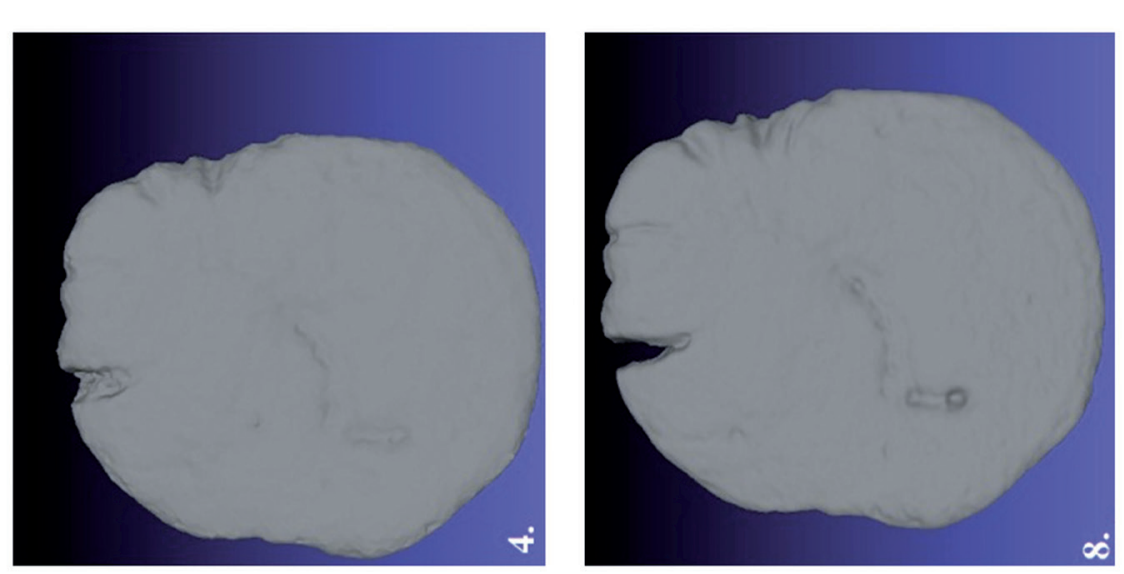

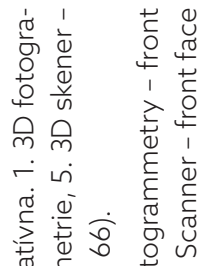

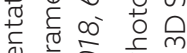

ปัँ

¿

Qิ1

ำ

- $\overrightarrow{1} 000$

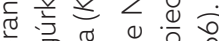

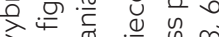

उ

ठ
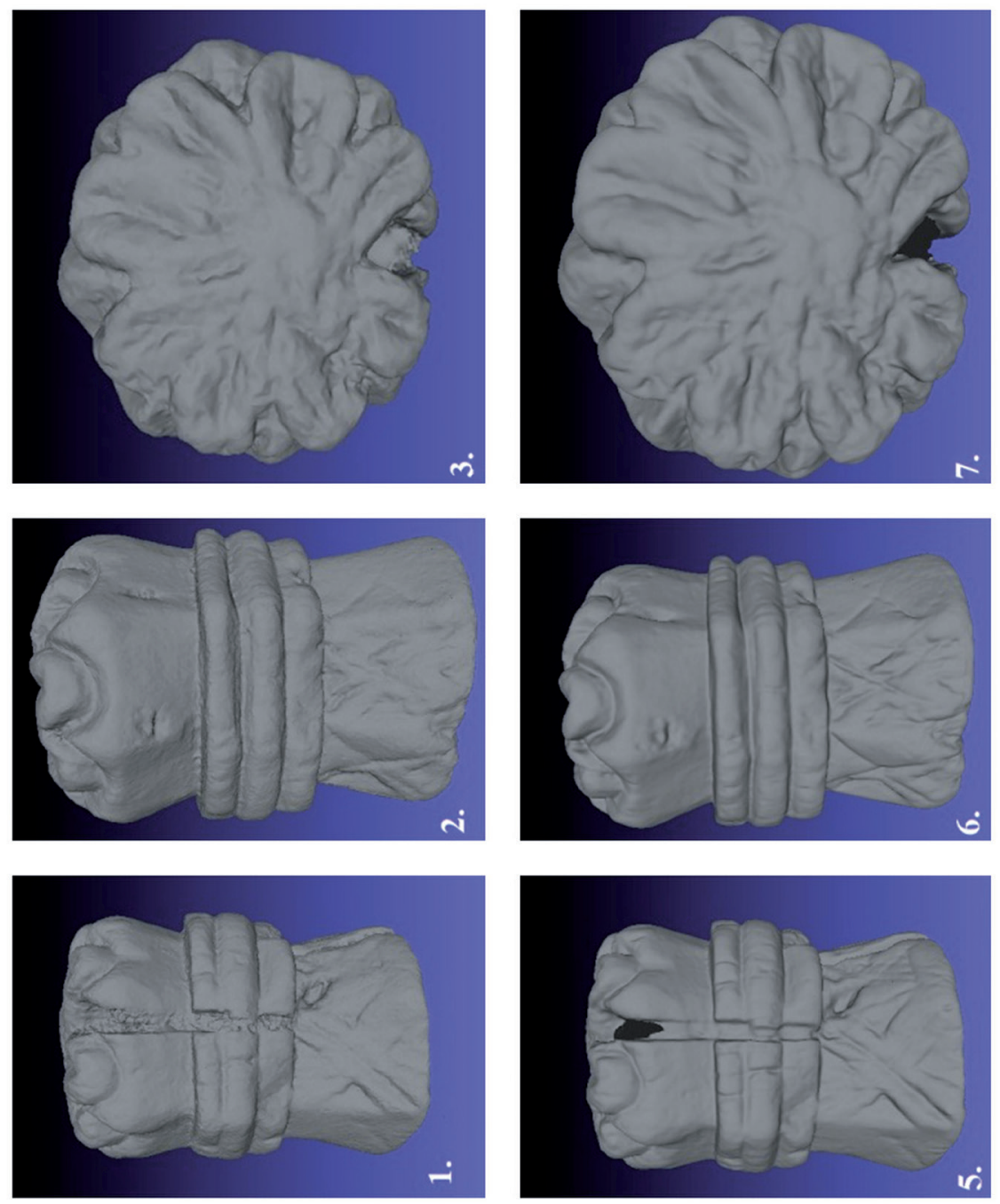

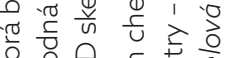

艺

$=N$ O

यं - 立 产

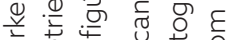

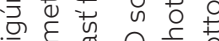

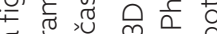

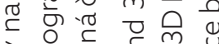

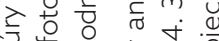

की

Q $m$ व 0

N $N$ 少

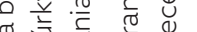

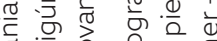

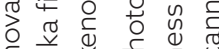

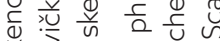

ज宁

D $N \in \stackrel{m}{*}$

nं

त

(1) त्व

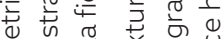

ह

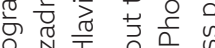

O

$+\frac{\sigma}{2} \pi m$

$m$ ब

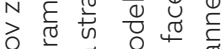

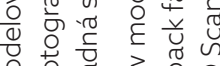

눈 0

ᄃ 1 เ

จํ.

ठิ

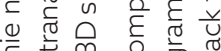

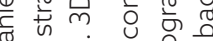

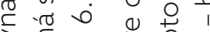

ठ ㄷำ

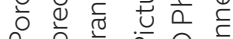

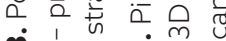

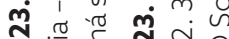

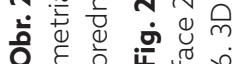



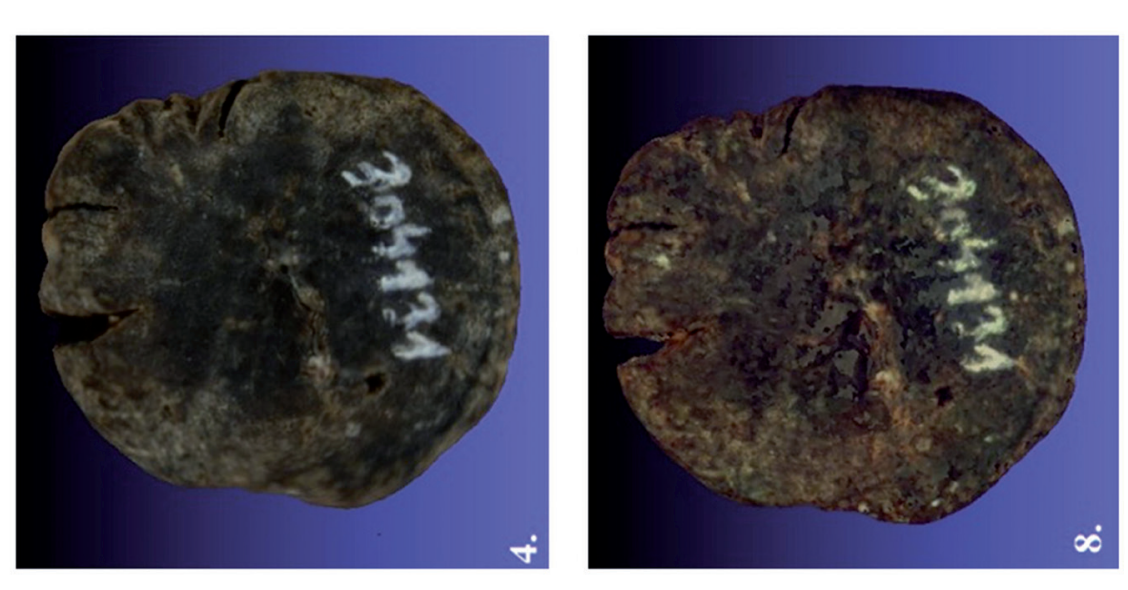

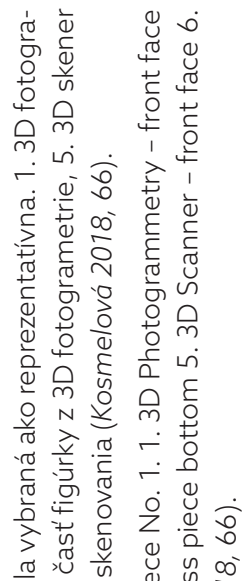
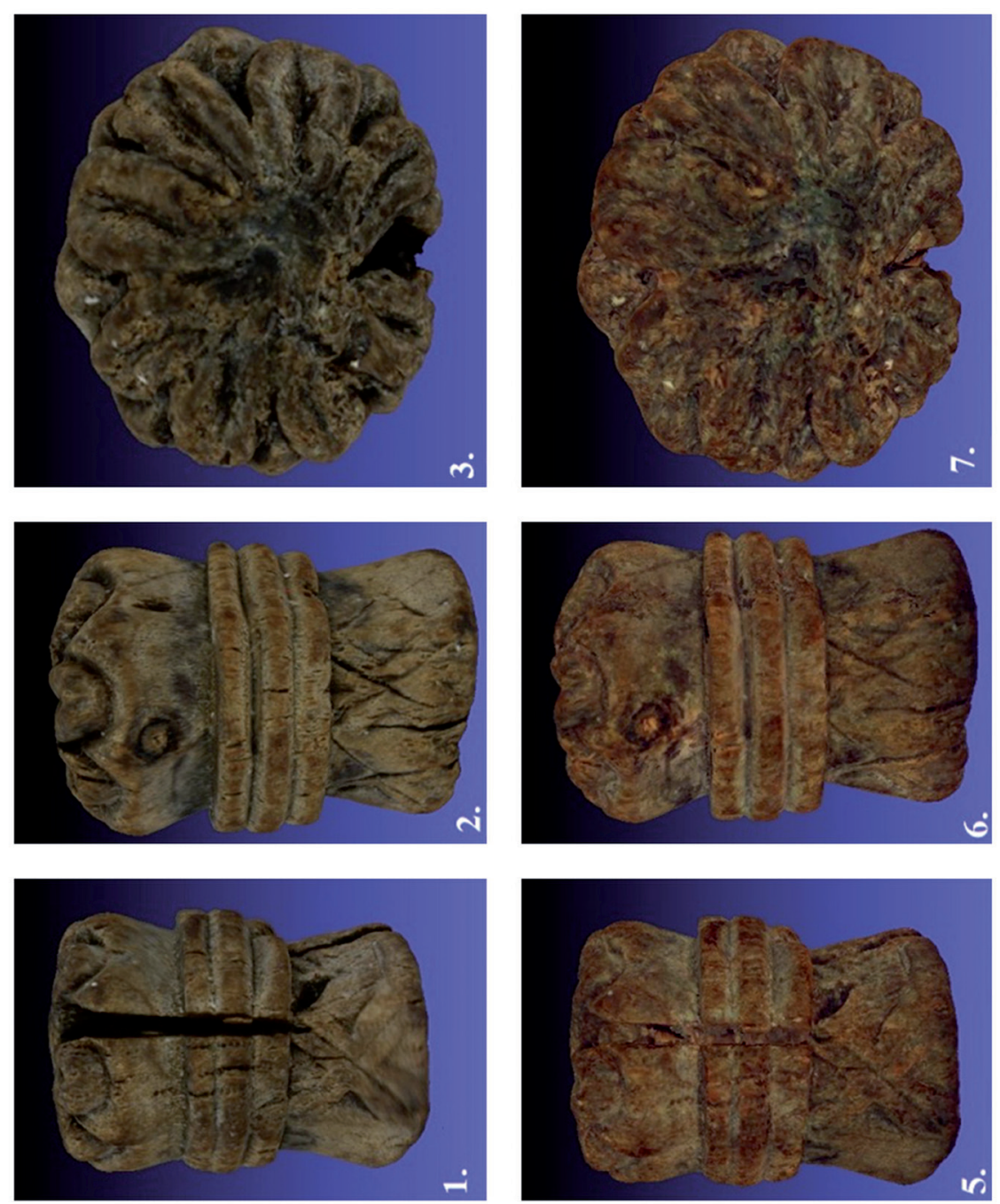

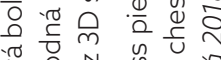

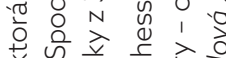

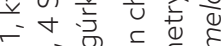

यें

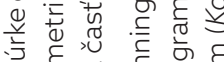

으 뜬

๘

ᄃ

운

产

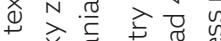

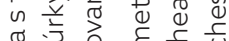

.

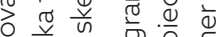

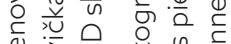

v

王 $N$ 兄兄

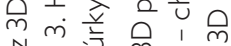

ช

. $\frac{1}{\sigma}$ 岳 ह

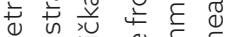

ह

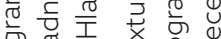

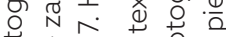

$+1 \hat{0}$

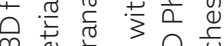

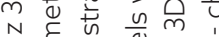

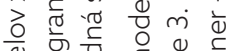

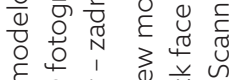

ह ᄂ

ป $m \div$ ต

ᄀน

ठำ ज

ब त्ष

它范 0 O

ฮ

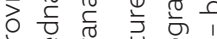

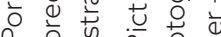

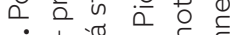

ป

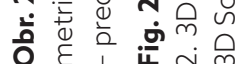




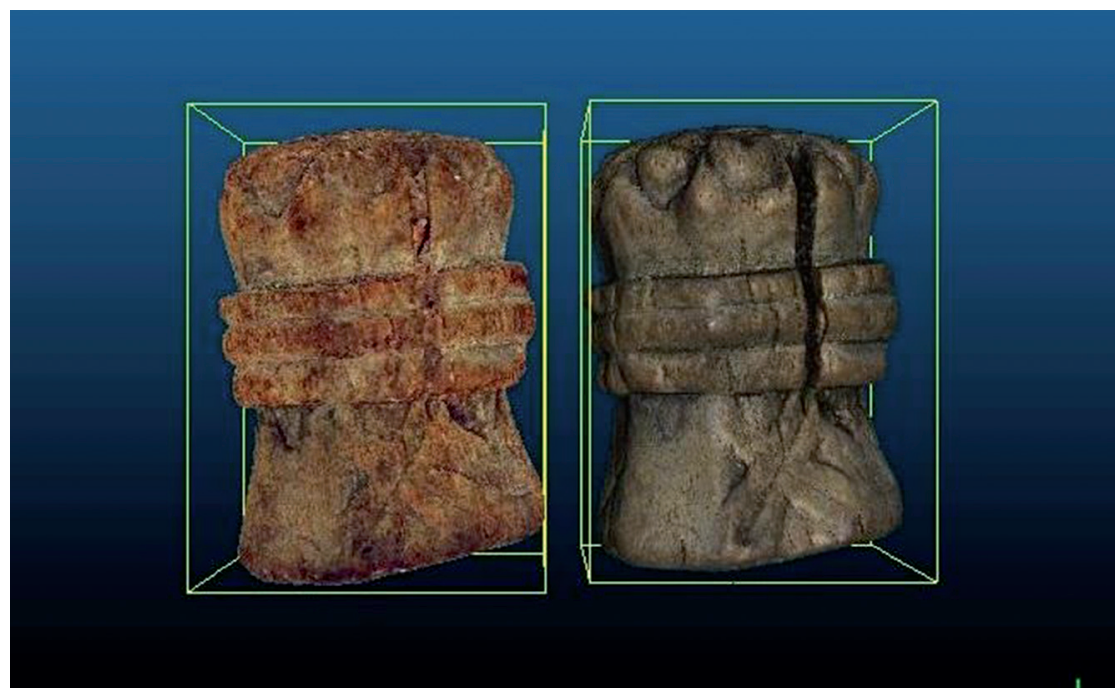

Obr. 25. Modely nahrané do prostredia programu CloudCompare, vl'avo sken, vpravo 3D fotogrametria (Kosmelová 2018, 67).

Fig. 25. Models imported into the CloudCompare software. Left from 3D scan, right made by 3D photogrammetry (Kosmelová 2018, 67).

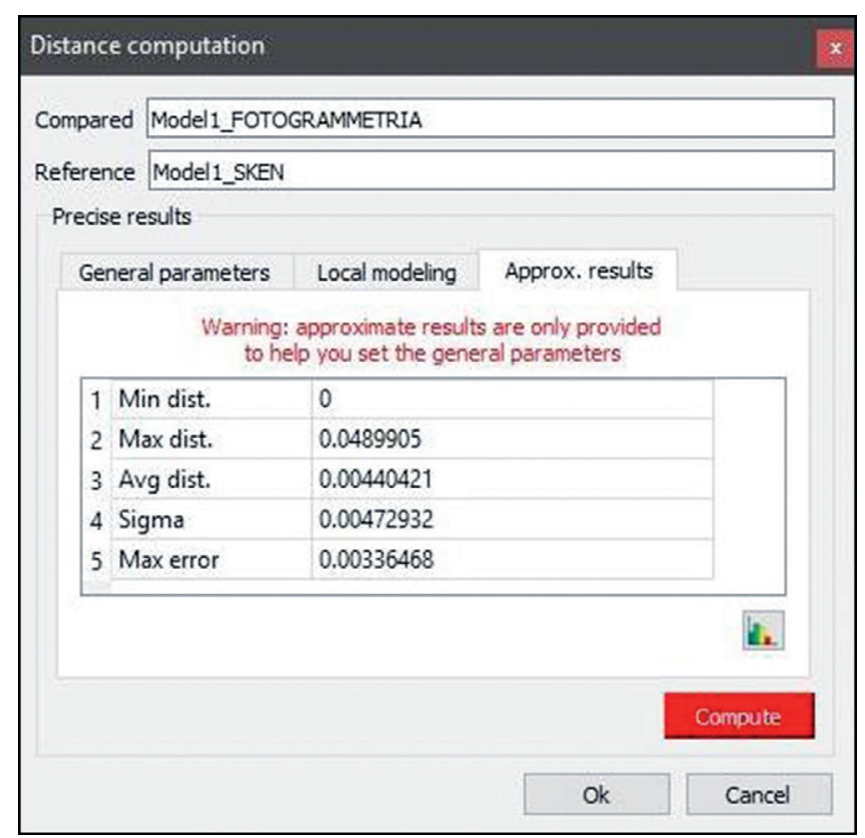

Obr. 26. Výpočet vzdialenosti povrchov oboch modelov (Kosmelová 2018, 68).

Fig. 26. Computing the distance between model surfaces (Kosmelová 2018, 68). 


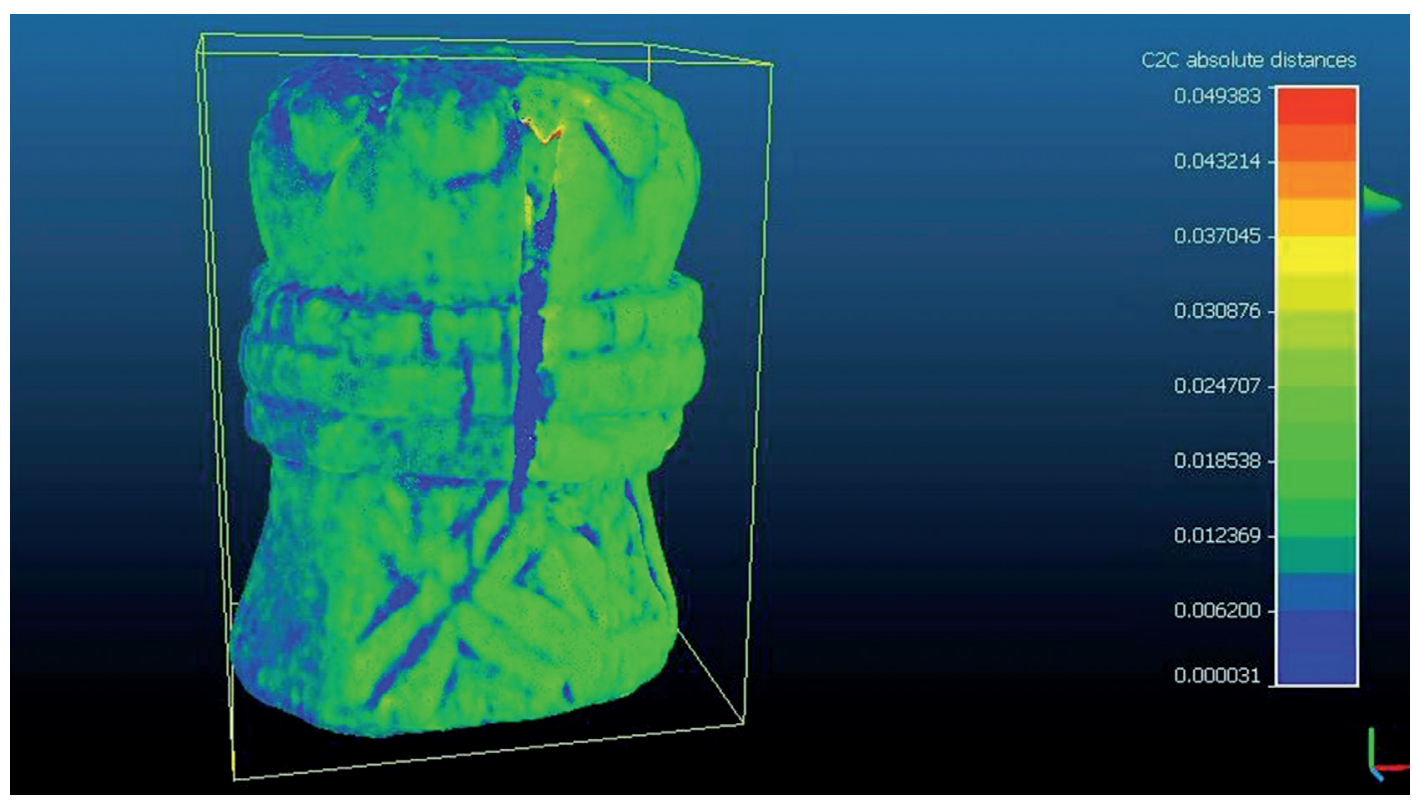

Obr. 27. Porovnanie povrchu modelov v programe CloudCompare. Modrá farba ukazuje, že model vyhotovený pomocou laserového skenovania vernejšie zachycuje híbku reliéfu povrchu figúrky (Kosmelová 2018, 68).

Fig. 27. Mesh comparison using CloudCompare software. Blue color indicates that $3 \mathrm{D}$ scanned mesh is more accurate in detail of depth (Kosmelová 2018, 68).

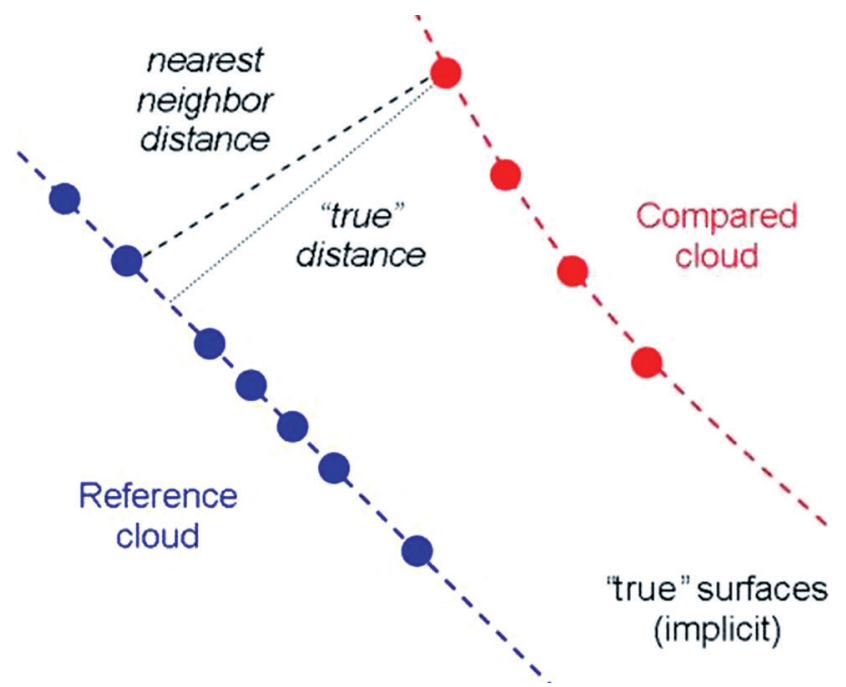

Obr. 28. Teoretická ukážka výpočtu vzdialenosti povrchu referencovaných modelov v programe CloudCompare (Kosmelová 2018, 69).

Fig. 28. Visualisation of cloud to cloud distance measurement principle using CloudCompare software (Kosmelová 2018, 69). 


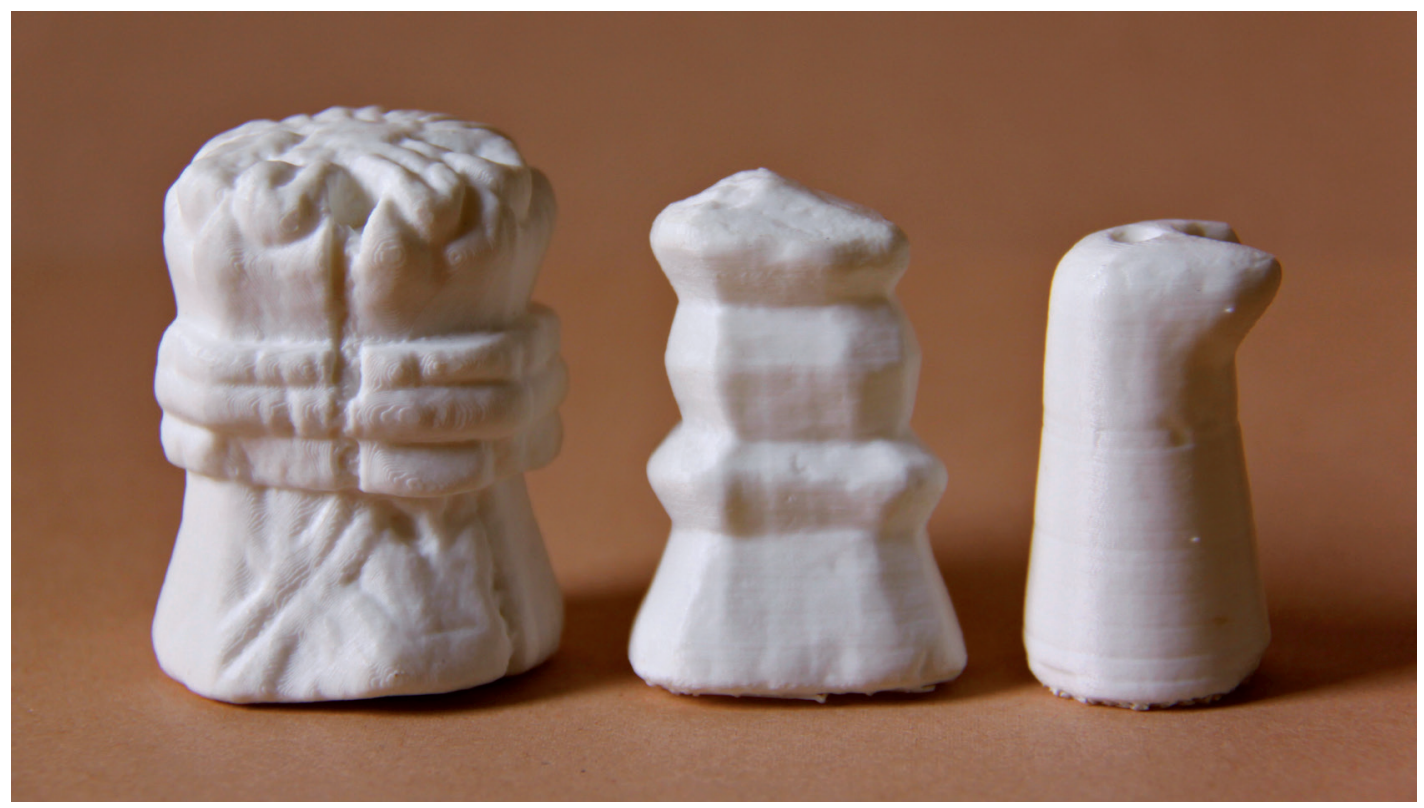

Obr. 29. Ukážka vytlačených 3D figúrok. Foto: N. Kosmelová.

Fig. 29. 3D printed chess pieces. Photo: N. Kosmelová.

mračien bodov (modelov) pomocou funkcie Cloud/Mesh Distance.

Najskôr bol zvolený referenčný a porovnávaný model. Ako referenčný bol vybraný model vyhotovený pomocou laserového skenovania. Následne automaticky prebehol približný výpočet vzdialenosti mračien bodov oboch modelov. Po nastavení parametrov výpočtu vzdialeností (nastavenie podla Boháč 2014, 58-61) bol vykonaný konečný výpočet a výsledok zobrazený pomocou farebného histogramu.

$\mathrm{Z}$ výsledkov porovnania modelov vyplýva pomerne vel'ká vzájomná presnoste oboch modelov. K najväčším chybám dochádza pri porovnaní hlbších miest na povrchu modelu. V miestach hlbších povrchových reliéfov je presnost' zachytenia híbky pomocou fotogrametrického modelu nižšia, než u modelov vyhotovených pomocou laserového skenovania, ktorý tak dokáže vernejšie zachytit geometriu povrchu figúrky v porovnaní so skutočnostou. Je to však za cenu niekol'konásobne vyššej dátovej náročnosti modelov.

\section{D tlač figúrok}

Figúrky boli experimentálne vytlačené na Ústave výpočetní techniky za odbornej pomoci Alexandra Kolovratníka. Tlač prebehla na 3D tlačiarni eDee (spoločnosti Ysoft). Tlačiareň je ovládaná cez integrovaný zatiahnutel'ný dotykový sedempalcový displej. Tlačiareň tlačí s Ysoftom certifikovaným PLA filamentom. Bohužial' nebolo možné využit iný filament, ktorý by imitoval materiál (drevo a kost'), z ktorého sú figúrky vyrobené. Niektoré figúrky museli byt tlačené ako dva modely, a až následne zlepené do jedného modelu, kvôli ich komplikovanejším tvarom. 


\begin{tabular}{|l|l|}
\hline Model & eDee \\
\hline Technológia tlače & FFF (Fused Filament Fabrication) \\
\hline Oblast' tlače & $150 \times 150 \times 150 \mathrm{~mm}$ \\
\hline Priemer trysky & $0,4 \mathrm{~mm}$ (predpokladaná životnost' 1500 h) \\
\hline Typ tiskovej podložky & Sklenená, vyberatel'ná \\
\hline Kalibrácia & Automatická \\
\hline Bezpečnostné prvky & Zámky dvierok, snímač tiskové podložky \\
\hline Rozmery celkom & $496 \times 414 \times 397$ mm \\
\hline Hmotnost' & 27,5 kg \\
\hline Doporučené prevádzkové podmienky & $15 \&-30^{\circ} \mathrm{C}\left(59-86^{\circ} \mathrm{F}\right)$, max. 60\% vlhkost' \\
\hline Napájanie & Externý zdroj napájania 24 V/3,75 A (90 W, vstup 230 V/110 V) \\
\hline
\end{tabular}

Tab. 6. Špecifikácia parametrov použitej 3D tlačiarne (Kosmelová 2018, 70).

Tab. 6. Technical parameters of the 3D printer used (Kosmelová 2018, 70).

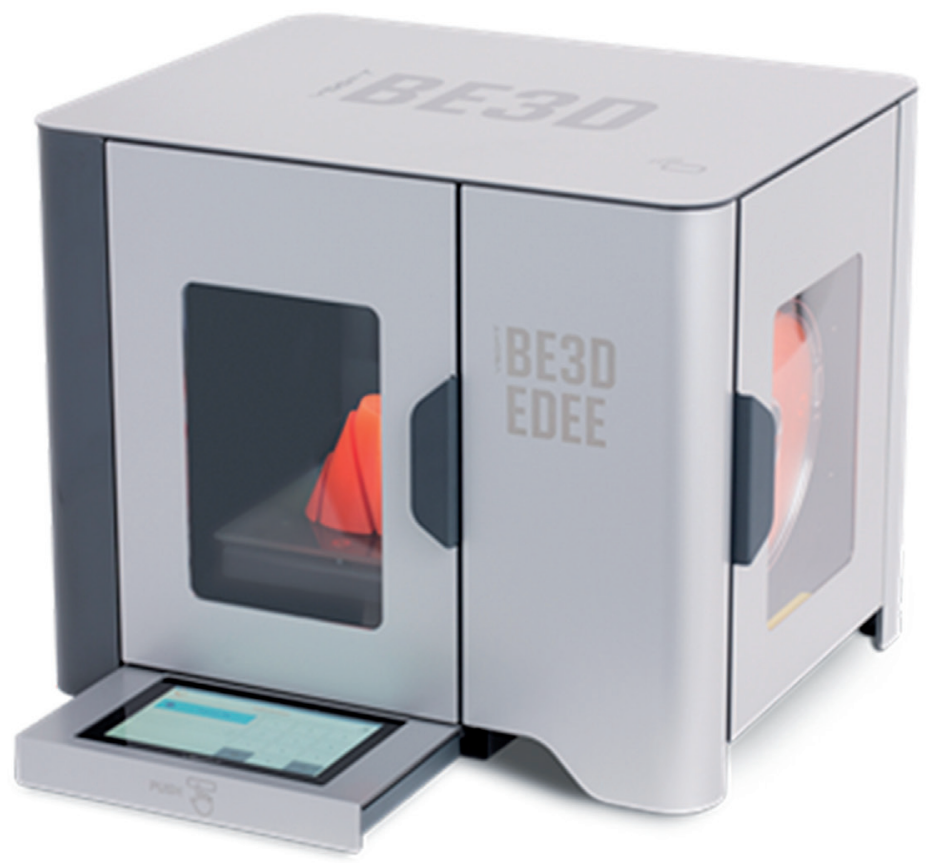

Obr. 30. Použitá 3D tlačiareň (Kosmelová 2018, 70).

Fig. 30. Used 3D printer (Kosmelová 2018, 70). 


\section{Diskusia}

V súčasnej dobe môžu archeológovia a nielen oni, zhromažd'ovat' obrovské množstvo 3D údajov. $\mathrm{S}$ ich narastajúcou popularitou a rozmachom je na mieste otázka ich trvácnosti, udržatelnosti a prístupnosti takéhoto typu a množstva dát.

Definíciu, ktorá by presne vystihovala, čo sú to trvácne dáta vôbec nie je lahké vytvorit'. Vo vel'mi zjednodušenom poňatí by sme mohli tvrdit, že sú to také dáta, ktoré pokračujú do budúcnosti (Richards - Rissetto - Schwerin 2017, 38). Táto definícia je však velmi otvorená a vedie k d’alším otázkam typu; ako dlho musia dáta pokračovat do budúcnosti, aby boli udržatel'né a trvalé? Môžu byt dáta uložené na zastaranom hardvéri označené ako trvácne? Ak by sme budúcnost̉ považovali za nekonečnú, dá sa vôbec takáto trvácnosṫ docielit? S popularizáciou 3D dát je tiež nutné mat̉ na pamäti otázky senzitivity dát, ich autorstva a ochrany

Vel'kost’ dát, ktoré musia byt’ uložené variuje na základe metódy, ktorou boli zozbierané. Požiadavky na skladovanie sa teda tiež rôznia a aby sme zabezpečili ich udržatel'nost', musia byt adekvátne skladované, čo predstavuje nemalú finančnú investíciu. Tu vyvstáva množstvo otázok, počínajúc tým $\mathrm{v}$ akom formáte budú dáta skladované, končiac tým, aké dáta budú vlastne uchovávané. V súčasnej dobe je evidovaných 366 koncoviek 3D formátov a tento počet stále nie je finálny, pretože podla nových potrieb užívatelov neustále rastie. ${ }^{15}$ Rôzne formáty ponúkajú rôzne výhody, ktoré si tvorca modelu volí na základe preferencií ešte pred tvorbou modelu. Na stránke tiež môžeme vidiet’ popularitu daných formátov zoradených zostupne, pričom v archeológií sú všeobecne najviac rozšírené formáty obj, .ply a .stl (Richards - Rissetto - Schwerin 2017, 40). ${ }^{16}$ Ďalšia komplikácia prichádza $\mathrm{s}$ rozhodnutím, aké dáta budeme skladovat. Rozlišujeme dva typy modelov; prvý predstavuje povedzme základný model, vyhotovený zo zozbieraných archeologických dát spracovaných skenerom, fotogrametriou a podobne. Do druhého typu spadajú rekonštrukcie a vizualizácie toho, ako daný objekt alebo artefakt mohol vyzerat' v minulosti (Richards Rissetto - Schwerin 2017, 39). Do oboch typov zasahuje svojimi rozhodnutiami človek, ktorý model vyhotovuje. Ku tomu sa viažu tri komplikácie, ktoré je nutné zohladnit pri výbere toho, aké dáta budeme uchovávat:

1) pre model existuje niekol'ko možných interpretácií,

2) samotné modelovanie zahŕňa súbor možnosti vychádzajúcich z paradat, ktoré sú pri procese tvorby modelov nejakým spôsobom korigované a upravované,

3) softvér využívaný pri tvorbe modelov je stále aktualizovaný a niektoré jeho nové verzie nie sú vždy kompatibilné so staršími verziami.

Je teda nutné ukladat všetky dáta a verzie programov? Hlavne s uchovávaním starších verzií softvérov je obrovský problém, pretože staršie verzie všeobecne obsahujú viac chýb, môžu byt bezpečnostným rizikom, ponúkajú menšie množstvo užívatel'ského obsahu a funkcií a hlavne nie je možné ich opätovná legálna inštalácia. Všetky tieto skutočnosti je potrebné diskutovat medzi odborníkmi, zainteresovanými inštitúciami a zriad’ovatel'mi. Bolo by potrebné vypracovat štandardy, podla ktorých bude rozhodnuté o uchovávaní dát. ${ }^{17}$

So skladovatel'nostou dát úzko súvisí aj ich prístupnost' a ochrana. Niektoré archeologické dáta sú citlivé a prístupnost̉ k nim si žiada otvorený prístup k údajom, ktoré často nemusia byt vhodné pre širokú verejnost'. Ich sprístupnenie môže napríklad viesṫ k vandalizmu, vykrádaniu, alebo $\mathrm{k}$ narušeniu duševného vlastníctva niektorých spoločenstiev (Frank - Kriesberg - Yakel - Faniel 2015, 2). Možné riešenie tohto typu 
problému opät ponúkol MayaArch3D Project, ktorý zvolil niekol'ko úrovní používatel'ského prístupu; verejnost', externý výskumník, interný výskumník, člen projektu MayaArch3D a administrátor. Pre verejnost’ sú viditelné len strážene archeologické lokality a naopak, až po zadaní prístupového hesla sú viditelné nechránené. Týmto spôsobom docielili požadovanú publikáciu a viditel'nost̉ dát. Každá z úrovní prístupu má pochopitelne iné právomoci počínajúc viditel'nostou vybraných lokalít, končiac prístupom ku všetkým dátam a možnostou ich editácie.

$\mathrm{S}$ problémom uskladnenia a prístupu k dátam sa v archeológií nestretávame len pri trojrozmerných dátach. $\mathrm{S}$ prezentáciou vizuálne zaujímavých dát a ich uskladnenia sa stretávame aj pri digitalizácií, ktorá sa v tomto storočí stáva viac a viac populárnou a hlavne potrebnou. Pod procesom digitalizácie chápeme sériu úkonov, kedy sa prevádzajú analógové dokumenty (obrázky, správy z výskumov, kresby profilov a podobne) do digitálnej podoby (Kenney - Rieger 2000, 8). V archívoch, múzeách, knižniciach a depozitároch sú uchovávané obrovské množstvá informácií, ktoré sú jednak tažko prístupné, jednak degradujú a hrozí ich strata. ${ }^{18}$

Vzhl’adom k ulahčeniu prístupu a kvôli zamedzeniu nenávratnej straty informácií v nich obsiahnutých sa pristupuje $\mathrm{k}$ vyhotoveniu ich digitálnej kópie. ${ }^{19}$ Obrovskou výhodou je práca s vel'kými súbormi, sprístupnenie tažko dostupných, krehkých, vzácnych a hlavne vzdialených dokumentov. Takýto prístup môže byt umožnený viacerým lud’om naraz a tak nie je pri nich nutná, častokrát dlhá čakacia doba. Pri potrebe je možné zdigitalizované materiály graficky upravit tak, aby vynikli dôležité informácie, farba, nápisy a podobne.

Problém s online alebo s digitalizovanými dátami, rovnako ako s niektorými trojrozmernými dátami, môže spočívat $\mathrm{v}$ nedôvere $\mathrm{v}$ ich autenticitu, ktorá môže byt pozmenená. Pomer- ne jednoduché a účinné riešenie s dôverou pri trojrozmerných modeloch môže byt farebné odlî̃senie originálnych dát od tých, ktoré boli domodelované na základe písomnosti, rôznych plánov a podobných informácií.

Prezentácia a popularizácia vedeckej práce a jej výsledkov je, dovolíme si tvrdit, jedna z najdôležitejších činností, od ktorej sa odvíja celkový pohlad na daný odbor medzi širokou verejnostou. Nemáme v úmysle popierat dôležitost publikácie odborných článkov a ich výsledkov, no v súčasnej dobe je nezmyselné predpokladat, že uloženie nájdených artefaktov do múzeí a publikovanie článku po niekol'kých rokoch od výskumu je dostačujúcim spôsobom prezentácie odboru. Klúčovým prvkom, na ktorý by sa mal dávat zretel' je vztah s verejnostou, teda komunikácia, ktorá smeruje väčšinou mimo odbornú skupinu ludí. Archeologické dáta vždy pritahovali záujem ludí a 3D prezentácia výsledkov môže tento záujem mnohonásobne prehĺbit. Cielom je docielit u l'udí tzv. Wow effect, niečím nezvyčajným a vizuálne atraktívnym (Plzák 2016, 25). To však neznamená, že takáto forma podania výsledkov nemôže obohatit aj členov profesnej sféry, ktorí si medzi sebou môžu napríklad preposielat skúmané artefakty v zlomkovom čase. ${ }^{20}$ Trojrozmerné dáta umožňujú rýchly prístup, analýzy, ktoré by bolo nereálne vykonat na originálnom artefakte a pomerne dobrú manipuláciu s predmetmi. Zaujímavú možnost̉ predstavuje domodelovanie poškodených predmetov, kedy môžu byt vymodelované ich jednotlivé časti, následne spojené a pomocou 3D tlačiarne vytlačené. Aplikácia týchto inovatívnych metód zberu informácií môže byt tiež využitá pri archeologických výskumoch a ich priebežnej dokumentácií.

Hlavným úmyslom prezentácie je oboznámenie širšej verejnosti s prácou archeológov, jej významom a dôležitostou. V súčasnej, technologicky orientovanej dobe, nie je adekvátne predpokladat, že prezentácia výsledkov v múzeu, kde je pri predmete malá popiska 


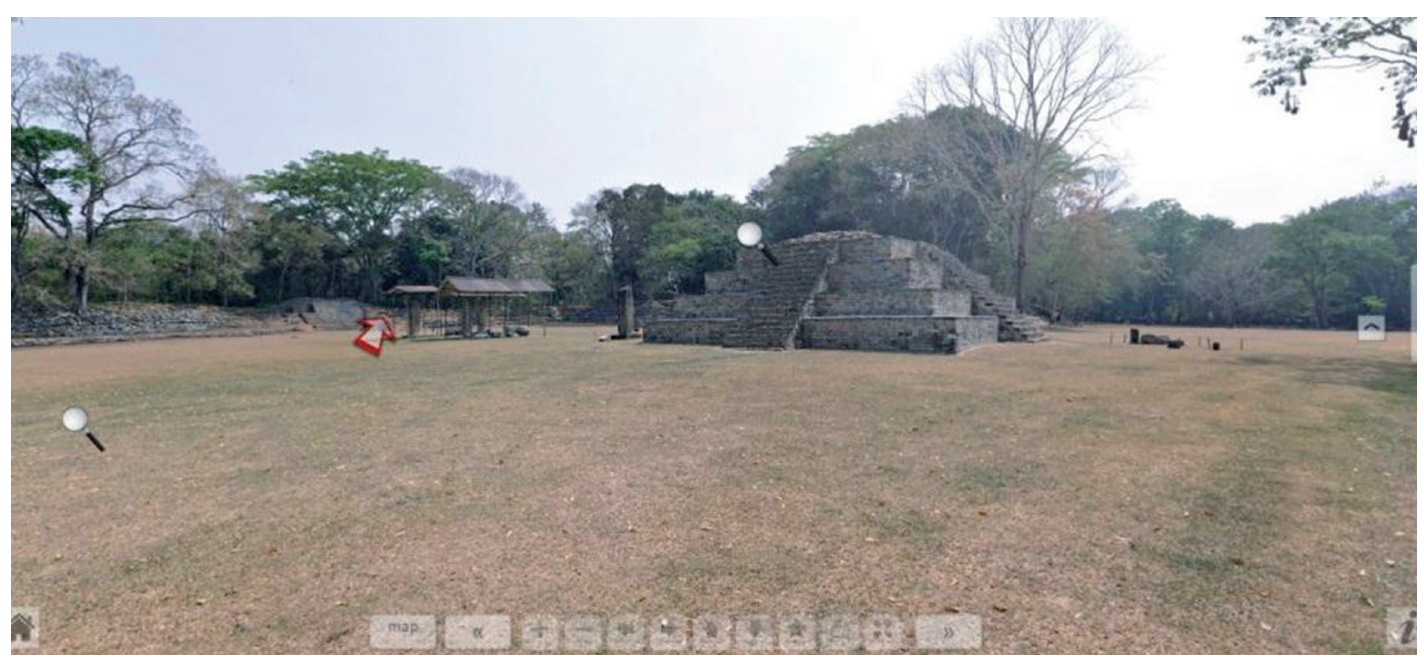

Obr. 31. Ukážka virtuálnej prehliadky v prostredí The MayaArch3D Project. Návštevník sa môže virtuálne prechádzat' celou lokalitou, približovat' si zaujímavé objekty a rovnako tak vidiet' 3D modely významných artefaktov (Kosmelová 2018, 76).

Fig. 31. Example of a virtual tour in the MayaArch3D Project. It is possible to have a virtual tour through the site, zoom to points of interest and examine 3D models of digitized artefacts (Kosmelová 2018, 76).

a v každej miestnosti sa nachádza vel'ké množstvo artefaktov je pre verejnost̉ dostačujúca. Takéto predmety dokážu zaujat skutočných nadšencov, no určite neoslovia vel'kú čast’ populácie a tak múzeá, ktoré neprichádzajú s inováciami strácajú na popularite. Trojrozmerné dáta, vizualizácia a virtuálna realita výrazne pomáhajú v popularizácií odboru. ${ }^{21}$ Takýto typ prezentácie je samozrejme velmi finančne aj časovo náročný. V súčasnej dobe môže byt aplikovaný bohužial' len pri dlhodobých a dobre finančne zaistených archeologických projektoch a výskumoch. Dôležitým predpokladom je otvorenost' bádatel’ov voči inováciám a diskusií o vol'be nových postupov. Ďalší spôsob, ako uplatnit nové postupy ponúkajú rôzne granty a sútaže. Pri vizualizácií a prezentácií je rozhodujúca forma, miesto a načasovanie, na čo tiež treba mysliet'.

Existuje vel'ké množstvo spôsobov prezentácie trojrozmerných dát. Najjednoduchšia publikácia je cez online 3D prehliadače digitálnych modelov. Za takýmto účelom vznikajú virtuálne múzea, v ktorých sú trojrozmerné modely vložené do virtuálnych galérii a pomocou klávesnice a myši je možné po pripojení na interne l'ubovol'né prehliadanie zo všetkých uhlov. ${ }^{22}$

Väčšina populácie ale stále preferuje osobný kontakt s predmetom, na ktorý môže reálne siahnut. Fyzický kontakt, alebo hmatový vnem je stále dôležitý a vd’aka nemu si l’udia dokážu lepšie uvedomit niektoré súvislosti. Pri prezentáciî artefaktov je väčšinou tento vnem nemožný, vzhladom na krehkost̉ alebo cenu predmetov. Možnost’ siahnut na predmet je v niektorých prípadoch umožnená vd’aka replikám, ktoré je však finančne pomerne náročné vyhotovit. Alternatívu predstavuje práve 3D tlač, kedy je možné artefakt neobmedzene duplikovat alebo vytlačit' v zmenšenej alebo zväčšsenej podobe.

Nakoniec by sme radi upozornili na niektoré zaujímavé projekty, ktoré sa zameriavajú na inovatívny spôsob prezentácie a vo svete 3D môžu byt vel'kou inšpiráciou. Jeden z najznámejších projektov spájajúci v sebe archeológiu, geografické informačné systémy, 3D dáta 
a virtuálnu realitu je už spomínaný The MayaArch3D Project. Konkrétne ide o 3D-GIS, ktorý integruje 3D modely miest, krajiny a objektov a prezentuje tak dôležité mesto mayskej civilizácie, Copán. ${ }^{23} \mathrm{Z}$ nášho prostredia nemôžeme opomenút český projekt Dwarf digital archeology, ktorý vytvára 3D vizualizácie, animácie a tiež virtuálnu realitu. ${ }^{24}$ Ďalej napríklad Historium Brugge, ktoré predstavuje moderný typ múzea, ktoré spojilo archeologické nálezy, historické správy a moderné technológie na prezentáciu stredovekých Brug. Múzeum vtahuje návštevníka pomocou špeciálnych efektov, virtuálnej reality a hudby do histórie príbehu tak, až má pocit, že ho sám prežil. ${ }^{25}$ The $3 D$ Giza Project umožňuje virtuálnu prehliadku 3D rekonštrukcie pyramíd v Gize a ich okolia. ${ }^{26}$ Nakoniec projekt, Rome Reborn, predstavuje kompletný model antického Ríma s rekonštrukciami významných budov a pamiatok, na vrchole jeho najväčšej slávy. ${ }^{27}$

\section{Záver}

Ciel’om predkladaného článku, ktorý v sebe spája archeológiu a výpočtovú techniku, bolo zdokumentovanie drobných archeologických predmetov súčasnými aj inovatívnymi metódami a ich následné porovnanie. V článku sa nachádza podrobný popis 4 dokumentačných techník: kresby, fotografie, 3D fotogrametrie a 3D skenovania a ich vybavenia, postupov a zhodnotenie náročnosti pre každú vybranú metódu.

Každá z popisovaných metód má svoje výhody ale aj nevýhody, a preto nie je možné dogmaticky prehlásit jednu z testovaných dokumentačných technik za jedinú správnu, ktorá by bola ultimátnym nástrojom, odpovedajúcim na všetky kladené otázky či požiadavky. Ako z našich záverov vyplýva, ideálnou cestou je prienik niekol'kých dokumentačných metód, ktoré pružne reagujú na náročnú výzvu, ktorou dokumentácia archeologického materiálu bezpochyby je. Pre docielenie požadovaného výsledku je vhodná ich vzájomná kombinácia doplňujúca prípadné slepé miesta, ktoré nie sú jednotlivé metódy schopné pokryt'.

Pre našu dokumentáciu drobných archeologických artefaktov vyšla jednoznačne najlepšie 3D fotogrametria. Na rozdiel od testovaného 3D skenera ponúka lepšie textúry, ktoré sú práve v archeológií, pri nemožnosti fyzického kontaktu s predmetom, velmi dôležité. Táto metóda vychádza tiež najlepšie čo sa týka pomeru ceny a výsledkov.

Treba však mat’ stále na pamäti, že akýkolvek záznam je len formou interpretácie a osoba vyhotovitel'a sa v ňom obyčajne prejaví, hoci aj len v malej miere. Pri procese kresby a fotografovania sa vo výsledku premietajú technické schopnosti, osobný prístup, ale aj odborný vhlad do tematiky, ktorá je spracovávaná. Pri trojrozmerných modeloch by sme mohli argumentovat' podobne, čo sa týka ludského zásahu počas jednotlivých krokov, no vel'kost̉ zásahu je maximálne potlačená na úkor presnosti technológie. Pri kresbe napríklad, vytvárame kresbu úplne nanovo, pričom pri 3D fotogrametrii je zásah tvorcu omnoho menší, čo činí 3D fotogrametriu omnoho dôveryhodnejšou. Čo sa však týka subjektivity a zásahu človeka, tie sú najmenšie pri 3D skenovaní.

Článok okrem trojrozmerných dát, ich vlastností a využití v archeológií pojednáva $\mathrm{v}$ krátkosti o možnostiach ich uskladnenia a tiež možnosti publikácie, alebo vizualizácie a prezentácie kultúrneho dedičstva. Na podporu popularizácie a prezentácie vlastnej práce boli vytlačené 3D modely šachových figúrok, podla technologickej špecifikácie popísanej v článku.

Na záver by sme radi dodali, že do budúcnosti majú trojrozmerné technológie určite čo ponúknut vd’aka rýchlo sa vyvíjajúcim technológiám. Moderná technika so svojou akcelerujúcou 
evolúciou s určitým oneskorením preniká tiež do archeológie a pamiatkovej starostlivosti a prináša nám početné možnosti, ako našu prácu zjednodušovat, inovovat a hlavne lepšie sprístupnit ako odborníkom, tak predovšetkým širokej verejnosti. Spomenieme napríklad hmatové rukavice Gloveone, ktoré by mohli činnost’ vo virtuálnom prostredí po zmyslovej stránke výrazne priblížit reálnej práci so skutočnými ar- tefaktmi. ${ }^{28}$ Tým by sa stali obrovským prínosom hlavne v archeológií, či už pri bádaní, alebo pri prezentácií našej činnosti.

Všetky komparované metódy majú svoj vel'ký potenciál, či už pre bádatel'ské použitie, alebo pre popularizačné. Je len na nás, ako dobre sme schopní ich využit a získané výstupy prezentovat širokej verejnosti, voči ktorej máme zodpovednost' za prezentáciu vedy.

1) Výsledky starších dát 3D fotogrametrie a 3D skenovania, ktoré sú porovnávané s novými dátami, sú k dispozícii od Mgr. Vojtěcha Noska (ÚArchMuz FF MU). Pre účel porovnania kresebnej dokumentácie boli k dispozícií staršie kresby od Lei Chatrnej (Muzeum města Brna), ktoré boli porovnávané s novými kresbami. Rovnako tak boli využité k porovnaniu nových fotografií staršie fotografie od Mgr. Šimona Kochana (ÚArchMuz FF MU) z roku 2013, ktoré sú tiež použité pri hodnotení degradácie figúrok.

2) Rada programov ponúka svojim potencionálnym užívatelom vel'ké množstvo edícií a typov licencií, ktoré potom dovolujú jeden program zaradit do viacerých kategórií. Rozradenie programov tak nie je možné chápat dogmaticky, ale slúži len na ukážku.

3) Programy sa rýchlo vyvíjajú a s nimi sa môžu menit aj ich licenčné podmienky. Prípadne jeden program môže byt dostupný vo viacerých verziách, z ktorých si môže používatel’ vybrat’ jemu používatelsky najviac vyhovujúcu variantu.

4) Prekonanie fragmentárnosti alebo viacero možnosti interpretácií by mnoho bádatelov mohlo označit aj za možnú nevýhodu. Mnoho z nich sa opiera len o fakty a možné vizuálne interpretácie striktne oddelujú od reálnej vedy.

5) Pri popise skúsenosti s prácou s 3D skenermi vychádzame z ústnych informácií Mgr. Mikoláše Jurdy, Ph.D (ÚAntr Biol PřF MU) a Mgr. Vojtěcha Noska.

6) Za ústnu informáciu dakujem Mgr. Petrovi Holubovi (Múzeum města Brna) a Mgr. Pavlovi Staňkovi (Archaia z.ú.). Na inventári z výskumu na Panenskej ulici pracuje Múzeum mesta Brna, a bohužial v súčasnosti nie je ešte dostupná nálezová správa.

7) Pre zváženie figúrok bola použitá kuchynská váha značky Emos TY3101B, ktorá váži s presnostou na 1 gram a na meranie bola využita šubléra, pravítko a krajčírsky meter.

8) Kresebná dokumentátorka na ÚArchMuz FF MU.

9) Makro krúžok umožňuje zaostrit na objekt z menšej vzdialenosti, vd’aka čomu vieme vytvorit detailnejší záber, avšak kvôli zväčšeniu vzdialenosti objektívu od tela fotoaparátu dochádza k úbytku svetla, ktoré sa dostáva na snímač fotoaparátu.

10) Presný postup editácie je popísaný v bakalárskej práci autorky (Kosmelová 2018, 46-47).

11) Napríklad grécka keramika s malovanou zoomorfnou výzdobou (Boardman 1998, 125).

12) Pre kresbu to bola Mgr. Soňa Plchová (ÚArchMuz, FF, MU), pre 3D fotogrametriu Mgr. Vojtěch Nosek (ÚArchMuz, FF, MU) a pre 3D skenovanie Mgr. Mikoláš Jurda, Ph.D. (ÚAntr - Biol, PřF, MU).

13) Modely boli k dispozícií od Mgr. Vojtěcha Noska.

14) https://www.danielgm.net/cc/.

15) Zoznam aktuálnych 3D formátov dostupný na https://fileinfo.com/filetypes/3d_image.

16) Posledná z nich však nedokáže niest̉ textúru.

17) The MayaArch3D Projekt vyvinul open source program v ktorom sú testované 4 nástroje umožňujúce skladovat', upravovat', analyzovat a vizualizovat dáta rôznych formátov a rozlíšenia, slúžiace zatial ako prototypy (Reindel Isla - Otten - Gorbahn - Schwerin 2014).

18) Ako príklad straty velkého množstva predmetov a výsledkov z výskumu uvedieme rozsiahly požiar v Mikulčiciach z roku 2007, kedy boli nenávratne zničené nielen cenné predmety z depozitára, ale aj celá dokumentácia pätdesiatročného výskumu, ktorý tým pádom akoby vôbec ani neprebehol. Je nutné dodat, že prehliadanie akútne zlého stavu budovy stálo život strážnika.

19) Ako príklad je možné uviest̉ nový projekt Akadémie vied ČR Švédská knižní kořist z Čech a Moravy 1646-1648, zameriavajuci sa na katalogizáciu a digitalizaciu dokumentov odcudzených z Čiech behom Tridsatročnej vojny (https://www.knizni-korist.cz/). 
20) Pre príklad opät uvedieme zaujímavý projekt The Maya Music Project, ktorý výrazne pomáha pri skúmaní hudobných nástrojov v mayskej civilizácií. Väčšina nálezov je umiestnená v múzeách, zbierkach a laboratóriách naprieč celou Mezoamerikou, čo neskutočne stažuje skúmanie a prípadné porovnávanie artefaktov z rôznych zbierok činí skoro nereálnym (Katz 2016, 31). Výskumník by potreboval množstvo povolení pre špeciálny prístup do rôznych inštitúcií, cestovat’ do rôznych lokalít a manuálne by musel v každej inštitúcií prechádzat̉ zbierky, pretože nástroje môžu byt zaradené v rôznych kolekciách. Vd’aka projektu má prístupné 3D modely, ktoré si prípadne môže vytlačit.

21) Opät by sme radi demonštrovali na príklade projektu The Maya Music Project (Katz 2017, 36), počas ktorého boli študentom rozdané repliky hudobných nástrojov, o ktorých si mali dohladat všetky dostupné archeologické informácie a vo výsledku ich mali odprezentovat’ svojim spolužiakom aj s pokusom o zahranie na daný artefakt. Tento projekt dosiahol medzi študentmi $80 \%$ úspešnost́ pri učení sa o hudobných artefaktoch mayskej civilizácie a 87\% úspešnost’ pri popularizácií a záujme o archeológiu (Katz 2017, 36).

22) Napríklad Archeologické 3D virtuálne múzeum (http://www.archaeo3d.com/virtualni-muzeum/).

23) Viac informácií o projekte na https://mayaarch3d.org/en/.

24) Viac informácií o projekte na https://www.dwarfdigital.cz/index.php/archeologie/.

25) Viac informácií o projekte na https://www.historium.be/en.

26) Viac informácií o projekte na http://giza.fas.harvard.edu/.

27) Viac informácií o projekte na https://www.romereborn.org/.

28) Viac informácií na https://avatarvr.es/.

\section{Obrazová príloha}
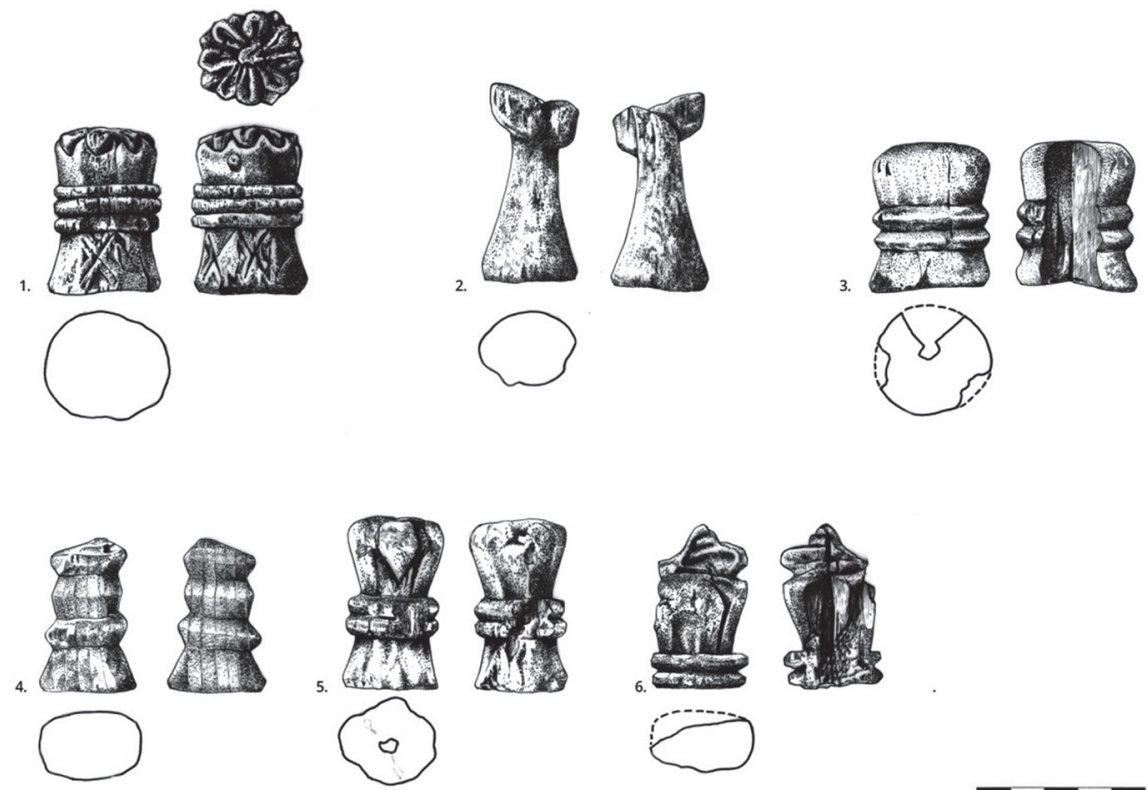

Obr. 32. Staršia kresebná dokumentácia šachových figúrok. Upravená tabul'ka kvôli potrebe zjednotenia číslovania. Kresba: L. Chatrná (Kosmelová 2018, 101).

Fig. 32. Old drawing of chess pieces. Plate has been edited according to need of unified of numbering of chess pieces. Drawing: L. Chatrná (Kosmelová 2018, 101). 


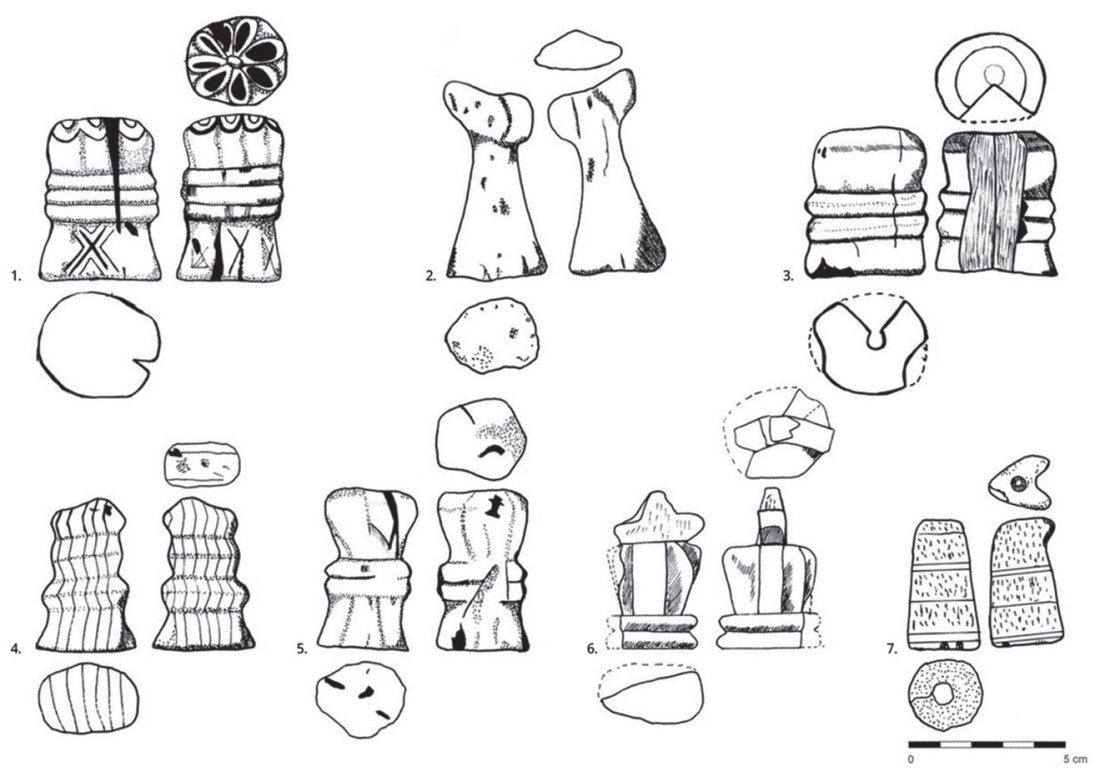

Obr. 33. Nová kresebná dokumentácia šachových figúrok. Kresba: N. Kosmelová (Kosmelová 2018, 102).

Fig. 33. New drawing of chess pieces. Drawing: N. Kosmelová (Kosmelová 2018, 102).
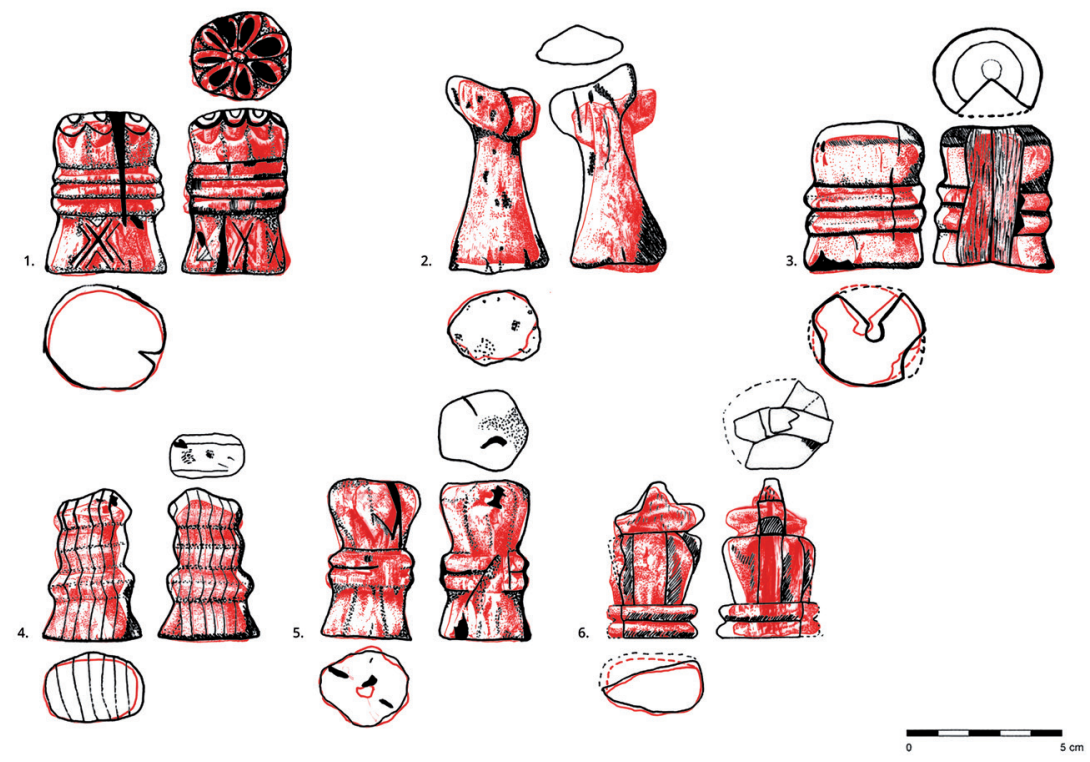

Obr. 34. Subjektivita dvoch kresebných dokumentátorov a chyby vzniknuté pri meraní artefaktov. Viditel'né rozdiely v skúsenostiach dokumentátorov. Zdroj: N. Kosmelová 2018.

Fig. 34. Subjectivity of two drawers and the artefact measurement errors. Visible differences in the expertise of individual drawers. Source: N. Kosmelová 2018. 
1.

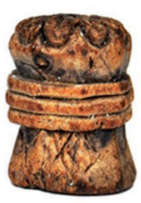

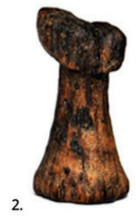

3.

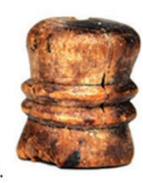

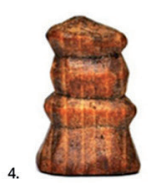
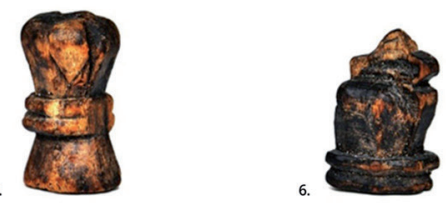

Obr. 35. Upravená tabul'ka staršej fotografickej dokumentácie pre potrebu zjednotenia číslovania figúrok. Foto: Š. Kochan.

Fig. 35. A plate with older documentary photos modified for the needs of a unified numbering of chess pieces. Photo: Š. Kochan.
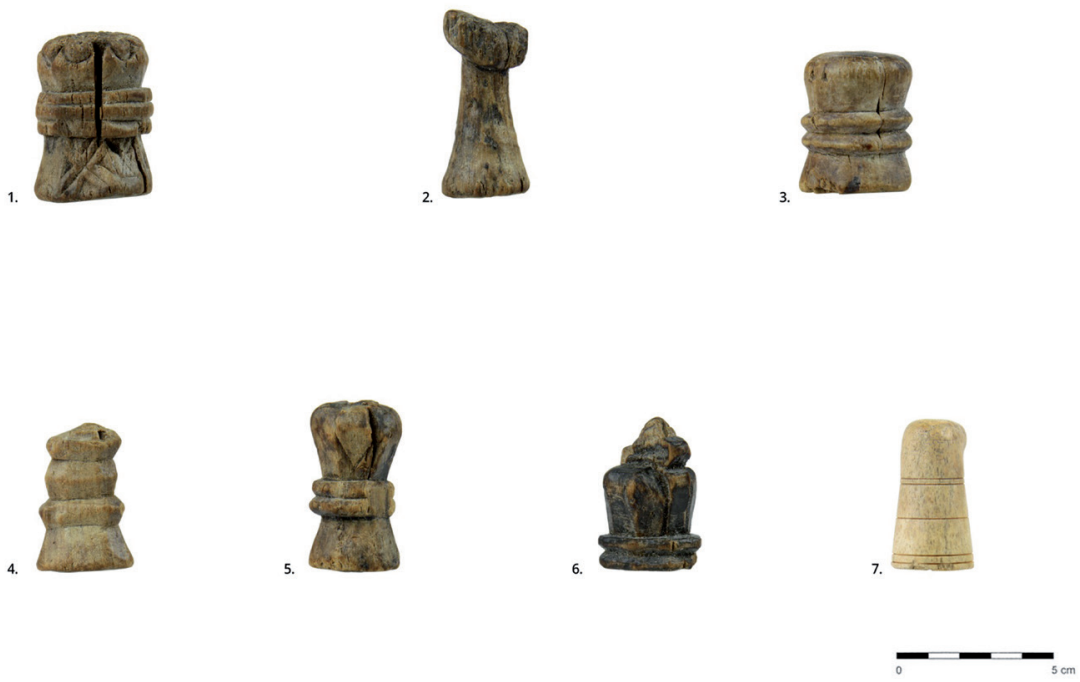

Obr. 36. Nová fotografická dokumentácia šachových figúrok. Foto: N. Kosmelová.

Fig. 36. New photographic documentation of chess pieces. Photo: N. Kosmelová. 


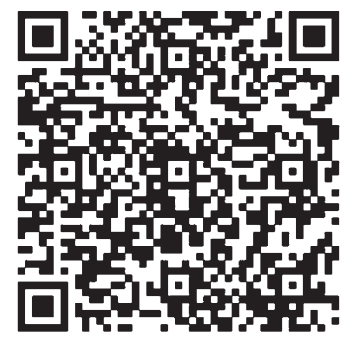

FIGÚRKA Č. 1.

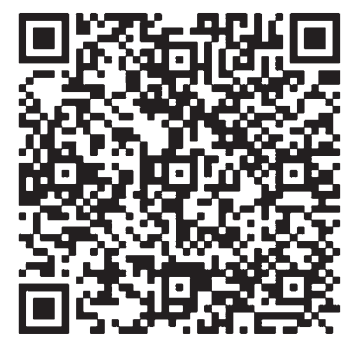

FIGÚRKA Č. 3.

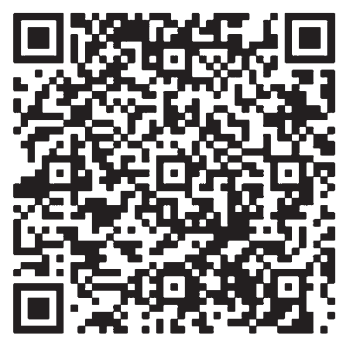

FIGÚRKA Č. 5.

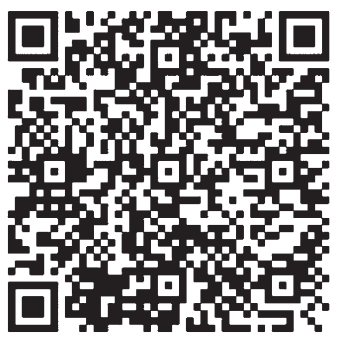

FIGÚRKA Č. 2.

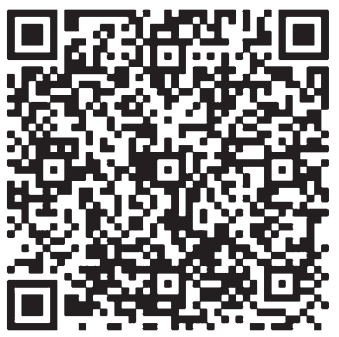

FIGÚRKA Č. 4.

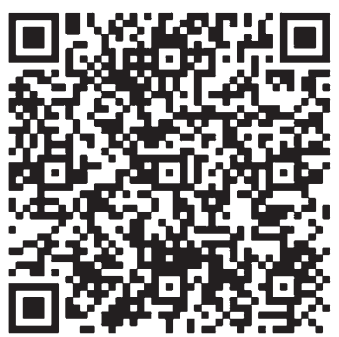

FIGÚRKA Č. 6.

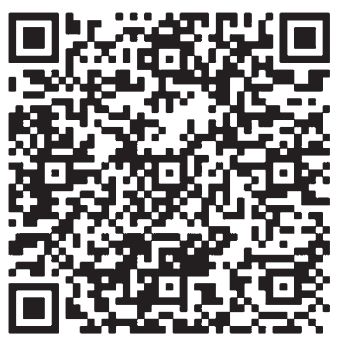

FIGÚRKA Č. 7.

Obr. 37. Vygenerované QR kódy pre 3D modely získané pomocou 3D fotogrametrie (Kosmelová 2018, 105).

Fig. 37. QR codes for 3D models acquired by 3D photogrammetry (Kosmelová 2018, 105). 


\section{Použitá literatúra a zdroje}

Boháč, O. 2014: Optické korelační systémy - průzkum a zhodnocení aktuálního stavu. Rukopis diplomové práce uloženej v ČVUT, FSv, obor Geodézie a kartografie, vedoucí práce Ing. Jindřich HODAČ, Ph.D. Praha.

Boardman, J. 1998: Early Greek Vase Painting, Londýn: Thames and Hudson.

Frank, R. - Kriesberg, A. - Yakel, E. - Faniel, I. 2015: Looting hoards of gold and poaching spotted owls: data confidentiality among archaeologists \& zoologists. Proc. Assoc. Inf. Sci. Technol. 52 (1), $1-10$.

Frouz, M. - Králík M. 2015: Fotografie v biologické antropologii. Brno.

Gilboa, A. - Kolomenkin, M. - Tal, A. - Shimshoni, I. 2013: Computer-based, automatic recording and illustration of complex archeological artifacts. In: Hunt, C. O. - Klein, R. G. - Rehren, Th. - Torrence, R. (eds.): Journal of Archaeological Science 40, 1329-1339.

Gruen, A. 2008: Image-based 3D recording and modeling of landscapes and large Cultural Heritage sites. In: Training Seminars on Research Planning, Conservation, Characterization and Management in Archaeological Sites. Bologna.

Griffiths, N. - Jenner, A. - Wilson, Ch. 1990: Drawing Archaeological Finds. Salisbury.

Johnson, J. S. 1994: Consolidation of Archaeological Bone. Journal of Field Archaeology 21, 221-233.

Karasik, A. - Smilansky, U. 2008: 3D scanning technology as a standard archaeological tool for pottery analysis: practice and theory. Journal of Archaeological Science 35/5, 1148-1168.

Kasser, M. - Egels, Z. 2002: Digital Photogrammetry. New York.

Katz, J. 2016: The Maya Music Project: Analaysis and documentation of ancient Mayamusical artifacts. Studien Zur Musikarchäologie X, 257-261.

Katz, J. 2017: Digitized Maya Music: The creation of a 3D database of Maya musical artifacts. Digital Applications in Archaeology and Cultural Heritage 6, 29-37.

Kenney, A. R. - Rieger, O.Y. 2000: Moving theory into Practice. Digital imaging for libraries and archives. Mountain View. RLG.
Kochan, Š. 2014: Nálezový soubor ze středověké studny benediktinského proboštství v Brně Komárově. Rukopis diplomové práce uloženej v ÚAM FF MU Brno, vedoucí práce Mgr. Jana Mazáčková, Ph.D. Brno.

Kochan, Š. - Sedláčová, H. - Vachůt, P. 2015: Nálezový soubor ze středověké studny benediktinského proboštství v Brně-Komárově. Pravěk NŘ 23, 231-287.

Kosmelová, N. 2018: Aplikácia inovatívnych metód dokumentácie drobných archeologických artefaktov. Rukopis diplomovej práce uloženej na ÚAM FF MU Brno, vedúci práce Mgr. Vojtěch Nosek. Brno.

Kuna, M. 2004: Nedestruktivní archeologie: Teorie, metody a cíle. Praha.

Král, M. 2010: Adobe Photoshop Lightroom 2. Praha.

Malina, O. 2008: Poznámky k možnostem 3D rekonstrukcí v archeologii, In: Macháček, J. (ed.): Počítačová podpora $\mathrm{v}$ archeologii 2. Brno - Praha - Plzeň, 212-216.

Navrátil, R. 2016: Technologie skenování ve 3D [online, e-skripta]. [cit. 2018-06-26]. Dostupné z: http:// www.spsks.cz/wp-content/uploads/2016/03/ Technologie-skenov\%C3\%A1n\%C3\%AD-ve-3D-0. pdf_

Neustupný, E. 2007: Metoda archeologie. Plzeň.

Nosek, V. 2014: Srovnání možností 3D fotogrammetrie a 3D skeneru při dokumentaci archeologických artefaktů. Rukopis diplomovej práce uloženej na ÚAM FF MU Brno. Vedúci práce Mgr. Dagmar Vachůtová, Ph.D. Brno.

Orton, C. - Tyers, P. - Vince, A. 1993: Pottery in Archaeology. Cambridge.

Plzák, J. 2016: Moderní dokumentační metody archeologických faktů, rkp. Dizertačnej práce uloženej na Západočeskej univerzite v Plzni.

Págo, L. 1985: Úvod do muzejní konzervace a restaurování. Skripta FF UJEP, Brno.

Porter, S. - Roussel, M. - Soressi, M. 2016: A Simple Photogrammetry Rig for the Reliable Creation of 3D Artifact Models in the Field: Lithic Examples from the Early Upper Paleolithic Sequence of Les Cottés (France). Advances in Archaeological Practice, 4(1), 71-86.

Reindel, M. - Isla, J. - Otten, H. - Gorbahn, H. Schwerin, J. 2014: Archäologische Forschungen 
in Peru und Honduras im Jahr 2013. Zeitschrift für Archäologie Außereuropäischer Kulturen 6, 289-308.

Richards-Rissetto, H. - Schwerin, J. 2017: A Catch 22 of 3D Data Sustainability: Lessons in 3D Archaeological Data Management \& Accessibility. Journal of Digital Applications in Archaeology and Cultural Heritage 6, 38-48.

Smith, C. W. 2003: Archaeological Conservation Using Polymers: Practical Applications for Organic Artifact Stabilization. College Station.

Skopec, R. 1956: Fotografie v našich službách. Praha.

Švejnoha, J. 2010: Fotogrametrická dokumentace archeologických terénních výzkumů. Acta Fakulty Filozofické Západočeské univerzity v Plzni 1, 109-117.

Valoch, K. - Lázničková-Galetová, M. 2009: Nejstarší umění střední Evropy. Brno.

Zelinger, J. - Šimůnková, E. - Kotlik, P. 1982: Chemistry in Work of the Conservator. Academia, Praha.

Wilczek, J. a kol. Prostorová dokumentace artefaktů a vytváření 3D modelů [online, rozpracovaná e-skripta]. [cit. 2018-06-26]. Dostupné z: https://elf.phil.muni.cz/elf3/mod/folder/view. php?id=159222

\section{Zoznam použitých internetových odkazov}

Projekt Akadémie vied ČR Švédská knižní kořist z Čech a Moravy 1646-1648. https://www.knizni-korist.cz/

Platforma na ktorej sú uložené 3D modely. https:/ / sketchfab.com/eNKa44

Cloud Compare. https://www.danielgm.net/cc/

Archeologické 3D virtuálne múzeum.

http://www.archaeo3d.com/virtualni-muzeum/

Ukážka virtuálnej prehliadky v prostredí The Maya-

Arch3D Project. http://3dom.fbk.eu/repository/

files/vt_copan/index-EN.html

Odkaz na oficiálne stránky Maya Arch 3D. http:// www.mayaarch3d.org/language/en/sample-page/

Odkaz na oficiílne stránky Dwarf digital. https:// www.dwarfdigital.cz/index.php/archeologie/

Odkaz na oficiálne stránky Historium Brugge.

https://www.historium.be/en

Odkaz na oficiálne stránky The 3D Giza Project.

http://giza.fas.harvard.edu/

Odkaz na oficiálne stránky Rome Reborn. https:// www.romereborn.org/

Hmatové rukavice Gloveone. https://avatarvr.es/

Zoznam 3D formátov. https://fileinfo.com/filetypes/3d_image 


\section{Digital and analogue documentation approaches in archaelogy: Chess pieces as a case study}

The article is based on the still unpublished Bachelor's thesis by Natália Kosmelová. Thematic focus is laid on the methods of documentation of archaeological artefacts with emphasis on the comparison of standard documentation techniques and innovative digitisation approaches, such as 3D scanning or photogrammetry. Their use is studied from the perspective of technical difficulty, time demands and applicability to diverse archaeological material. The article is also extended by the evaluation of benefits of these new approaches from the viewpoint of their use as a promotion tool and improvement of accessibility of unique artefacts to general public.

Standard documentation methods used with archaeological artefacts are drawing and photographing. New digital methods include 3D scanning (3D scanners used: Mephisto EOSScan and NextEngine) and photogrammetry (software used: 3D Software Object Modeler and Agisoft Photoscan Pro). All these approaches were applied to a reference set of prestigious artefacts - seven high medieval chess pieces from the territory of Brno. Six wooden pieces come from excavations of the Benedictine Provostry in Komárov and the last piece is made from bone and comes from excavations in the Panenská Street. All tested methods proved suitable for documentation of these materials and confirmed the necessity of a complex documentation of artefacts, which despite conservation suffer from degradation of their structure and morphology.
The evaluation of applicability and demands of individual methods was conducted by the authors in the form of personal observation. All approaches were evaluated for the necessary equipment, staff competence, time and financial demands, fidelity of the result compared to the original, achieved accuracy, possible subjective influence on the result, and the possibility of using the result for subsequent scientific analysis.

The article describes both the elaborated and applied documentation methods, and the knowledge based on the authors' empiricism and personal observation. It also comprises a list of technical equipment, appliances and their technical parameters. The documentation results are partly attached as pictorial supplements and partly published online on the Sketchfab 3D visualisation platform. Emphasis is also put on criticism of older results of 3D documentation, which were acquired by the authors in 2012 and 2014 using the methods available at that time. It is evident that the progressive development of this documentation branch should be monitored and reflected as quickly as possible to document artefacts with the best suitable and best possible method. Standard methods like drawing or photographing of course cannot yet be left out from the documentation process, but the possibilities of new digitisation methods must be used. Besides their great visualisation and popularisation potential, they also offer a large space for scientific analysis in the field of morphological and archaeometric studies of artefacts.

\section{Bc. et Bc. Natália Kosmelová}

- Ústav archeologie a muzeologie,

Filozofická fakulta, Masarykova univerzita,

A. Nováka 1, 60200 Brno, Česká republika

428255@mail.muni.cz
Mgr. Vojtěch Nosek

- Ústav archeologie a muzeologie, Filozofická fakulta, Masarykova univerzita, A. Nováka 1, 60200 Brno, Česká republika 330862@mail.muni.cz 